\title{
BIOLOGIA E EXIGÊNCIAS TÉRMICAS DE Tuta absoluta (Meyrick, 1917) EM DIETA ARTIFICIAL
}

\section{LAILA HERTA MIHSFELDT}

Tese apresentada à Escola Superior de Agricultura "Luiz de Queiroz"; Universidade de São Paulo, para obtenção do título de Doutor em Ciências, Área de Concentração: Entomologia.

\author{
PIRACICABA \\ Estado de São Paulo - Brasil \\ Junho - 1998
}




\title{
BIOLOGIA E EXIGÊNCIAS TÉRMICAS DE
}

\author{
Tuta absoluta (Meyrick, 1917) \\ EM DIETA ARTIFICIAL
}

\author{
LAILA HERTA MIHSFELDT
}

Engenheiro Agrônomo

Orientador: Prof. Dr. JOSÉ ROBERTO POSTALI PARRA

Tese apresentada à Escola Superior de Agricultura "Luiz de Queiroz", Universidade de São Paulo, para obtenção do titulo de Doutor em Ciências, Área de Concentração: Entomologia.

PIRACICABA

Estado de São Paulo - Brasil

Junho - 1998 
BIOLOGIA E EXIGÊNCIAS TÉRMICAS DE Tuta absoluta (MEYRICR, 1917) EM DIETA ARTIFICIAL

LAILA HERTA MIHSFELDT

$$
\text { Prof. Dr. JOSÉ ROBERTO POSTALI PARRA }
$$
Orientador 
A meus pais,

\title{
GUILHERME E ELSBETH,
}

\author{
pela vida, pela eterna compreensão e pelo amor \\ seguro e constante,
}

OFEREÇO

Às minhas irmãs,

\section{LISE E FERNANDA,}

como prova de que sonhar é preciso, vencer é possível, com todo carinho e admiração, 


\section{AGRADECIMENTOS}

Ao Dr. José Roberto Postali Parra, Professor Associado do Departamento de Entomologia da ESALQ/USP, Piracicaba-SP, pela orientação segura, apoio e confiança na condução deste trabalho;

\section{A Fundação Faculdade de Agronomia "Iuiz} Meneghel", na pessoa de seu Diretor Prof. Luiz Carlos Reis, pelo apoio e oportunidade de realizar o Curso;

Ao Dr. José Celso Martins, chefe do Departamento de Fitotecnia da FFALM, pela amizade, apoio e facilidades oferecidas para a finalização do presente trabalho;

À Professora Maria Apparecida Valério, pelo auxílio nas análises estatísticas e, especialmente, pela amizade, apoio e incentivo durante todas as etapas do trabalho realizado;

A Fundação CAPES [Fundação Coordenação de Aperfeiçoamento de Pessoal de Nível Superior] pela concessão da bolsa de estudo durante o curso;

A Secretaria de Ciência e Tecnologia do Estado de são Paulo, pelo suporte financeiro para a realização do presente trabalho;

Aos Professores do Departamento de Entomologia da ESAIQ/USP, pelos ensinamentos, amizade e apoio recebidos.

A Neide Graciano Zério funcionária do laboratório de Biologia de Insetos, do Departamento de Entomologia da ESALQ/USP, pelo auxílio nos trabalhos e, especialmente, pela amizade; 
Aos Engenheiros Agrônomos. Aline de Holanda Nunes Maia e Alfredo José Barreto Luiz, da EMBRAPA-CNPMA, pelo auxílio na análise estatística das tabelas de vida;

Ao biólogo Heraldo Negri de Oliveira funcionário do Departamento de Entomologia da ESALQ/USP, pelo auxílio nos trabalhos fotográficos e amizade;

Aos amigos de "república", Alexandre, Ana Carmem, Claudinho, Josué, Leandro, Marcílio, Marcos Botton e, especialmente, à Mírian, pela convivência agradável, amizade, companheirismo e carinho recebido;

Aos amigos Ana Maria, Antonio Rogério (Pakú), César, Crébio, Eliana, Marta, Mauro, Milanez e Rosmarina, pela amizade e agradável convivência;

Aos amigos de Bandeirantes Cidinha, Cristina, Débora, Ivana, Ivania, Maristela, Pelé e, em especial, para Nina, pelo incentivo constante, carinho sincero e amizade leal.

E a todos que direta ou indiretamente auxiliaram na condução e finalização do presente trabalho. 


\section{SUMÁRIO}

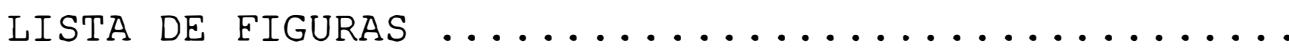

Página

LISTA DE TABELAS

vii

ix

RESUMO

xii

SUMMARY

$\mathrm{xiv}$

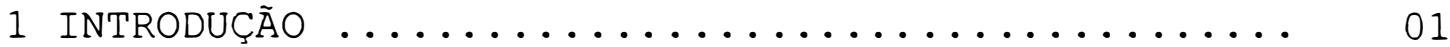

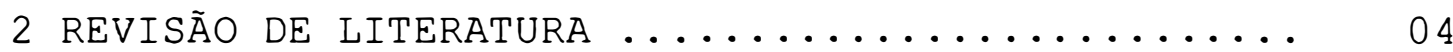

2.1 Distribuição geográfica e hospedeiro ......... 04

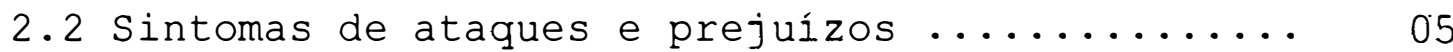

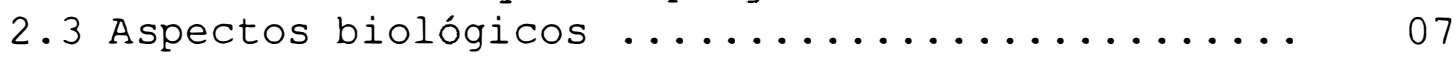

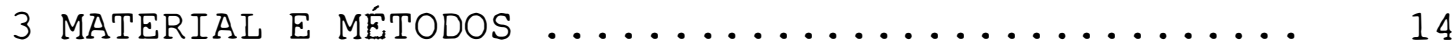

3.1 Biologia comparada de Tuta absoluta (Meyrick,

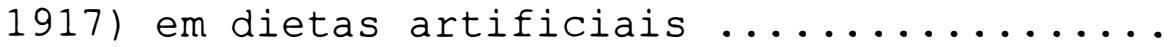

3.2 Determinação do número ideal de lagartas de $T$.

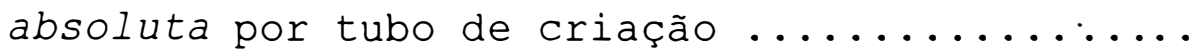

3.3 Biologia da traça-do-tomateiro em diferentes

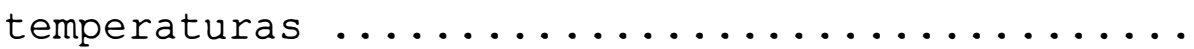

3.4 Determinação das exigências térmicas e número

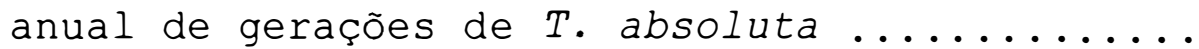

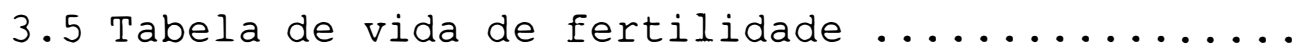

3.6 Local alternativo de postura de T. absoluta...

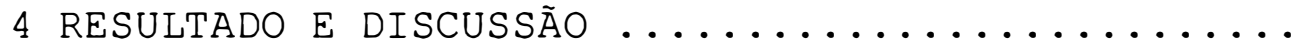

4.1 Biologia comparada de Tuta absoluta (Meyrick,

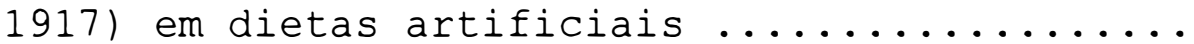

4.2 Determinação do número ideal de lagartas de T.

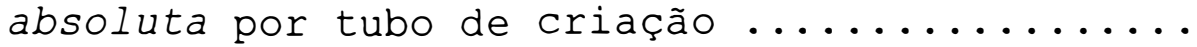

4.3 Biologia da traça-do-tomateiro em diferentes

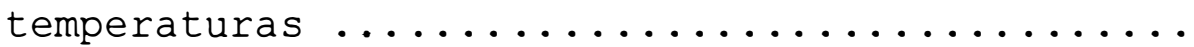

4.4 Determinação das exigências térmicas e número

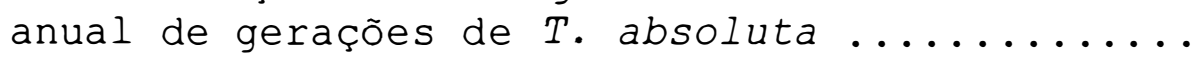

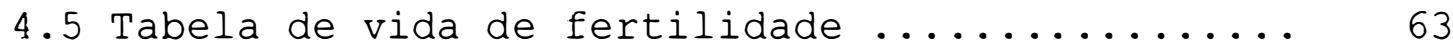

4.6 Local alternativo de postura de T. absoluta ... 70

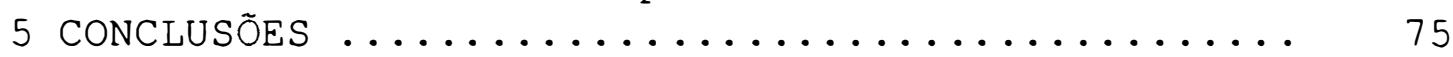

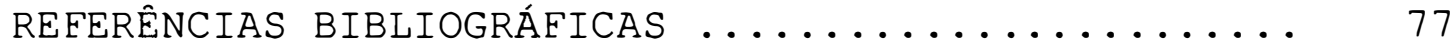




\section{IISTA DE FIGURAS}

1 Técnica de criação de T. absoluta em dieta artificial. A - Lagarta de T. absoluta em dieta artificial; B - Aspecto da dieta artificial utilizada para a criação de T. absoluta em tubo

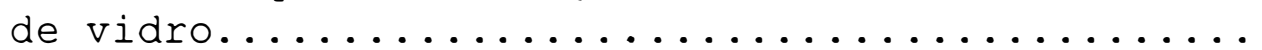

2 Pupas de T. absoluta sobre algodão em tubos de dieta artificial (A). Detalhes das pupas dentro

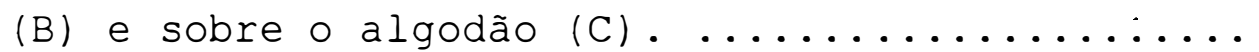

Página

3 Tubo de vidro para avaliar a capacidade de postura de T. absoluta. A - Tubo de vidro contendo internamente recipiente menor com água e algodão e foliolo de tomateiro; B - Casal de $T$.

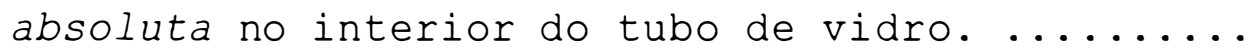

4 Tratamentos estudados como local alternativo de postura de T. absoluta (A_F). A- Copo plástico + papel sulfite + extrato de folha de tomateiro; BCopo plástico + papel sulfite + polietileno verde + extrato de folha de tomateiro; C- Copo plástico + papel sulfite + polietileno verde + fatia de fruto do tomateiro; D-, Copo plástico + papel sulfite + fatia do fruto do tomateiro; E- Copo plástico + papel sulfite; F- Copo plástico + foliolo do tomateiro; G- Detalhe da fatia do fruto do tomateiro colocado sob o papel de

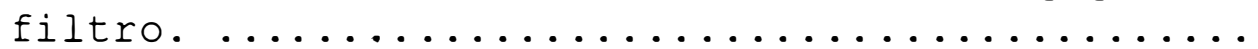

5 Sobrevivência de machos de T. absoluta em 8 dietas artificiais e em dieta natural. Valores observados e estimados pela equação de Weibull T:

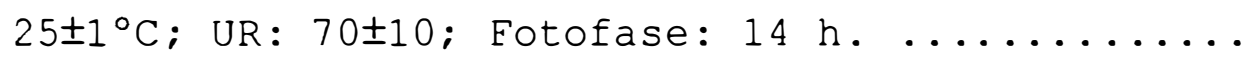

6 Sobrevivência de fêmeas de T. absoluta em 8 dietas artificiais e em dieta natural. Valores observados e estimados pela equação de Weibull. $\mathrm{T}: 25 \pm 1{ }^{\circ} \mathrm{C}$; UR: $60 \pm 10$; Fotofase: $14 \mathrm{~h} . \ldots \ldots \ldots . .$.

7 Curva de distribuição de freqüência de larguras de cápsulas cefálicas de T. absoluta criada em 6 dietas artificiais. As setas indicam os instares.

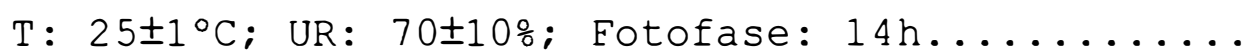

8 Curva de distribuição de freqüência de larguras de cápsulas cefálicas de T. absoluta criada em 2 dietas artificiais e em dieta natural. As setas indicam os instares. T:25 $\pm 1^{\circ} \mathrm{C} ; \mathrm{UR}: 70 \pm 10 \%$; Fotofase: $14 \mathrm{~h}$. 
9 Sobrevivência de machos de T. absoluta criados em dieta artificial e em diferentes temperaturas. Valores observados e estimados pela equação de

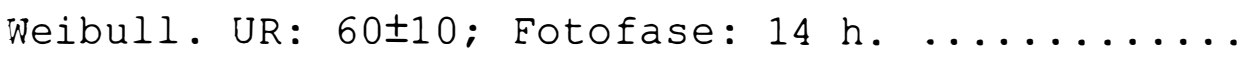

10 Sobrevivência de fêmeas de $T$. absoluta em dieta artificial e em diferentes temperaturas. Valores observados e estimados pela equação de Weibull.

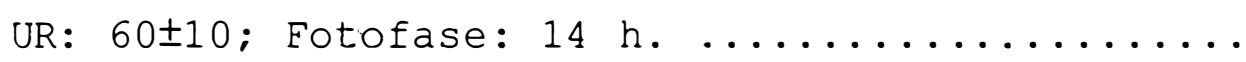

11 Curva de velocidade de desenvolvimento de $T$. absoluta criada em dieta artificial, em diferentes

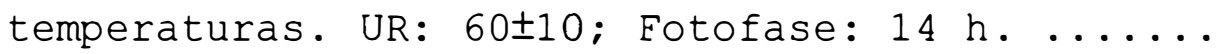

12 Taxa liquida de reprodução (Ro) de T. absoluta criada em 8 dietas artificiais e em dieta natural. As barras $(\perp$ e $T)$ representam 0 intervalo de confiança de 95\%. T: $25 \pm 1{ }^{\circ} \mathrm{C}$; UR:

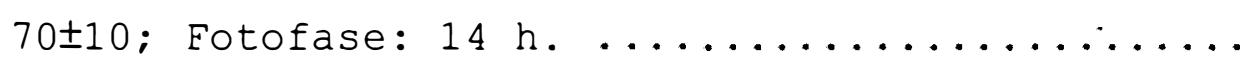

13 Razão infenitesimal de aumento ( $\mathrm{rm}$ ) de $T$. absoluta criada em 8 dietas artificiais e em dieta natural. As barras ( $\perp$ e T) representam 0 intervalo de confiança de 95\%. T: $25 \pm 1^{\circ} \mathrm{C}$; UR:

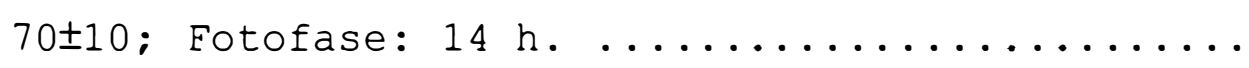

14 Intervalo médio entre gerações $(\mathrm{T})$ de $T$. absoluta criada em 8 dietas artificiais e em dieta natural. As barras $(\perp$ e $T)$ representam 0 intervalo de confiança de 95\%. T: $25 \pm 1^{\circ} \mathrm{C}$; UR:

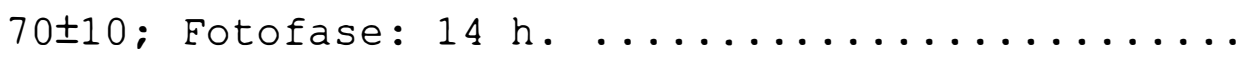

15 Razão finita de aumento populacional $(\lambda)$ de $T$. absoluta criada em 8 dietas artificiais e em dieta natural. As barras $(\perp$ e $T)$ representam 0 intervalo de confiança de 95\%. T: $25 \pm 1^{\circ} \mathrm{C}$; UR:

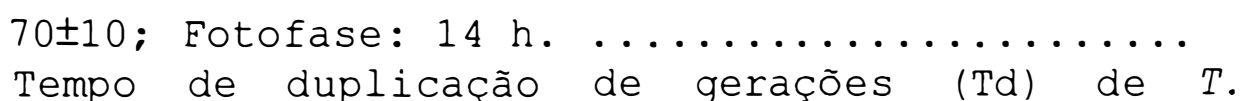

16 Tempo de duplicação de gerações (Td) de T.
absoluta criada em 8 dietas artificiais e em dieta natural. As barras ( $\perp$ e T) representam o intervalo de confiança de 95\%. T: $25 \pm 1^{\circ} \mathrm{C}$; UR:

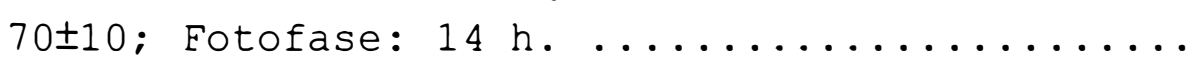




\section{IISTA DE TABELAS}

1 Composição da dieta modificada de Greene et al.

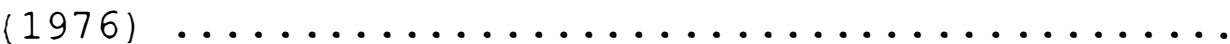

Página

2 Locais de postura testados para $T$. absoluta em

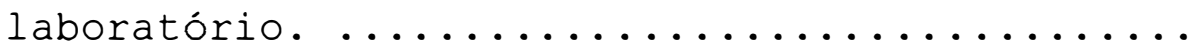

3 Duração dos períodos larval e pupal e peso de pupas de Tuta absoluta em 8 dietas artificiais e em dieta natural. Temperatura: $25 \pm 1{ }^{\circ} \mathrm{C}$; UR:

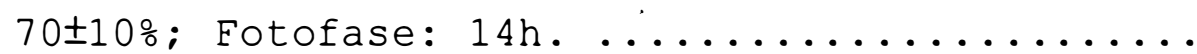

4 Durações dos período łarval e pupal e peso de pupas de fêmeas de Tuta absoluta em 8 dietas artificiais e em dieta natural. Temperatura:

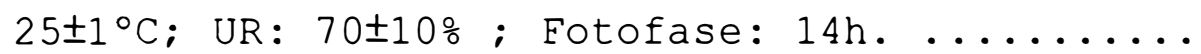

5 Durações dos período larval e pupal e peso de pupas de machos de Tuta absoluta criada em dieta artificial. Temperatura: $25 \pm 1{ }^{\circ} \mathrm{C}$; UR:

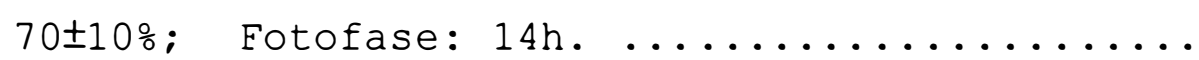

6 Número médio de ovos colocados por Tuta absoluta criada em 8 dietas artificiais. Temperatura: $25 \pm 1^{\circ} \mathrm{C}$; UR: $70 \pm 10 \%$ Fotofase:

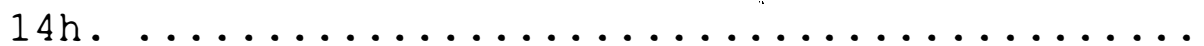

7 Razão sexual e longevidade média de machos e fêmeas de $T$. absoluta criados em 8 dietas artificiais e em dieta natural. Temperatura: $25 \pm 1{ }^{\circ} \mathrm{C}$; UR: $70 \pm 10 \%$; Fotofase: $14 \mathrm{~h} . \ldots \ldots \ldots . .$.

8 Viabilidade das fases larval, pupal, total e porcentagem de adultos não emergidos e deformados obtidos nas diferentes dietas artificiais. Temperatura: $25 \pm 1^{\circ} \mathrm{C}$; UR: $70 \pm 10 \%$;

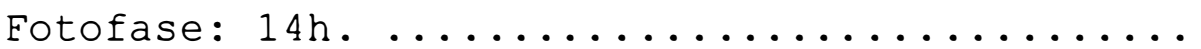

9 Largura média da cápsula cefálica e razão de crescimento de $T$. absoluta criada em 8 dietas artificias em dieta natural. Temperatura: $25 \pm 1{ }^{\circ} \mathrm{C}$; UR: $70 \pm 10 \%$; Fotofase: $14 \mathrm{~h} . \ldots \ldots \ldots$

0 Duração média dos instares larvais de Tuta absoluta criada em 8 dietas artificiais e em dieta natural. Temperatura: $25 \pm 1^{\circ} \mathrm{C}$; UR: $70 \pm 10 \%$; Fotofase: $14 \mathrm{~h}$. 
11 Duração média dos períodos larval e pupal e peso de pupas de Tuta absoluta mantida em dieta artificial com diferentes números de lagartas por tubo de criação. Temperatura: $25 \pm 1^{\circ} \mathrm{C}$; UR:

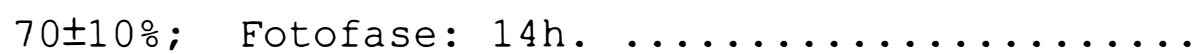

12 Duração e viabilidade do período embrionário de Tuta absoluta em diferentes temperaturas. UR: $60 \pm 10 \%$; Fotofase: $14 \mathrm{~h}$.

13 Duração dos período larval e pupal e peso de pupas fêmeas de Tuta absoluta criadas em dieta artificial e em diferentes temperaturas. UR:

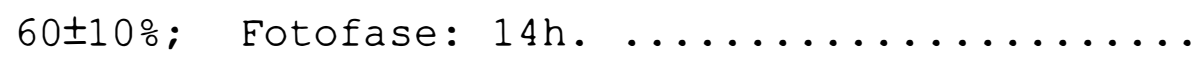

14 Duração dos períodos larval e pupal e peso de pupas que originaram machos de Tuta absoluta em dieta artificial e em diferentes temperaturas. UR: $60 \pm 10 \%$; Fotofase: $14 \mathrm{~h} . \ldots \ldots \ldots \ldots \ldots$

15 Número médio de ovos por fêmeas de Tuta absoluta criadas em dieta artificial e em diferentes temperaturas. UR: $60 \pm 10 \%$; Eotofase:

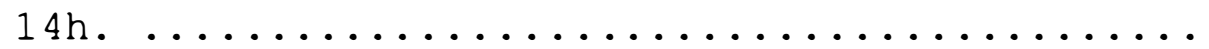

16 Longevidade média de machos e fêmeas de $T$. absoluta criados em dieta artificial e em

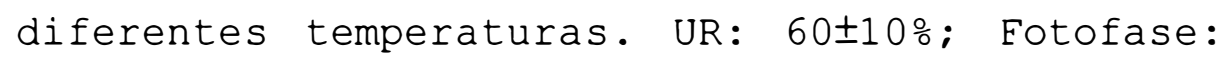

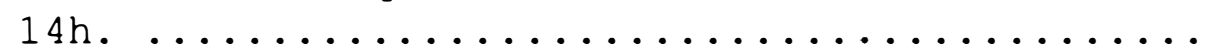

17 Temperatura base ( $\mathrm{Tb})$, constante térmica (K) e coeficiente de determinação $\left(R^{2}\right)$ de $T$. absoluta criada em dieta artificial e em diferentes temperaturas. UR: $60 \pm 10 \%$; Fotofase: $14 \mathrm{~h} . \ldots \ldots$

18 Número provável de gerações por ano de Tuta absoluta criada em dieta artificial, em regiões do Estado de São Paulo com isotermas

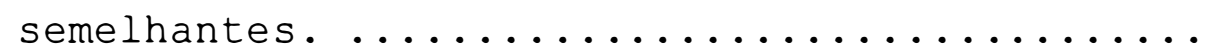

19 Parâmetros associados à tabela de vida de fertilidade de Tuta absoluta criada em 8 dietas artificiais e em dieta natural. Temperatura: $25 \pm 1{ }^{\circ} \mathrm{C}$; UR: $70 \pm 10 \%$; Fotofase: $14 \mathrm{~h} . \ldots \ldots \ldots$

20 Número médio de ovos por fêmea de Tuta absoluta criada em dieta artificial e em diferentes substratos de postura. T: 20,7士 $2,5^{\circ} \mathrm{C}$; UR: $70 \pm 10 \%$; Fotofase: $14 \mathrm{~h} . \ldots \ldots \ldots \ldots$ 
21 Longevidade média de machos de Tuta abspluta, obtidos de criação em dieta artificial e expostos a diferentes substratos de oviposição $\mathrm{T}: 20,7 \pm 2,5^{\circ} \mathrm{C}$; UR: $70 \pm 10 \%$; Eotofase: $14 \mathrm{~h} \ldots \ldots$ 


\section{BIOLOGIA E EXIGÊNCIAS TÉRMICAS DE}

\section{Tuta absoluta (Meyrick, 1917) EM DIETA ARTIFICIAL}

Autora: LAILA HERTA MIHSEELDT Orientador: Prof. Dr. JOSÉ ROBERTO POSTALI PARRA

\section{RESUMO}

A traça-do-tomateiro, Tuta absoluta (Meyrick, 1917) é uma das principais pragas do tomateiro, ocorrendo em diferentes regiões do Brasil. Entretanto, seu controle, muitas vezes, é dificultado, desde que os estudos sobre sua bioecolgia são problemáticos, pois ela é apenas criada em folhas de tomateiro. Assim, o presente trabalho teve por objetivo desenvolver uma dieta artificial para a criação do inseto sem a dependência do hospedeiro natural (tomateiro), bem como encontrar um local alternativo de oviposição, para estudar métodos racionais de controle da praga sem interrupções durante $O$ ano. Deste modo, a dieta mais adequada para a criação da traça-do-tomateiro foi o hospedeiro natural, no caso, folha de tomateiro 'Santa Clara' e, dentre as dietas artificiais, a que se mostrou mais promissora foi aquela composta de germe-de-trigo, farelo-de-soja, caseína, levedura-de-cerveja e feijão Branco, contendo pó de folhas de tomateiro. Este pó de folhas apresentou um efeito fagoestimulante, aumentando o "pegamento" inicial (menor mortalidade), bem como a 
viabilidade total do inseto no meio artificial. O número de ínstares foi constante e igual a 4 tanto nas dietas artificiais como na dieta natural, indicando a adequação nutricional dos meios artificiais. A temperatura mais adequada para a criação de T. absoluta esteve entre 18 e $25^{\circ} \mathrm{C}$ e, a partir da definição das exigências térmicas do inseto em dieta artificial com feijão Branco, constatou-se que podem ocorrer de 5,8 a 9 gerações de T. absoluta em localidades com isotermas entre 20 e $25^{\circ} \mathrm{C}$. A constante térmica para a fase de ovo-adulto, quando o inseto foi criado em dieta artificial, foi de 575GD. Os valores da tabela de vida de fertilidade, comparados através da estimativa de variância "jackknife", confirmaram que a dieta natural é a mais adequada para a criação de T. absoluta e, dentre as dietas artificiais a mais adequada foi aquela contendo feijão Branco acrescido de pó de folha de tomateiro e inadequada aquela contendo feijão 'Pintado'. O papel sulfite com atraentes visual (polietileno verde) e olfativo (extrato de folha) destacou-se como local alternativo de postura, podendo substituir as folhas de tomateiro normalmente empregadas em criações de laboratório. 


\section{BIOLOGY AND THERMAL REQUIREMENTS OF \\ Tuta absoluta (Meyrick,1917) \\ ON ARTIFICIAI DIET.}

Author: Laila Herta Mihsfeldt Adviser: Dr. José Roberto Postali Parra

\section{SUMMARY}

Tuta absoluta (Meyrick, 1917) is one of the most important pests on tomato on different regions of Brazil. However, its control is difficult because studies of it bioecology are very hard, due to fact of it is reared only on tomato leaves. So, this study had the purpose to develop an artificial diet for insect rearing without natural host plants, as well as to find an alternative oviposition surface, in order to study rational methods of pests control with no interruption along the year. By this way, most adequate diet for rearing $T$. absoluta were leaves of 'Santa Clara' tomato and, among artificial diets, the best was that one containing wheat germ, casein, yeast, soybean and white common bean plus tomato leaves powder. This last one showed an phagostimulant effect, low larval mortality and promoted higher total viabilities. The number of larval instars was constant and equal to 4 , as well on artificial diets as on tomato leaves (natural host), showing that the artificial diets are nutritionally suitable for rearing the insect. Most suitable temperature for rearing $T$. absoluta was between 18 and $25^{\circ} \mathrm{C}$ and 
considering the thermal requirements of the insect on artificial diet, the number of annual generations was estimated to be 5,8 to 9,0 on regions with temperatures between 20 and $25^{\circ} \mathrm{C}$. Thermal constant on egg - adult life cycle, when insect was reared on artificial diet, was 575 degree days. Parameters of fertility life table were compared using the "Jackknife method" estimates of variance and the most adequate diet for rearing the insects was the natural one (tomato leaves) and among artificial diets, best one was with white common bean plus tomato leaves powder and the worst one was with 'Pintado' common bean. Paper covered with visual (green polyethylene) and olfactory (liquid leaves extract) attractives was the most suitable oviposition surface and can replace tomato leaves normally used on laboratory rearing methods. 


\section{INTRODUÇÅO}

O tomateiro Lycopersicon esculentum Mill., está amplamente distribuido em todo o mundo e, no Brasil, é uma das hortaliças de maior interesse sócio-econômico, devido às grandes áreas cultivadas, seja para consumo in natura ou para 0 processamento industrial. 0 produto consumido in natura geralmente é obtido de cultivares do tipo estaqueado, enquanto que aquele destinado às indústrias é proveniente de cultivares rasteiras. Nas duas condições, as plantas são atacadas por um grande número de pragas e doenças, obrigando o tomaticultor a empregar tratamentos fitossanitários para controle. A utilização excessiva e constante do controle químico, associado às mudanças de cultivares de tomate utilizadas pelo agricultor, ao aumento de áreas de plantio e à expansão da cultura para novas localidades com condições climáticas diferentes, favoreceram $\bigcirc$ aparecimento de novas pragas (Gravena, 1984).

$\mathrm{Na}$ América do Sul, alguns insetos que eram considerados secundários, vêm se tornando pragas chaves dessa solanácea, provocando danos nas folhas e nos frutos e, especialmente importantes, por se manterem presentes durante todo o ciclo de desenvolvimento da cultura. Dentre estas pragas, a traça-do-tomateiro Tuta absoluta (Meyrick, 
1917) (Lepidoptera , Gelechiidae) merece ser destacada. Este inseto ataca intensamente as gemas e brotos terminais, construindo, nas folhas, galerias transparentes, devido ao consumo completo do mesófilo e, broqueando os frutos, chega a inutilizá-los completamente para a comercialização (Haji, 1984).

A traça-do-tomateiro, originalmente descrita como Phthorimaea absoluta (Meyrick, 1917), a partir de um único macho coletado em Huancayo, Peru, foi, por duas vezes, transferida de gênero: Clarke em 1965 transferiu-a para Gnorimoschema Busck,1900 e, em 1967, Povolny transferiu-a para Scrobipalpula Povolny, 1964 reconhecendo, porém, que a transferência era provisória (Povolny, 1975) . Após a revisão dos Gnorimoschenini, foi criado o gênero Scrobipalpuloides Povolny, 1987 no qual a espécie foi inserida (Povolny,1987). Segundo Estay (1996), em 1993, Povolny relatou que o gênero scrobipalpuloides é sinônimo de Tuta strand, 1910 e, portanto , o nome válido para a traça-do-tomateiro passou a ser Tuta absoluta (Meyrick, 1917 ) .

Devido à importância da traça-do-tomateiro, este trabalho tem por objetivo desenvolver uma dieta artificial que permita a criação do inseto sem a dependência da planta hospedeira, bem como estudar técnicas de obtenção de ovos em laboratório, sem o hospedeiro natural (tomateiro). A determinação de suas exigências térmicas, a partir da dieta desenvolvida na presente pesquisa, objetivará definir regiões nas quais o inseto será mais importante, por apresentar maior número de gerações. O estabelecimento de um sistema de criação, que 
permita a manutenção de grandes populações continuamente, é fundamental, desde que estudos de alternativas de controle deste inseto, tais como medidas comportamentais (feromônios sexuais), biológicas, culturais e mesmo químicas, utilizando-se produtos das novas gerações de inseticidas, poderão ser facilitados. 


\section{REVISÃO DE IITERATURA}

\subsection{Distribuição geográfica e hospedeiros}

A traça do tomateiro, Tuta absoluta (Meyrick, 1917), é um microlepidóptero minadơr, da família Gelechiidae. É um inseto da região neotropical, ocorrendo na Argentina (Bahamondes \& Mallea, 1969), Bolívia, Chile, Colômbia, Equador, Peru e Venezuela (Povolny, 1975), Uruguai (Carballo et al., 1981) e Brasil (Moreira et al., 1981 ).

No Brasil, a primeira citação do inseto foi feita em Jaboticabal, Estado de São Paulo (Moreira et al., 1981). Posteriormente, foi relatada nos estados do Paraná (Muszinski et al.,1982), Espírito Santo (Scardini et al., 1983), Rio de Janeiro (Gonçalves et al., 1983) e Bahia (Moraes \& Normanha Filho, 1982).

Segundo Vargas (1970), os hospedeiros da traça-do-tomateiro, são as plantas da família solanaceae, como o tomate (Lycopersicon esculentum Mill.), batata (Solanum tuberosum L.), fumo (Nicotiana tabacum L.), Solanum saponaceum Welw., Solanum guitoense Lam. (Povolny, 1975), além de maria-pretinha (Solanum nigrum L.), 
Lycopersicon puberulum Ph. e estramônio (Datura stramonium I. ) .

\subsection{Sintomas de ataque e prejuizos}

O ataque de T. absoluta em canteiros de mudas de tomate, segundo Bahamondes \& Mallea (1969) resultou em perda total, quando não havia tratamentos com inseticidas; o ataque a frutos, acarreta sua desvalorização comercial. No início do ataque, o dano pode passar despercebido devido ao pequeno tamanho do orifício de entrada da lagarta, mas quando o desenvolvimento larval é completado, observa-se uma auréola de cor amarelo-escura ao redor da perfuração por onde o adulto vai abandonar o hospedeiro. Este processo ocorre quando os frutos estão verdes e, pelo orifício aberto entram microrganismos que provocarão a sua total decomposição, principalmente se estiverem próximos da colheita.

Nas folhas atacadas pela traça-dotomateiro, observa-se, inicialmente, uma pequena mancha, semelhante a pequenas minas, que vai aumentando até ocupar grande parte do folíolo. Em ataques intensos, todo o tecido parenquimatoso da folha pode desaparecer sobrando apenas restos de nervuras de ambas as epidermes e acúmulos de excrementos, especialmente nos orifícios de entrada e saída das galerias. As lagartas podem se alimentar das partes tenras do caule, destruindo seu interior. O dano pode ocorrer também durante o florescimento, pois ao atacarem as flores impedem a fecundação. Os danos mais visíveis, 
entretanto, são feitos nos frutos em desenvolvimento e naqueles que estão amadurecendo. A traça entra por debaixo das sépalas, construindo galerias que se enchem de excrementos que poderão facilitar a podridão dos frutos (Vargas, 1970).

Assim, os danos causados pelas lagartas de T. absoluta podem ser observados nas folhas, caules e frutos. As lagartas quando éclodem entram nestas estruturas, constroem galerlas que aumentam à medida que o inseto se alimenta e cresce (Groppo, 1983). Segundo este autor, as folhas minadas amarelecem, murcham e caem, podendo ocorrer a morte da planta, $e$, quando o ataque é intenso, restam somente as nervuras das folhas. No talo e nos ponteiros, as lagartas se alimentam das partes tenras, broqueando-as. O fruto pode ser totalmente destruido, caindo em seguida.

Conforme já referido, esta praga encontra-se bastante disseminada por vários estados brasileiros. Assim, Scardini et al. (1983) observaram danos severos da praga em cultura de tomate no município de Santa Teresa - ES, com perdas de até 100\% na produção.

Em experimentos conduzidos em condições de campo, Nakano \& Paulo (1983) constataram, em São Paulo, que os prejuízos provocados pela traça podem chegar a $88,9 \%$. 


\subsection{Aspectos biológicos}

Por não existir ainda uma dieta artificial adequada para a criação do inseto, a maioria dos dados biológicos registrados na literatura, foram obtidos em dieta natural. Assim, em condições de campo, Herrera (1963) observou que T. absoluta apresenta um período de pré-oviposição de dois dias, registrando que a cópula durou 15 minutos. O período de oviposição da traça foi de 8,8 dias, com uma média de 112,8 ovos por fêmea; à longevidade das fêmeas foi maior $(29,6$ dias $)$ que a dos machos $(16,7$ dias)

Em condições de laboratório, sob diferentes temperaturas, Vargas (1970) estabeleceu que o período de incubação desta espécie foi de 6,7 dias à $20,05^{\circ} \mathrm{C}$ e 4,3 dias à $24,7^{\circ} \mathrm{C}$. O período larval durou 26,1 dias à $17,9^{\circ} \mathrm{C}$ e 14,5 dias à $25,1^{\circ} \mathrm{C}$ e o período pupal 14,68 dias à $18,37^{\circ} \mathrm{C}$, 8,6 dias à $24,52^{\circ} \mathrm{C}$ e 8 dias à $25,46^{\circ} \mathrm{C}$. A longevidade das fêmeas e machos acasalados foi, respectivamente, de 10,4 e 6,6 dias, sendo os insetos virgens mais longevos.

Razuri \& Vargas (1975) trabalhando em condições de laboratório à temperatura de $24 \pm 1^{\circ} \mathrm{C}$, por três gerações consecutivas, observaram redução gradativa tanto para as durações dos períodos larval e oviposição como para a longevidade de machos e fêmeas acasalados com o passar das gerações. Entretanto, ao longo das gerações estudadas, - mesmo não aconteceu em relação às durações do período 
pré-pupal, pupal, de pré-oviposição e longevidade de adultos não acasalados. A maior fecundidade ocorreu na $2^{\text {a }}$ geração, com o mesmo período de incubação para as três gerações estudadas.

Pesquisando a traça, em condições de laboratório, à temperatura de $14,5^{\circ} \mathrm{C}$, Quiroz (1976) obteve valores médios de 6,27 e 16 dias para os períodos de incubação, larval e pupal, respectivamente. Segundo este autor, a capacidade de postura de uma fêmea é cerca de 40 ovos.

A partir de pupas coletadas no campo, Muszinski et al. (1982) relataram que após 13 dias emergiram os adultos de T. absoluta. Em gaiolas, os autores observaram que a oviposição ocorreu em ambas as faces das folhas do tomateiro e que os ovos permaneciam presos aos pêlos foliares. Cada fêmea colocou uma média de 40 ovos, com um período de incubação de 5 dias. Segundo os autores, inicialmente as larvas perfuram a epiderme para se alimentar, durante seis dias, no tecido parenquimatoso, destruindo até as nervuras. Descem, então, para o caule abrindo galerias para alimentarem-se por mais sete dias para depois puparem nas folhas.

Uma média de 200 ovos por fêmea com viabilidade de 95\% foi relatada por Souza et al. (1983). Segundo os autores, a longevidade média dos adultos é de 22 dias; o período de incubação é variável de 4 a 7 dias, enquanto que as fases larval e pupal duram 14 e 8 dias, respectivamente. 
Em condições de laboratório, Erança et al. (1984) obtiveram um ciclo biológico da traça de 50 dias, sendo os períodos de incubação, larval e pupal, respectivamente, de 4,$5 ; 13,0$ e 10,1 dias.

Salas \& Fernandez (1985) obtiveram uma duração média de 4,5 dias para o período de incubação; para as fases larval e pupal, respectivamente, 12,0 e 7,0 dias, com longevidade de adultos de 31,0 dias, sem levar em consideração se eram machos ou fêmeas.

Paulo (1986) estudando a biologia de $T$. absoluta em condições de laboratório à temperatura de $26^{\circ} \mathrm{C}$, verificou que a duração média do ciclo biológico foi de 49,2 dias. Cada fêmea colocou 105 ovos com 99\% de viabilidade e um período de incubação médio de 5,6 dias. Estes ovos foram colocados, na grande maioria, nos três primeiros dias de postura. As durações das fases larval e pupal foram de 13,6 e 8,8 dias, respectivamente. A longevidade média dos machos foi menor $(19,6$ dias) que a das fêmeas $(22,9$ dias).

Em condições de laboratório, à temperatura de $22,8^{\circ} \mathrm{C}$, Coelho \& França (1987) obtiveram um período médio de incubação de 4,8 dias, com a viabilidade variando entre 78,7 e $95,0 \%$, ocorrendo alta mortalidade após a eclosão. Os autores relataram, ainda, que a duração do período larval foi de 13 dias e que a fase pupal foi completada após 10 a 11 dias, com viabilidade de $80 \%$ e relação sexual de 1 macho para 1,8 fêmeas.

$$
\text { Haji et al. (1988) obtiveram }
$$

viabilidade das fases de ovo, larval e pupal de 44,46; 
20,97 e 68,19\%, respectivamente, quando a traça-dotomateiro foi criada à temperatura de $27^{\circ} \mathrm{C}$. As durações dos período de incubação, larval e pupal foram, respectivamente, de 4,30; 10,95 e 6,15 dias. O número de ovos por fêmea foi de 55,16. A longevidade dos machos foi de 9,69 dias e das fêmeas 11,52 dias, sendo o ciclo total completado em 38,12 dias.

Criando a traça em laboratório com temperatura média de $18,55^{\circ} \mathrm{C}$, umidade relativa de $65,48 \% \mathrm{e}$ fotofase de 12 horas, Imenes et al.(1990) estudaram o comportamento reprodutivo de casais alimentados com solução de mel a $10 \%$ com aqueles que receberam apenas água e observaram que o número de acasalamentos, período de préoviposição, número de posturas/fêmea, total de ovos/fêmea, longevidade de machos e fêmeas e viabilidade dos ovos foi maior para adultos alimentados com solução de mel. Os autores constataram, ainda, a viabilidade da criação sem a necessidade de alimentarem os adultos.

Giustolin et al.(1995) testaram dez dietas artificiais contendo diferentes fontes protéicas e observaram que aquelas que propiciaram alta viabilidade larval causaram maior porcentagem de adultos deformados, enquanto que aquelas com baixa porcentagem de deformação nos adultos apresentaram baixas viabilidades larvais. Todas as dietas, entretanto, produziram insetos que tiveram alta viabilidade pupal. Segundo os autores, embora nenhuma das dietas tenha proporcionado um desenvolvimento comparável àquele obtido nas folhas de tomateiro (testemunha), foi possível selecionar uma dieta como a mais adequada para a 
traça, tendo como fontes protéicas feijão "Carioca", germe de trigo, caseína, levedura de cerveja e proteína de soja.

Visando a manutenção de uma população estoque da traça do tomateiro em laboratório para estudos com parasitóides de ovos, Pratissoli (1995) desenvolveu uma metodologia de criação, empregando folhas de tomateiro para o desenvolvimento larval e como substrato de oviposição.

Para empregar feromônios sexuais no controle da traça são necessários vários estudos básicos de comportamento do inseto e para tal Uchoa-Fernandes et al. (1995) estudaram o acasalamento e a oviposição de $T$. absoluta em casa-de-vegetação telada, observando que sob fotoperiodo natural os adultos apresentaram atividade de vôo no início da manhã, com acasalamentos entre 6:00 e 7:00 h. As fêmeas só acasalaram uma vez por dia, com o período de cópula durando, em média, $4 \mathrm{~h}$ e $45 \mathrm{~min}$. A oviposição acontece das 6:00 às 18:00h, com pico entre 15:00 e 18:00h. Em condições de campo, as larvas puparam no solo em tomate rasteiro e nas folhas, quando o tomate era do tipo estaqueado.

Estudando a biologia de T. absoluta em folhas de tomateiro, em temperaturas constantes e flutuantes, Bentacourt et al. (1996) determinaram que a constante térmica para a fase de ovo foi de 72,2 GD; para as fases de lagarta e pupa foram necessários 267,1 e 130,7 GD, respectivamente, para que os períodos fossem completados. Os mesmos autores determinaram, também, os limiares de desenvolvimento como sendo de $9,7{ }^{\circ} \mathrm{C}$ para a fase de ovo e para as fases de lagarta e pupa estes valores foram de 6,0 e $9,1^{\circ} \mathrm{C}$, respectivamente. 
Ferreira \& Anjos (1997) concluiram que a traça do tomateiro apresenta 4 instares larvais quando criada à temperatura constante de $25^{\circ} \mathrm{C}$ e fotofase de 12 horas. As lagartas de $1^{\circ}$ ínstar são de coloração verdeclara, com cabeça mais larga que o corpo e de cor marrom; as do $2^{\circ}$ e $3^{\circ}$ instares apresentam coloração verde cada vez mais intensa, à medida que vão se alimentando das folhas de tomateiro e, no $4^{\circ}$ e último ínstar, as lagartas apresentam coloração verde escura, com uma faixa longitudinal dorsal rósea que se torna avermelhada e bem distinta quando as lagartas estão próximas à pupação.

A biologia da traça foi estudada, em tomateiro cultivar IPA 5, por Pires \& Marques (1997) para aprimorar sua metodologia de criação através do armazenamento de ovos e pupas em geladeira e, tal fato permitiu o retardamento do desenvolvimento do inseto em até 15 dias sem, no entanto, ocorrer diminuição da viabilidade larval e no número de adultos correspondentes.

Úlle (1996) buscou a determinação do momento crítico de controle da traça do tomateiro e para tal avaliou o desenvolvimento larval, pupal e de oviposição deste inseto em laboratório, casa-de-vegetação e campo. Segundo o autor, as plantas de tomateiro apresentam maior concentração de ovos em seu terço superior e, portanto, as amostragens devem ser direcionadas para esta parte da planta, pois a desuniformidade no comprimento das minas produzidas nos $3^{\circ}$ e $4^{\circ}$ instares larvais transforma este parâmetro de avaliação em um indicador inadequado para o monitoramento e controle da praga. 
Giustolin et al. (1997) determinaram o número de instares larvais de $T$. absoluta alimentadas com folhas das cultivares Santa Clara e PI 134417 em duas temperaturas, concluindo que o inseto apresenta 4 instares larvais e que este número não foi afetado nem pelas temperaturas $\left(20\right.$ e $\left.30^{\circ} \mathrm{C}\right)$, nem pelos genótipos. Empregando as mesmas cultivares de tomateiro, Vendramin et al. (1997) compararam a biologia do inseto criado em condições de laboratório e de casa-de-vegetação visando estudos com entomopatógenos e estabeleceram que o emprego de placas plásticas, em condições de laboratório, é a técnica mais adequada e prática para os estudos das interações inseto, planta hospedeira e entomopatógenos. O efeito negativo da linhagem PI 134417, sobre a biologia da traça do tomateiro pôde ser notado tanto nos ensaios de laboratório como nos da casa-de-vegetação . 


\section{MATERIAL E MÉTODOS}

Os experimentos referentes à biologia comparada e em diferentes temperaturas de Tuta absoluta (Meyrick,1917) foram conduzidos no laboratório de Biologia de Insetos do Departamento de Entomologia da Escola Superior de Agricultura "Luiz de Queiroz" (ESALQ) Universidade de São Paulo (USP), em Piracicaba, São Paulo, à temperatura de $25 \pm 1^{\circ} \mathrm{C}$, umidade relativa de $70 \pm 10 \%$ e fotofase de 14 horas.

O experimento para obtenção de um substrato alternativo de postura foi instalado no laboratório de Entomologia da Fundação Faculdade de Agronomia "Luiz Meneghel" (FFALM), em Bandeirantes, Paraná, no período de abril a julho de 1997, à temperatura média de $20,7 \pm 2,5^{\circ} \mathrm{C}$, umidade relativa de $60 \pm 10 \%$ e fotofase de 14 horas.

\subsection{Biologia comparada de T. absoluta em dietas artificiais}

O desenvolvimento larval e pupal de $T$. absoluta foi estudado em 8 dietas artificiais, comparando-o com aquele em dieta natural (folhas de tomateiro 'Santa Clara'). Tomou-se como base a dieta de Greene et al. (1976) 
(Tabela 1) que se mostrara promissora em trabalhos anteriores desenvolvidos por Giustolin et al. (1995). A variável da dieta foi uma das fontes protéicas, ou seja, o feijão cozido. Baseando-se em pesquisas anteriores de Parra \& Carvalho (1984) de que variedades de tegumento escuro, por terem mais tanino, propiciam uma menor digestibilidade e, portanto, pior desenvolvimento para spodoptera frugiperda (J.E. Smith, 1797), optou-se por variedades de tegumento claro. Como neste trabalho, os autores selecionaram a variedade 'Carioca' como a mais adequada, a dieta que a continha foi incluída na comparação (testemunha).

Tabela 1: Composição da dieta modificada de Greene et al. (1976) :

\section{Componente}

\section{Quantidade}

Feijão (*)

Germe de trigo

Farelo de soja

Caseína

Levedura de cerveja

Ácido ascórbico

Ácido sórbico

Nipagin (metilparahidroxibenzoato)

Tetraciclina

Formaldeído

Solução vitamínica $(* *)$

Ágar

Agua

(*) variável da dieta
$75,0 \mathrm{~g}$

$60,0 \mathrm{~g}$

$30,0 \mathrm{~g}$

$30,0 \mathrm{~g}$

$37,5 \mathrm{~g}$

$3,6 \mathrm{~g}$

$1,8 \mathrm{~g}$

$3,0 \mathrm{~g}$

$113,0 \mathrm{mg}$

$3,6 \mathrm{ml}$

$9,0 \mathrm{ml}$

$23,0 \mathrm{~g}$

$1200,0 \mathrm{ml}$

\footnotetext{
composição da mistura vitamínica (Parra, 1996): niacinamida: 1,0g; pantotenato de cálcio: 1,0g; tiamina: 0,5g; piridoxina: 0,25g; ácido fólico: 0,1g; biotina: 0,02g; vitamina $B_{12}(1000 \mathrm{mg} / \mathrm{cc}): 2,0$ $\mathrm{ml}$. Estes componentes são diluídos em $1000 \mathrm{ml}$ de água destilada e agitados para que haja uma perfeita homogeneização.
} agitados para que haja uma perfeita homogeneização. 
Foram estudadas, além da dieta com feijão 'Carioca', dietas com as cultivares Jalo, Aeté-6, EmgopaOuro e Pintado e o feijão conhecido comercialmente como Branco. Foram acrescentadas para comparação do desenvolvimento biológico de T. absoluta, ao lado das 6 dietas, 2 outras, ambas contendo feijão branco; uma delas com extrato de folhas e outra com pó de folhas de tomateiro variedade 'Santa Clara', objetivando aumentar a ação fagoestimulante da dieta.

Para obtenção do extrato de folhas, pesaramse $15 \mathrm{~g}$ de folhas e estas foram trituradas em meio aquoso, em liqüidificador. Os resíduos foram eliminados coando-se o material proveniente do liqüidificador; o volume final foi medido para ser descontado do volume de água normalmente utilizado no preparo da dieta. Assim, no final do processo de preparo da dieta acrescentou-se o extrato juntamente com os anticontaminantes. Para obtenção do pó de folhas, estas foram secas em estufa e moídas. Este pó foi acrescentado na concentração de 5\% (15g) na dieta. Como testemunha, foram utilizadas folhas de tomateiro, variedade 'Santa Clara'.

As dietas foram preparadas de acordo com a metodologia descrita por Parra (1996), tomando-se apenas o cuidado de se reduzir o tamanho das partículas dos ingredientes empregados na elaboração da dieta, através de moagem prévia, devido ao pequeno tamanho das lagartas.

Os meios, depois de preparados, foram transferidos para tubos de vidro $(8,5 \mathrm{~cm}$ de altura $\times 2,3 \mathrm{~cm}$ de diâmetrol, previamente tamponados com algodão hidrófugo 
e esterilizados a seco em estufa a $100^{\circ} \mathrm{C}$, pelo tempo de 2 horas.

Cada tubo recebeu uma quantidade suficiente de dieta para que o período larval fosse completado e não houvesse o ressecamento do meio. Após 24 horas, foram colocadas em câmara asséptica por um período de 60 minutos, para esterilização externa. Nesta mesma câmara também foi feita a "inoculação" das lagartas recém - eclodidas.

Tais lagartas foram obtidas de ovos colocados por fêmeas criadas em folhas de tomateiro. Os ovos depositados nas folhas foram retirados com o auxílio de um pincel de pêlo natural e acondicionados em placas de Petri, forradas com papel de filtro levemente umedecido e vedadas com filme de PVC transparente, para que o período de incubação fosse completado. Assim, as lagartas recémeclodidas foram transferidas para o interior do tubo contendo dieta, com o auxílio de um pincel de pêlo natural, colocando-se três lagartas por tubo. Em cada dieta avaliaram-se 100 tubos.

Após a "inoculação" das lagartas, os tubos foram acondicionados em estantes de madeira para que o desenvolvimento larval fosse completado. Os tubos foram revisados diariamente para se observar a data de pupação (Figura 1). As pupas ficavam no algodão (Figura 2) e eram retiradas com o auxílio de pinças e transferidas, individualmente, para tubos de vidro $(4,0 \mathrm{~cm}$ de altura $x$ 0,5 cm de diâmetrol, tamponados com algodão hidrófilo e devidamente identificados. 

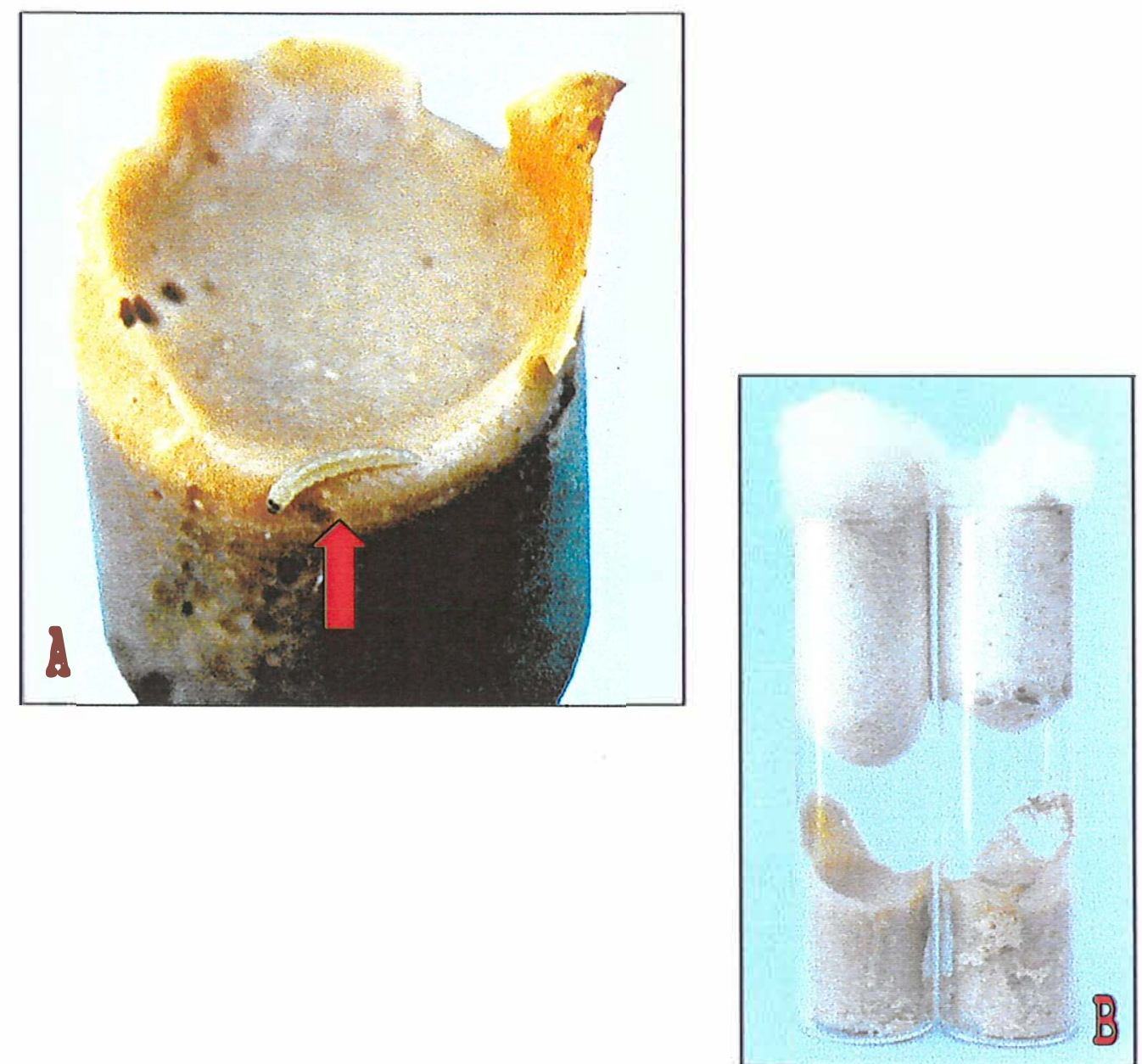

Figura 1. Técnica de criação de T. absoluta em dieta artificial. A - Lagarta de T. absoluta em dieta artificial; B - Aspecto da dieta artificial utilizada para a criação de T. absoluta em tubo de vidro. 


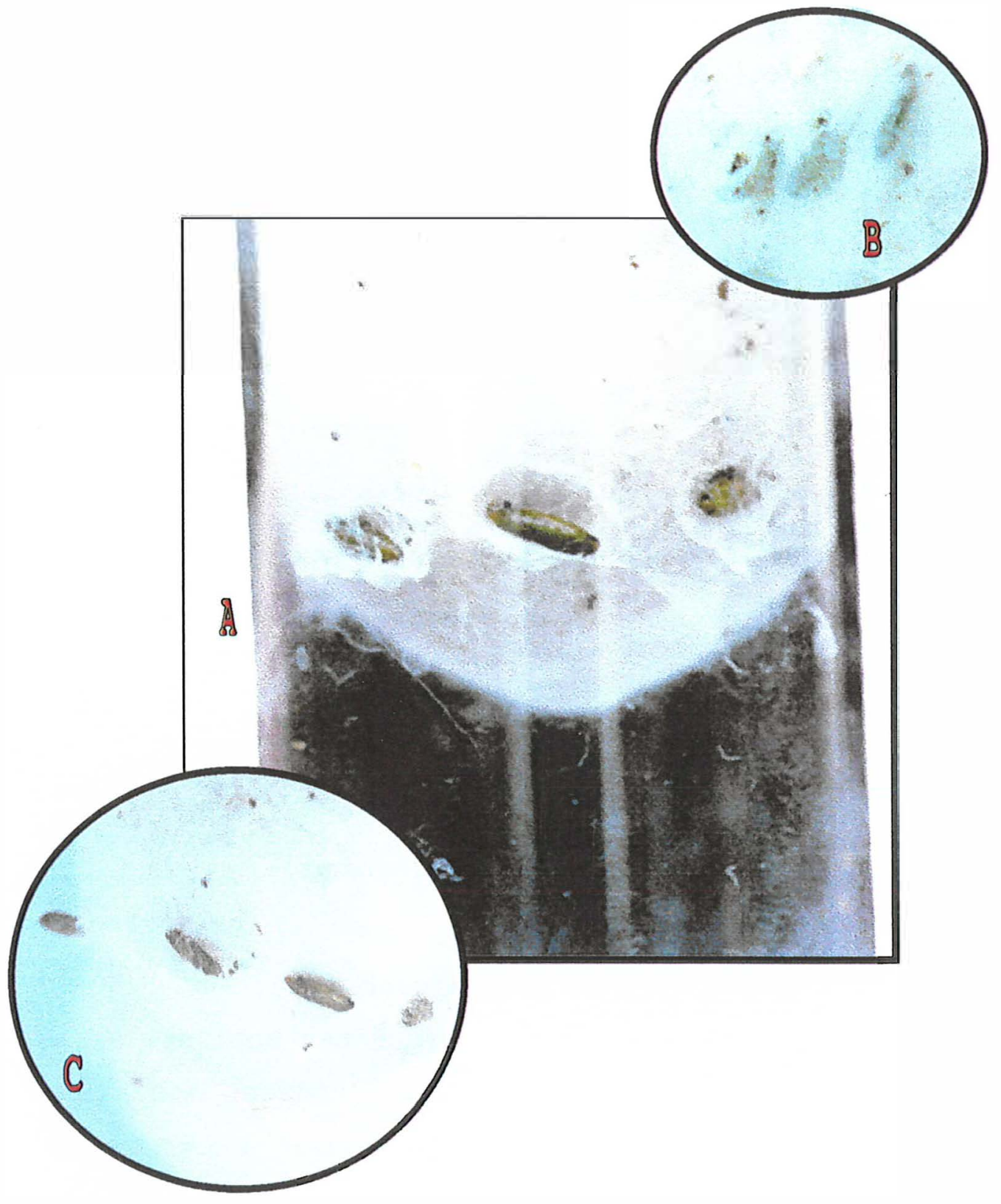

Figura 2. Pupas de T. absoluta sobre algodão em tubos de dieta artificial (A). Detalhes das pupas dentro (B) e sobre o algodão (C). 
Após 24 horas, as pupas foram pesadas em balança analítica e separadas por sexo (Butt \& Cantu, 1962; Quiroz, 1976). A emergência foi observada para determinação da duração do período pupal e se os adultos emergidos eram normais ou se apresentavam algum tipo de deformação.

Os seguintes parâmetros biológicos foram avaliados em cada uma das dietas testadas:

- duração e viabilidade da fase larval;

- número de ínstares;

- duração e viabilidade da fase pupal;

- peso de pupas (machos e fêmeàs)

- porcentagem de pupas deformadas;

- razão sexual = número de fêmeas/ (número de fêmeas + número de machos)

- porcentagem de adultos deformados;

- porcentagem de contaminação por fungos e/ou bactérias.

Para determinação do número de ínstares dos insetos mantidos nas 8 dietas, foram separados 60 tubos por dieta, com apenas uma lagarta inoculada, medindo-se diariamente a largura de sua cápsula cefálica. Como testemunha, mediu-se a largura da cápsula cefálica de 60 lagartas alimentadas com folíolos de tomate, variedade 'Santa Clara'. Estas medições foram feitas com um medidor WILD MMS 235, acoplado a um microscópio estereoscópico.

Para a observação dos adultos, foram formados casais a partir de adultos recém-emergidos. Cada casal foi mantido em uma "gaiola" que consistia de um tubo 
de vidro $(8,0 \mathrm{~cm}$ de altura $\times 2,5 \mathrm{~cm}$ de diâmetro) colocado com a abertura sobre uma placa de isopor, previamente perfurada, em círculo, com vasador. No centro deste círculo foi feita outra perfuração para sustentar um outro tubo de vidro $(4,0 \mathrm{~cm}$ de altura $\times 0,3 \mathrm{~cm}$ de diâmetro), contendo água para manter a turgescência do folíolo de tomateiro que serviu de substrato de postura. Ao lado deste pequeno vidro foi colocado um pequeno pedaço de rolo dental umedecido com solução de mel a 10\% para fornecer alimento aos adultos (Eigura 3). Diariamente, contavam-se os ovos e procedia-se à troca do folíolo de tomateiro.

Os seguintes parâmetros biológicos foram avaliados em cada dieta nesta fase adulta:

- total de ovos por fêmea;

- longevidade de machos e fêmeas.

Para o estudo da biologia em folhas de tomateiro, foi colocado, em vidros de $8,0 \mathrm{~cm}$ de altura $x$ 2,5 cm de diâmetro, um folíolo de tomateiro com um chumaço de algodão hidrófilo umedecido envolvendo a sua extremidade inferior para evitar o seu ressecamento. Em cada tubo foram "inoculadas" três lagartas, avaliando-se os mesmos parâmetros biológicos observados nas dietas artificiais.

O delineamento experimental empregado foi inteiramente casualizado, sendo os resultados submetidos à análise de variância e as médias comparadas, através do teste de Tukey, no nível de 5\% de probabilidade. 


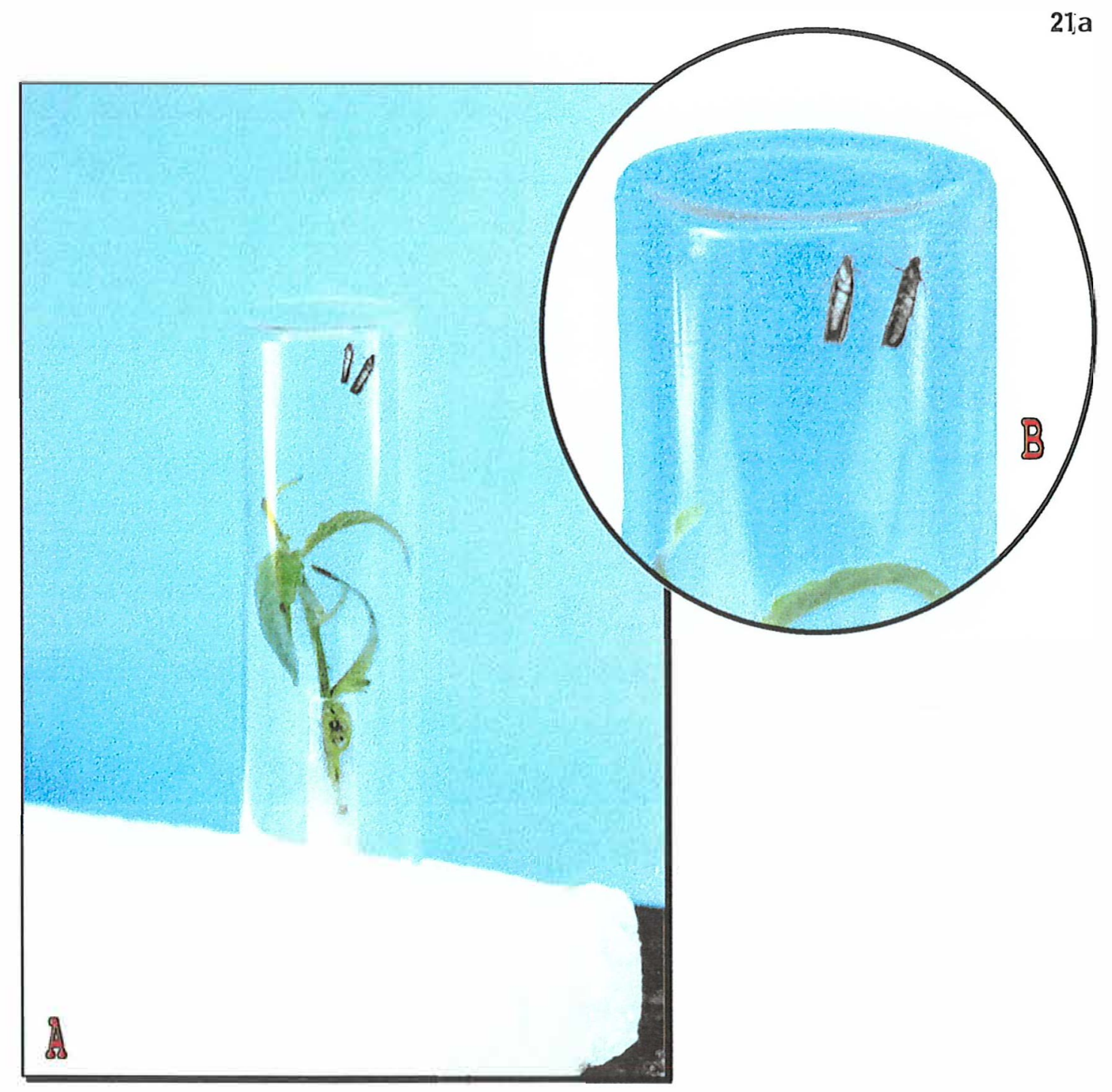

Eigura 3. Tubo de vidro para avaliar a capacidade de postura de T. absoluta. A - Tubo de vidro contendo internamente recipiente menor com água e algodão e folíolo de tomateiro; B - Casal de T. absoluta no interior do tubo de vidro. 
3.2 Determinação do número ideal de lagartas de $T$. absoluta por tubo de criação

A partir dos resultados do item 3.1, definiu-se a variedade de feijão mais adequada e facilmente encontrada no mercado para ser empregada na confecção da dieta para T. absoluta e foi instalado um experimento para se determinar o número ideal de lagartas a ser "inoculado" por tubo de criação. Assim, "inocularam-se" duas, quatro, oito, doze, dezesseis e vinte lagartas por tubo. Avaliaramse as durações e viabilidades dos períodos larval e pupal, o peso das pupas com 24 horas de idade e a porcentagem de deformação de adultos nos diferentes tratamentos.

O delineamento experimental empregado foi inteiramente casualizado, sendo os resultados submetidos à análise de variância e as médias comparadas através do teste de Tukey, no nível de 5\% de probabilidade.

\subsection{Biologia da traça-do-tomateiro em diferentes temperaturas}

A biologia de T. absoluta foi estudada em 7 temperaturas na dieta mais adequada (item 3.1) visando a determinação das exigências térmicas da traça-do-tomateiro. Foram colocados 100 tubos de dieta por temperatura e em cada um deles foram "inoculadas" três lagartas recém eclodidas provenientes de ovos de fêmeas criadas por três gerações na dieta artificial, tempo suficiente para que o inseto pudesse recuperar a sua variabilidade genética, 
perdida devido à "deriva genética", seleção e "inbreeding" (cruzamento entre irmãos) (Parra, 1996).

Utilizaram-se temperaturas de 18, 20, 22, 25, 28,30 e $32^{\circ} \mathrm{C}$, mantidas em câmaras climatizadas, com fotofase de 14 horas e umidade relativa de $60 \pm 10 \%$.

Os seguintes parâmetros biológicos foram avaliados em cada uma das temperaturas:

- duração da fase de ovo;

- duração e viabilidade do período larval;

- peso das pupas com 24 horas de idade;

- duração e viabilidade do período pupal;

- número médio de ovos por fêmea;

- longevidade de machos e fêmeas;

- porcentagem de adultos deformados.

A avaliação destes parâmetros biológicos foi realizada conforme 3.1 .

Para a determinação do período de incubação, foram retirados ovos de T. absoluta das folhas de tomateiro, com auxílio de um pincel de pêlo natural e estes foram transferidos em número de 25, para placas de Petri forradas com papel de filtro, levemente umedecido com água destilada e vedadas com filme de PVC. Em cada temperatura estudada, foram feitas 6 repetições, perfazendo um total de 150 ovos. Diariamente, contava-se o número de lagartas eclodidas.

Em cada temperatura, acompanhou-se a longevidade de machos e fêmeas e o período de oviposição 
como descrito no ítem 3.1.; a sobrevivência de adultos foi estimada pela equação de Weibull (Sgrillo, 1982).

\subsection{Determinação das exigências térmicas e número anual de gerações de T. absoluta.}

As exigências térmicas de T. absoluta foram determinadas pelo método da hipérbole (Haddad \& Parra, 1984), baseando-se na duração do período ovo-adulto obtido nas temperaturas de $18,20,22,25,28,30$ e $32^{\circ} \mathrm{C}$.

Com tais dados, determinou-se o provável número de gerações da praga nas principais regiões produtoras de tomate do Estado de São Paulo, baseando-se nas normais climatológicas e no modelo proposto por Parra (1981) para Perileucoptera coffeella (Guérin - Méneville, 1842) em cafeeiro.

\subsection{Tabela de vida de fertilidade}

A partir dos resultados obtidos nas diferentes dietas (3.1.) e temperaturas (3.4), foram elaboradas tabelas de vida de fertilidade segundo Silveira Neto et al. (1976), calculando-se os seguintes índices:

- taxa líquida de reprodução ( Ro );

- razão finita de aumento $(\lambda)$;

- capacidade inata de aumentar em número ( $r m$ );

- duração do período de uma geração ( T );

- tempo de duplicação de gerações ( Td ). 
Os valores destes indices para as dietas foram comparados pelo teste $t$, para tal, a variância foi calculada pela técnica computacionalmente intensiva "jackknife" (programa SAS) (Meyer et al., 1986; Hulting et al., 1990; Luiz \& Maia'; Maia et al. ${ }^{2}$ ). A partir destes dados foram construídos gráficos, representando os valores médios de cada um dos parâmetros com seus respectivos intervalos de confiança.

\subsection{Local alternativo de postura de $\mathrm{T}$. absoluta.}

Devido à dificuldade na coleta de ovos de T. absoluta nas folhas de tomateiro, a técnica de criação do inseto em dieta artificial só estará completa se for encontrado um local onde a coleta seja facilitada, sem o hospedeiro natural (folhas de tomateiro), à semelhança de outros lepidópteros normalmente criados em laboratório.

Testaram-se diferentes substratos de postura e estes foram comparados a uma testemunha representada pela folha de tomateiro.

Os insetos foram criados na dieta artificial selecionada em 3.1.1 por três gerações. As pupas obtidas foram individualizadas e separadas por sexo em vidros de

${ }^{1}$ LUIZ, A.J.B. \& MAIA, A.H.N. Comparação de paråmetros associados a tabelas de vida e fertilidade utilizando jackknife: aspectos computacionais. Trabalho apresentado à Reuniåo Anual da Região Brasileira da Sociedade Internacional de Biometria, Araraquara, 1998 . tabelas de vida e fertilidade usando jackknife: estudo de impacto de biopesticidas em insetos não-alvo. Trabalho apresentado na Reunião Anual da Região Brasileira da Sociedade Internacional de Biometria, Araraquara, 1998. 
4,0 cm de altura $\times 0,5 \mathrm{~cm}$ de diâmetro. Após a emergência, formaram-se casais com individuos emergidos em um mesmo dia.

Os recipientes para o acasalamento e postura eram formados por copos plásticos transparentes de $11,5 \mathrm{~cm}$ de altura $\times 6,0 \mathrm{~cm}$ de diâmetro. Estes copos foram colocados, de boca para baixo, sobre uma placa de Petri forrada com papel de filtro. O fundo do copo foi perfurado com vasador e através deste orifício introduziam-se os adultos. Após a colocação destes adultos, a abertura era fechada com um pequeno chumaço de algodão hidrófilo que era, então, umedecido com solução de mel a $100^{\circ}$ para que os adultos pudessem se alimentar.

Os tratamentos testados foram:

a) copo plástico revestido internamente com papel sulfite umedecido com $1 \mathrm{ml}$ de extrato de folha de tomateiro.

Este extrato foi obtido pela imersão de $6 \mathrm{~g}$ de folhas de tomateiro em $60 \mathrm{ml}$ de éter etílico. Esperou-se a. completa evaporação do solvente para que as folhas pudessem ser lavadas com $50 \mathrm{ml}$ de água destilada. O líquido obtido foi coado e acrescentou-se 1 gota de espalhante para promover uma perfeita homogeneização do material extraído das folhas com a água destilada. Esta solução, quando não atilizada, foi guardada em geladeira (Eigura 4a).

b) copo plástico revestido internamente com papel sulfite com uma cobertura de polietileno verde. O papel sulfite foi, também, umedecido com $1 \mathrm{ml}$ de extrato de folhas (Eigura $4 \mathrm{~b}$ ). 


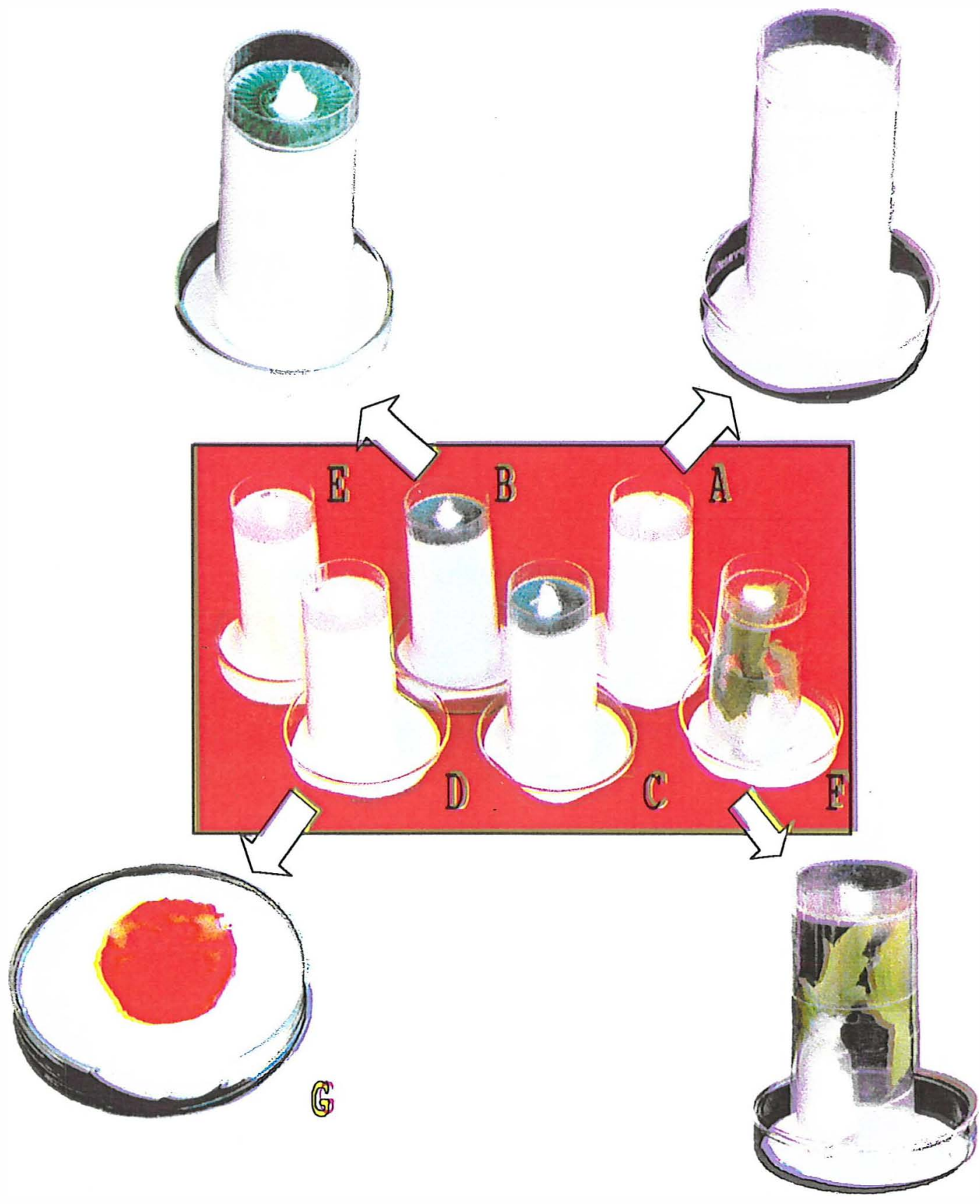

Eigura 4. Tratamentos estudados como local alternativo de postura de $T$. absoluta $(A-F)$. A-Copo plástico + papel sulfite + extrato de folha de tomateiro; B-Copo plástico + papel sulfite + polietileno verde + extrato de folha de tomateiro; C-Copo plástico + papel sulfite + polietileno verde + fatia do fruto do tomateiro; DCopo plástico + papel sulfite + fatia do fruto do tomateiro; E-Copo plástico + papel sulfite; F-Copo plástico + folíolo do tomateiro; G-Detalhe da fatia do fruto do tomateiro colocado sob o papel de filtro. 
c) copo plástico revestido internamente com papel sulfite e plástico verde. O copo foi colocado sobre uma placa de Petri forrada com papel de filtro e por baixo deste papel colocou-se uma fatia de tomate (Figura 4c).

d) copo plástico revestido internamente com papel sulfite e colocado sobre uma placa de Petri forrada com papel de filtro, sob o qual foi colocada uma fatia de tomate (Figura 4d).

e) copo plástico revestido internamente com papel sulfite (Figura 4 e)

f) copo plástico contendo em seu interior uma folha de tomateiro. A folha foi envolvida, em sua extremidade inferior, com algodão e colocado em vidro de $4,5 \mathrm{~cm}$ de altura $\times 1,5 \mathrm{~cm}$ de diâmetro, contendo água para manter a sua turgescência (Eigura $4 \mathrm{f}$ ).

Além da folha de tomateiro, substrato normalmente empregado para oviposição da traça, testaram-se prováveis estímulos olfativos extraídos das folhas do hospedeiro natural através do uso de um solvente bastante volátil (éter sulfúrico), estímulos visuais (polietileno verde) e odores obtidos do próprio fruto do tomateiro.

Diariamente, para se fazer a contagem dos ovos, retiravam-se os adultos com o auxílio de um aspirador bucal. Após esta coleta, preparava-se novamente o recipiente, retornando os adultos às gaiolas. Este procedimento foi feito até a morte de todos os adultos de cada repetição por tratamento. 
Tabela 2: Locais de postura testados para T. absoluta em laboratório.

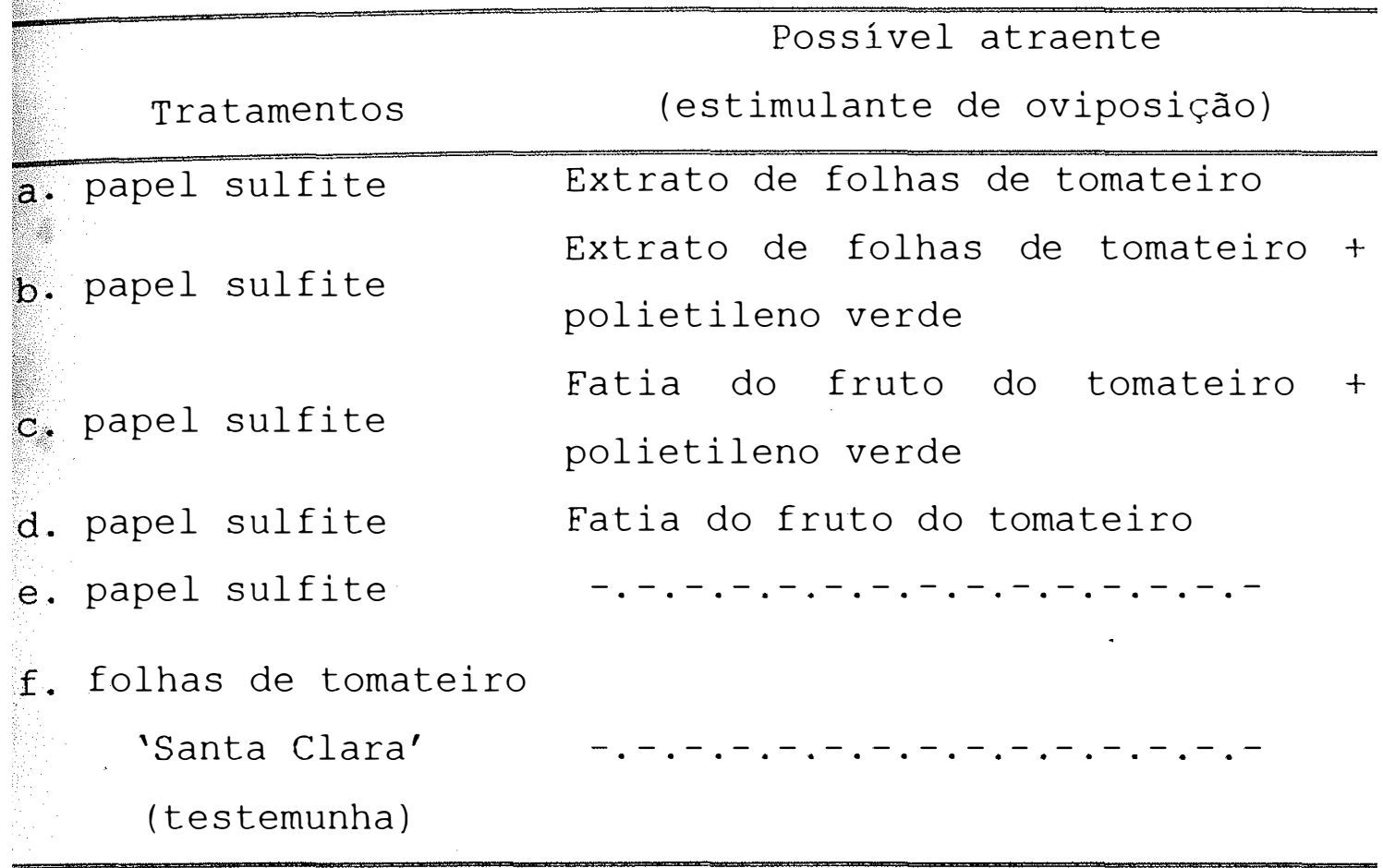

Em cada tratamento foram empregados um, dois ou três casais dependendo do número de adultos emergidos no dia. Eoram instaladas 11 repetições e a cada dia anotava-se a mortalidade por sexo.

O delineamento experimental empregado foi inteiramente casualizado, sendo os resultados submetidos à análise de variância e as médias comparadas através do teste de Tukey, no nível de 5\% de probabilidade. 


\section{RESULTADOS E DISCUSSÃO}

\subsection{Biologia comparada de Tuta absoluta (Meyrick, 1917) em dietas artificiais.}

Pôde-se observar que houve um alongamento do período larval de Tuta absoluta (Meyrick, 1917) quando o inseto foi criado em dietas artificiais, embora tenha havido uma variação muito grande entre as diferentes cultivares de feijão utilizadas (Tabela 3) .

A adição de extratos ou pós de folhas do tomateiro, mostrou que tais diferenças podem também estar relacionadas à falta de um fagoestimulante para o inseto, pois o acréscimo de pó de folhas encurtou em 11 dias o período larval em relação às piores dietas, ou seja aquelas à base de feijão Pintado ou Aeté, que, praticamente, triplicaram o período larval em relação à dieta natural. Isto leva à hipótese de que talvez não seja deficiência nutricional das dietas e que alguns ajustes nas características físicas destes meios (considerando-se o diminuto tamanho do insetol possam melhorar a sua "performance"; pode-se sugerir a trituração, com a moagem de ingredientes mais grosseiros como germe-de-trigo, o que 
possibilitará o preparo de uma dieta com textura mais adequada à traça-do-tomateiro.

Tabela 3 Duração dos períodos larval e pupal e peso de pupas de $T$. absoluta em 8 dietas artificiais e em dieta natural. Temperatura: $25 \pm 1^{\circ} \mathrm{C}$; UR: $70 \pm 10 \%$ f fotofase: $14 \mathrm{~h}$.

\begin{tabular}{cccc}
\hline Dieta & Periodo larval & Peso das & Periodo pupal \\
$(\star)$ & $($ dias $)\left({ }^{\star}\right)$ & pupas & $($ dias $)(\star \star)$
\end{tabular}

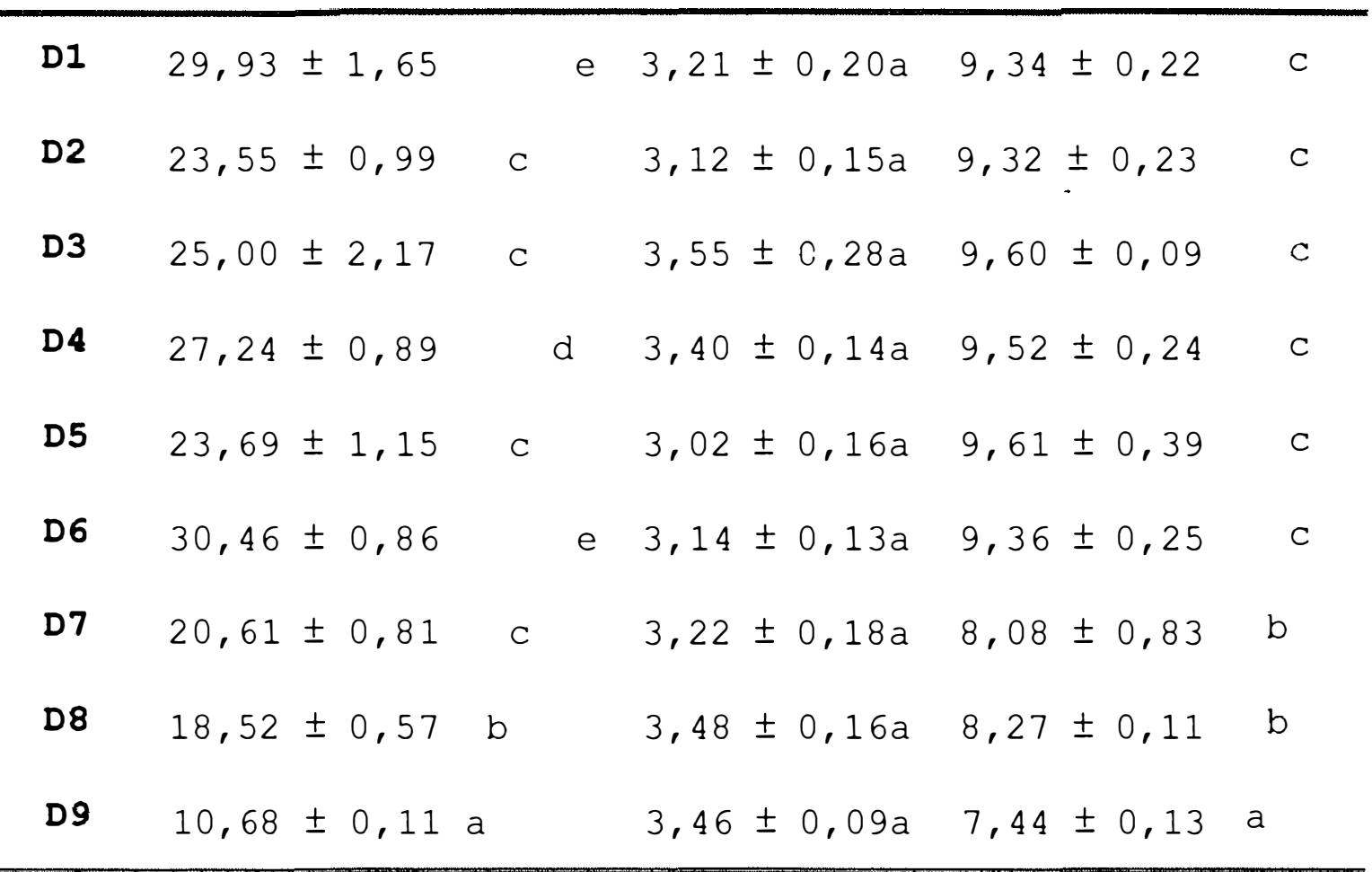

(*) D1: Dieta de Greene et al. (1976) com feijão Aeté; D2: Dieta de Greene et al. (1976) com feijão Branco; D3: Dieta de Greene et al. (1976) com feijão Carioca; D4: Dieta de Greene et al. (1976) com feijão Emgopa Ouro; D5: Dieta de Greene et al. (1976) com feijão Jalo; D6: Dieta de Greene et al. (1976) com feijão Pintado; D7: Dieta de Greene et al. (1976) con feijão Branco + extrato de folhas de tomateiro 'Santa Clara'; D8: Dieta de Greene et al. (1976) com feijão Branco + pó de foiha de tomateiro 'Santa Clara'; D9: Folha de tomateiro 'Santa Clara'

$\left({ }^{*}\right)$ Médias seguidas da mesma letra, nas colunas, não diferem entre si

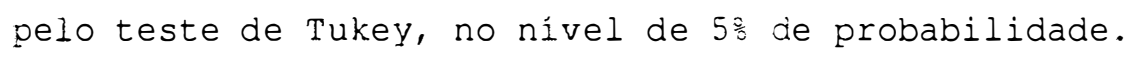


Os insetos estudados eram provenientes de folhas de tomateiro, o que pode ter levado a um condicionamento pré-imaginal. Desta forma, é provável que após algumas gerações no meio artificial, haja uma adaptação do inseto, visto que microlepidópteros da família Gelechiidae, em geral, somente se adaptam a meios artificiais após algumas gerações de laboratório (Singh, P., informação pessoal).

Ficou evidente, no entanto, a variação do desenvolvimento larval em função da cultivar de feijão utilizada.

o menor período larval foi obtido quando as lagartas foram criadas em folhas de tomateiro, cultivar 'Santa Clara', que é o alimento natural do inseto. Neste caso, os dados estão próximos àqueles obtidos por Razuri \& Vargas (1975) e Haji et al. (1988), porém são inferiores aos relatados por Imenes et al. (1990) e Vargas (1970. A duração do período larval com as cultivares Carioca, Jalo e Branco foi inferior aos resultados obtidos por Giustolin et al. (1995) em dietas artificiais.

Com relação à duração do período pupal, este foi menor para insetos criados em folhas de tomateiro, diferindo das dietas artificiais contendo unicamente feijão ou mesmo daquelas que continham feijão Branco enriquecido com extratos ou pó de folhas de tomateiro (Tabela 3).

Corroborando os resultados de Parra \& Carvalho (1984), para Spodoptera frugiperda (J.E.Smith, 1797), também para T. absoluta, aparentemente, o feijão branco, por possuir menos tanino e ser de fácil digestibilidade, acelerou o desenvolvimento inicial (fase 
larval) levando a um estresse do inseto que se reflete na fase seguinte, pois na presente pesquisa o maior período pupal foi obtido quando os insetos foram criados em dieta com feijão Branco (Tabela 3 ).

Indicando, mais uma vez, que não se trata de um problema nutricional, o peso de pupas não foi afetado pelas diferentes dietas (Tabela 3 ).

Quando a análise foi feita separadamente para machos e fêmeas, constatou-se que o alongamento do período larval nos insetos criados em dieta artificial se manteve, embora para insetos criados nas dietas contendo feijão 'Aeté' e 'Pintado' o período larval dos machos tenha sido um pouco mais longo (Tabelas 4 e 5), ocorrendo o inverso nas demais dietas.

Em geral, o peso das pupas que originaram fêmeas foi maior do que daquelas que originaram machos. Embora a literatura registre que existe uma estreita correlação entre o peso das pupas fêmeas e o número de ovos colocados, na presente pesquisa, o número de ovos foi bem superior quando o inseto foi criado em dieta natural (Tabela 6). Não existe explicação para este fato, visto que o peso de pupas fêmeas foi semelhante em todas as dietas, variando de 3,3 a 3,9 mg (Tabela 4).

O número de ovos obtido de fêmeas oriundas do hospedeiro natural (Tabela 6) foi superior ao encontrado por Herrera (1963), Paulo (1986), Haji et al. (1988) e Giustolin et al. (1995), estando próximo aos resultados encontrados por Razuri \& Vargas (1975) e souza et al. (1983). 


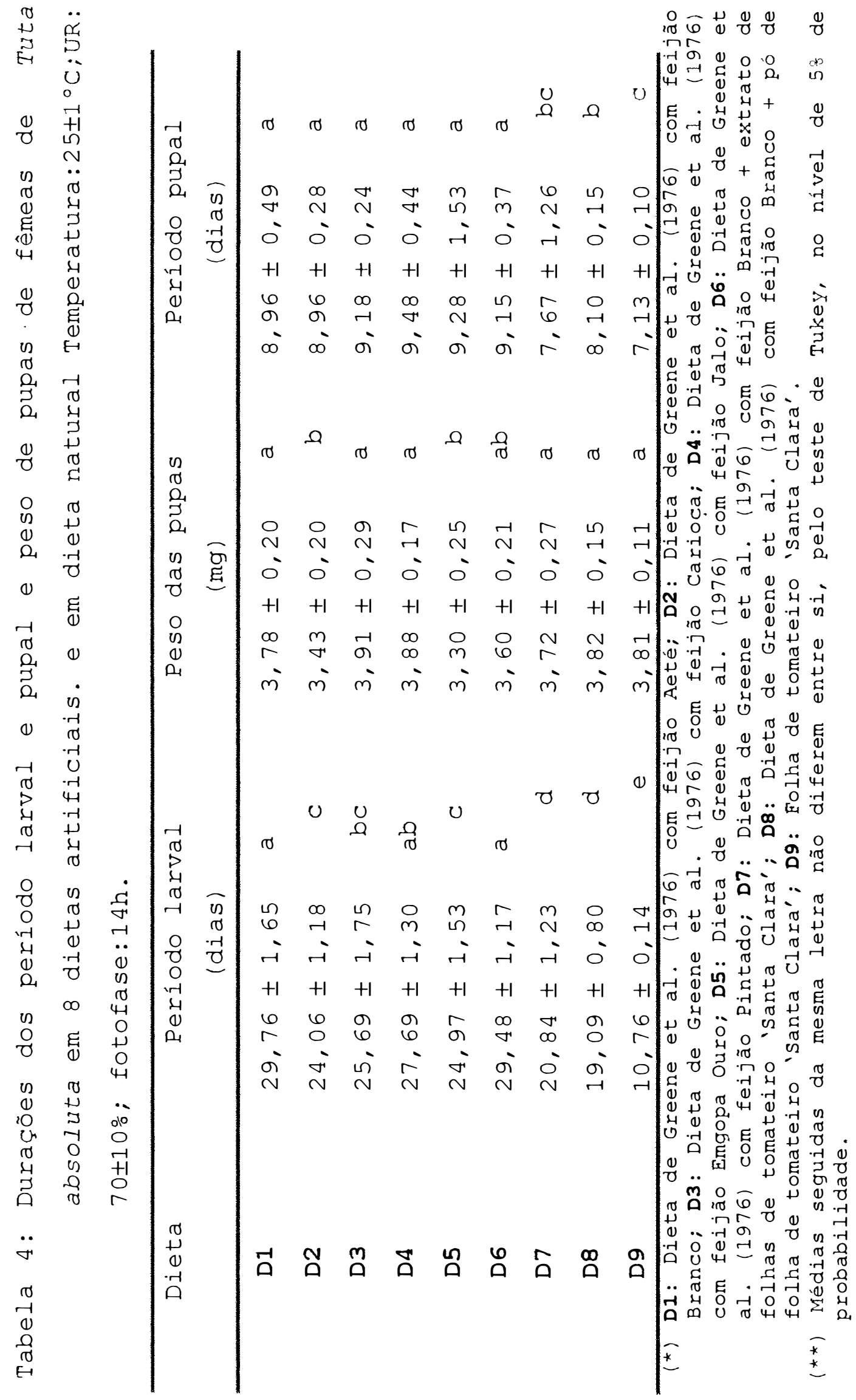




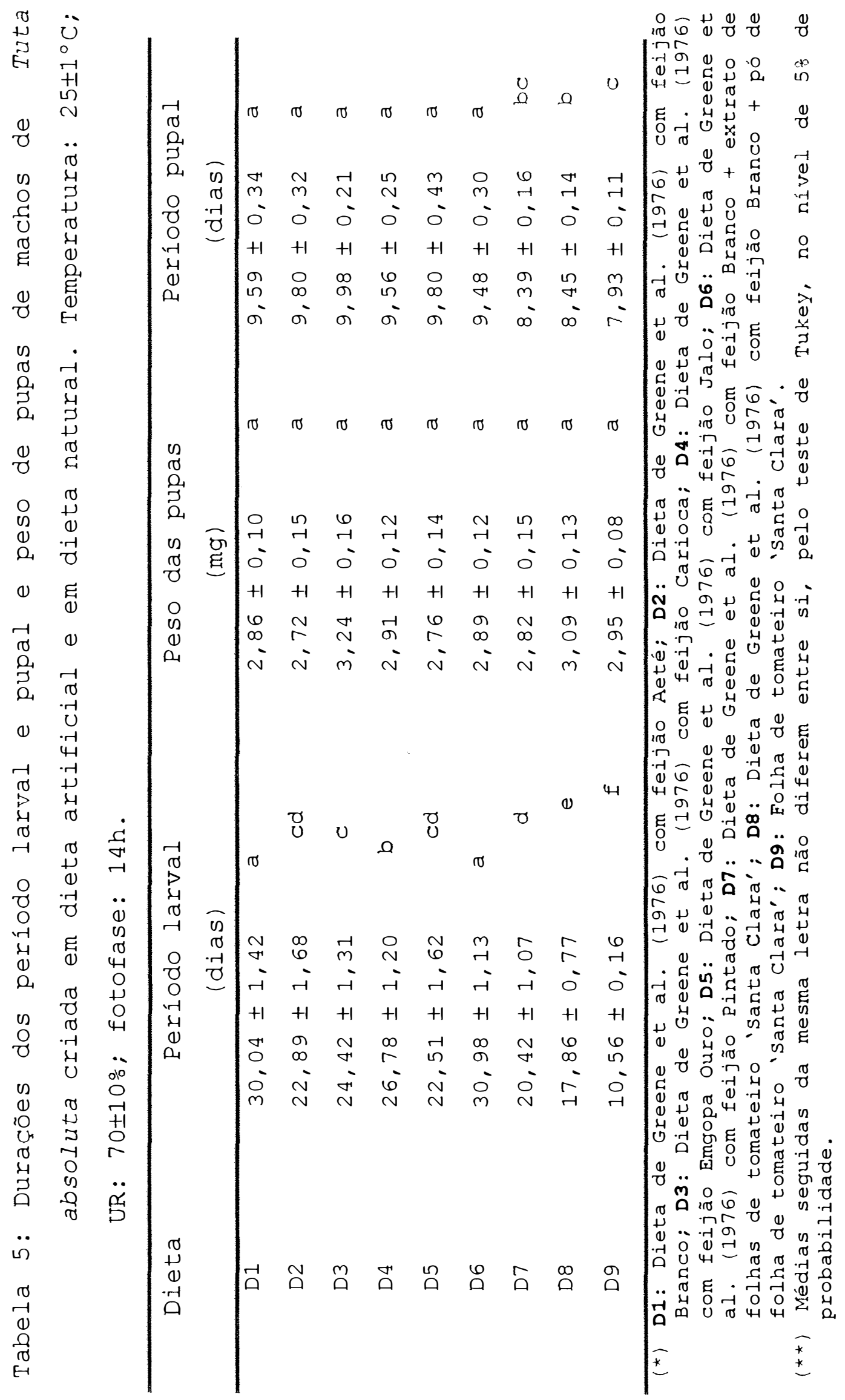


Tabela 6 Número médio de ovos colocados por $T$. absoluta criada em 8 dietas artificiais e em dieta natural. Temperatura: $25 \pm 1^{\circ} \mathrm{C}$; UR: $70 \pm 10 \%$; Fotofase: $14 \mathrm{~h}$.

\begin{tabular}{cccccc}
\hline Dieta & $\begin{array}{c}\text { Número médio de } \\
\text { ovos/fêmea/dieta }\end{array}$ & $(* *)$ & \multicolumn{2}{c}{ I.C. (5o $)$} \\
\hline D1 & $73,57 \pm 10,26$ & $b$ & 94,60 & 52,55 \\
D2 & $59,88 \pm 15,57$ & $b$ & 93,04 & 26,71 \\
D3 & $50,19 \pm 12,08$ & $b$ & 75,30 & 25,06 \\
D4 & $58,62 \pm 11,41$ & $b$ & 82,46 & 34,78 \\
D5 & $77,81 \pm 14,10$ & $b$ & 107,85 & 47,77 \\
D6 & $20,36 \pm 6,32$ & $b$ & 34,46 & 6,27 \\
D7 & $38,12 \pm 12,46$ & $b$ & 64,67 & 11,58 \\
D8 & $47,27 \pm 8,82$ & $b$ & 65,51 & 29,01 \\
D9 & $183,35 \pm 9,88$ & $a$ & 204,31 & 162,40
\end{tabular}

$\left.{ }^{\star}{ }^{\star}\right)$ D1: Dieta de Greene et al. (1976) com feijão Aeté; D2: Dieta de Greene et al. (1976) com feijão Branco; D3: Dieta de Greene et al. (1976) com feijão Carioca; D4: Dieta de Greene et al. (1976) com feijão Emgopa Ouro; D5: Dieta de Greene et al. (1976) com feijão Jalo; D6: Dieta de Greene et al. (1976) com feijão Pintado; D7: Dieta de Greene et al. (1976) com feijão Branco + extrato de folhas de tomateiro 'Santa Clara'; D8: Dieta de Greene et al. (1976) com feijão Branco + pó de folha de tomateiro 'Santa Clara'; D9: Folha de tomateiro 'Santa Clara'

$\left({ }^{\star}\right)$ Médias seguidas da mesma letra, nas colunas, não diferem entre si pelo teste de Tukey, no nível de $5 \%$ de probabilidade.

Porém, o resultado encontrado na presente pesquisa foi cerca de $1 / 3$ menor e $1 / 5$ maior quando comparado aos resultados obtidos por Imenes et al. (1990) com fêmeas alimentadas com mel a $10 \%$ e adultos que 
receberam apenas água, respectivamente. Fica evidente, tanto no presente trabalho como no dos referidos autores, a importância do fornecimento do mel para aumentar a postura e longevidade de insetos, como demonstrado para diversas espécies de Lepidoptera (Parra, 1996).

A criação da traça-do-tomateiro em dieta artificial afetou a sua longevidade (Tabela 7). Tanto machos quanto fêmeas viveram menos quando provenientes da dieta contendo feijão Branco acrescido de pó de folha de tomateiro, apesar da menor duração do período larval (Tabela 5) que foi conseguida quando se acrescentou este fagoestimulante na tentativa de aumentar $\circ$ "pegamento" inicial.

Não houve correlação entre longevidade e capacidade de postura quando foram consideradas dietas artificiais e naturais, pois quando criado em folhas de tomateiro, a fêmea viveu significativamente menos do que na dieta contendo feijão 'Jalo' e, no entanto, o número de ovos foi cerca de 2,5 vezes maior no hospedeiro natural do que na dieta artificial. Apesar da adição de pó de folhas ter reduzido a longevidade de T. absoluta (Tabela 7), ainda assim, a capacidade de postura destas fêmeas (Tabela 6) foi numericamente superior ao daquelas oriundas da dieta contendo feijão 'Pintado' .

A razão sexual foi significativamente alterada somente na dieta artificial que continha feijão 'Pintado', pois houve um maior número de machos do que de fêmeas. Este resultado atesta, mais uma vez, a inadequação desta cultivar para a criação da traça-do-tomateiro. Nas demais dietas, os valores obtidos não diferiram da condição 
Tabela 7 Razão sexual e longevidade média de machos e fêmeas de T. absoluta criados em 8 dietas artificiais e em dieta natural. Temperatura: $25 \pm 1{ }^{\circ} \mathrm{C}$; UR: $70 \pm 10 \%$; Eotofase: $14 \mathrm{~h}$.

\begin{tabular}{|c|c|c|c|c|c|}
\hline \multirow{3}{*}{$\begin{array}{c}\text { Dieta } \\
(\star)\end{array}$} & \multirow{3}{*}{$\frac{\text { Razão }}{\text { sexual }(* \star)}$} & \multicolumn{4}{|c|}{ Longevidade (dias) } \\
\hline & & \multicolumn{2}{|c|}{ machos $(\star \star \star)$} & \multicolumn{2}{|c|}{ fêmeas $(* \star \star)$} \\
\hline & & $13,32 \pm 0,77$ & $\mathrm{~b}$ & $13,68 \pm 0,80$ & $\mathrm{bc}$ \\
\hline D2 & 0,5698 & $12,81 \pm 1,15$ & $b$ & $13,12 \pm 0,98$ & bc \\
\hline D3 & 0,4592 & $13,09 \pm 0,92$ & $\mathrm{~b}$ & $12,54 \pm 0,92$ & $\mathrm{~b}$ \\
\hline D4 & 0,5048 & $13,00 \pm 0,84$ & $b$ & $13,14 \pm 0,72$ & $\mathrm{bc}$ \\
\hline D5 & 0,4776 & $14,31 \pm 1,02$ & $b$ & $16,62 \pm 0,81$ & C \\
\hline D6 & $0,3377(*)$ & $12,36 \pm 1,47$ & $a b$ & $14,36 \pm 1,20$ & $\mathrm{bc}$ \\
\hline D7 & 0,4493 & $10,12 \pm 0,77$ & $a b$ & $10,25 \pm 0,85$ & $\mathrm{bc}$ \\
\hline D8 & 0,5354 & $7,83 \pm 0,66$ & a & $7,70 \pm 0,59$ & a \\
\hline D9 & $0,5973(*)$ & $13,35 \pm 1,19$ & $b$ & $11,41 \pm 0,88$ & $b$ \\
\hline
\end{tabular}

(*) D1: Dieta de Greene et al. (1976) com feijão Aeté; D2: Dieta de Greene et al. (1976) com feijão Branco; D3: Dieta de Greene et al. (1976) com feijão Carioca; D4: Dieta de Greene et al. (1976) com feijão Emgopa Ouro; D5: Dieta de Greene et al. (1976) com feijão Jalo; D6: Dieta de Greene et al. (1976) com feijão Pintado; D7: Dieta de Greene et al. (1976) com feijão Branco + extrato de folhas de tomateiro 'Santa Clara'; D8: Dieta de Greene et al. (1976) com feijão Branco + pó de folha de tomateiro 'Santa Clara'; D9: Folha de tomateiro 'Santa Clara'.

(**) Valores seguidos pelo símbolo (*) diferem significativamente pelo teste do Qui-quadrado, no nível de $5 \%$ de probabilidade.

$(\star \star \star)$ Médias seguidas da mesma letra, nas colunas, não diferem entre si pelo teste de Tukey, no nível de $5 \%$ de probabilidade.

ideal de 50\% de fêmeas e 50\% de machos (razão sexual: 0,5) . Quando o inseto foi criado no hospedeiro natural, este valor foi significativamente diferente daquele normalmente 
esperado, pois obteve-se um número maior de fêmeas. O valor observado na presente pesquisa assemelha-se aos relatados por Vargas (1970), Haji et al.(1988) e Imenes et al.(1990).

A longevidade e a sobrevivência obedeceram à distribuição de Weibull, para machos e fêmeas, indicando que as dietas não alteraram a fisiologia do inseto, pois foi possivel fazer-se a previsão destes parâmetros, o que facilitará criações de laboratório, seja em pequena, média ou grande escala (Eiguras 5 e 6 ).

É sabido que, um dos grandes problemas na manutenção de criações em dietas artificiais, são as contaminações nos meios, já que estes são ricos em nutrientes, dando condições ideais para o desenvolvimento de microrganismos. Na presente pesquisa, a contaminação por fungos e bactérias nas dietas artificiais não existiu. Tal fato atesta a adequação da quantidade de anticontaminantes utilizada no preparo das dietas.

A viabilidade larval foi bastante reduzida quando o inseto foi criado em dietas artificiais em relação à dieta natural (Tabela 8). Dentre as dietas artificiais, a viabilidade do período larval foi maior naquela contendo feijão 'Branco' e pó de folha de tomateiro. O acréscimo de um fagoestimulante à dieta provocou um significativo aumento na viabilidade larval, evidenciando, mais uma vez, que o insucesso na obtenção de uma dieta artificial para a criação deste inseto, não está sendo provocado por um problema nutricional. 

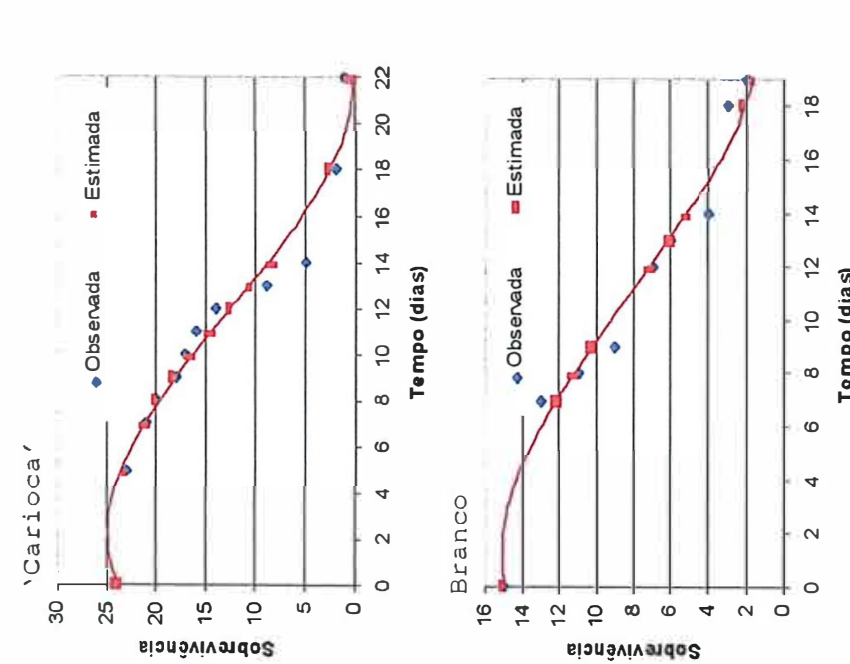

華 $\ddot{E}$

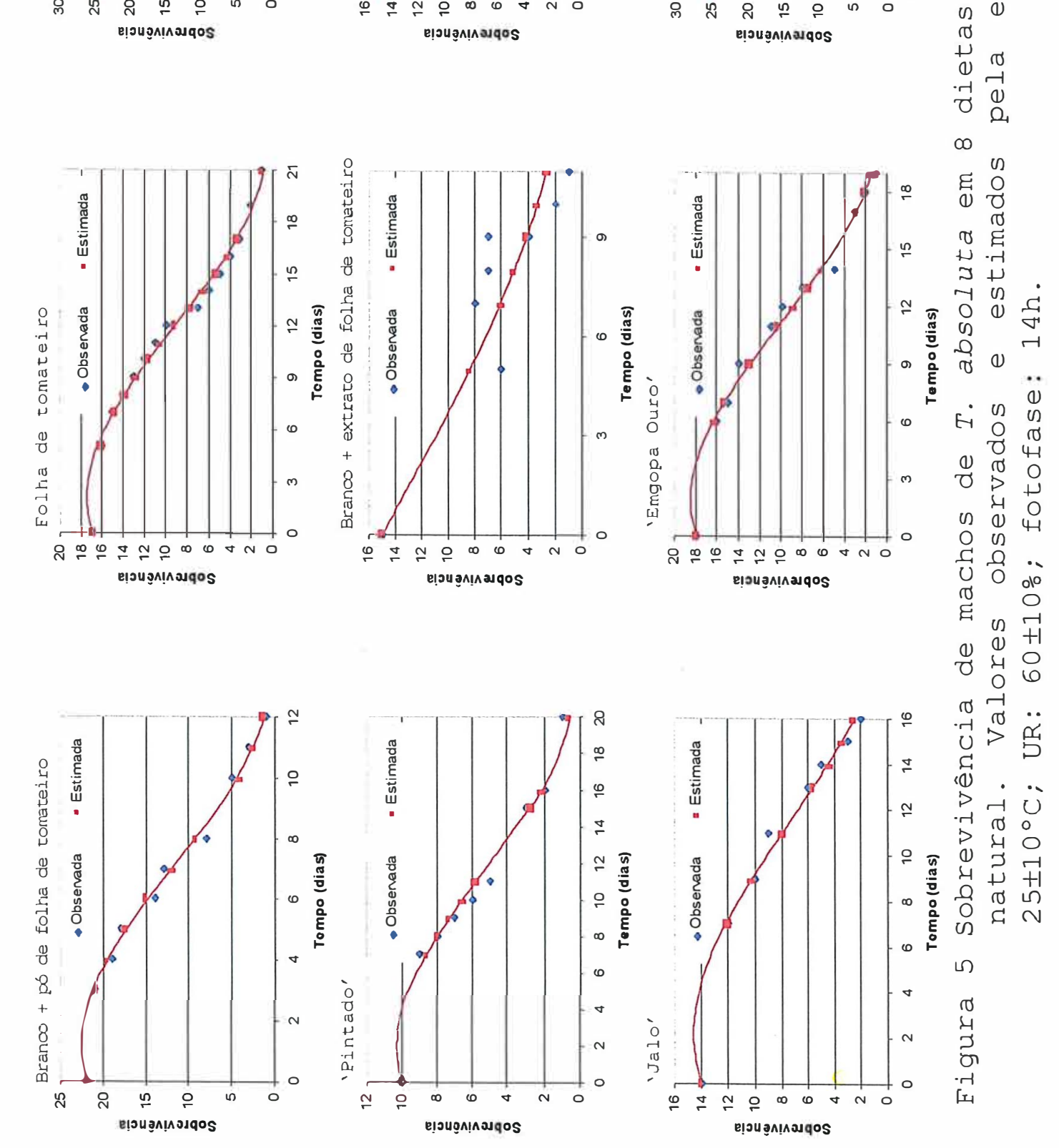



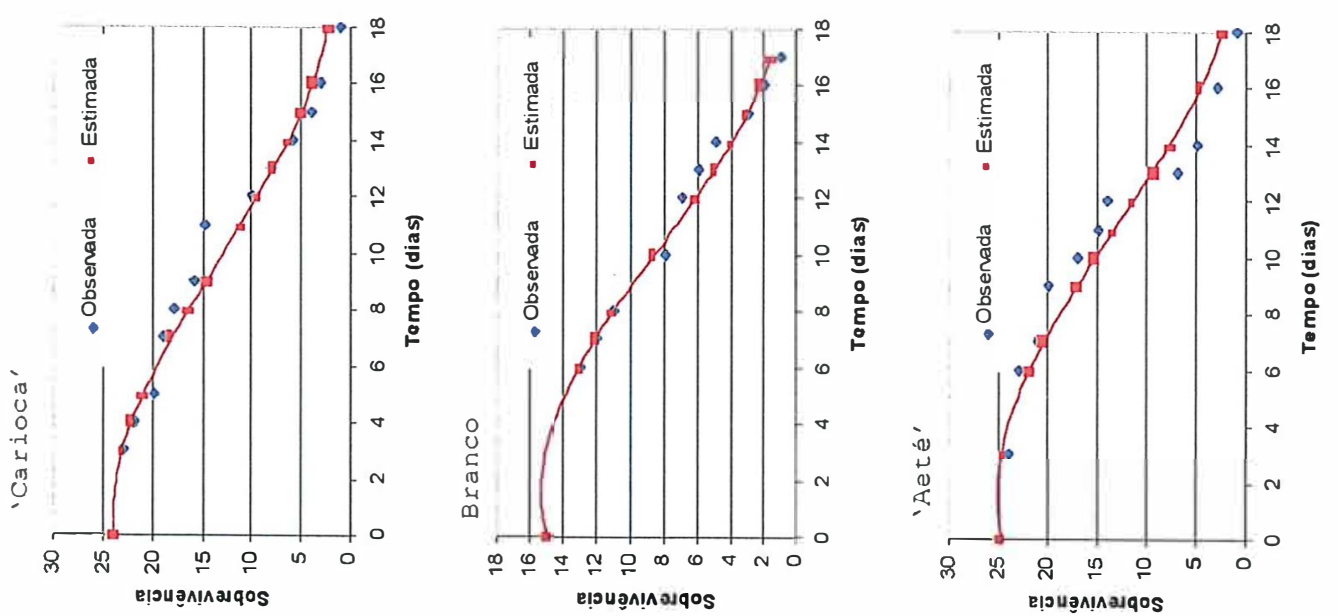

0
7
0
0
$\pi$
4
0
0
0
4
0
0
0
0
+
0
0
0
0
0
0
0

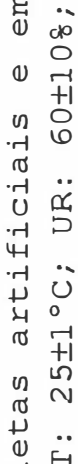

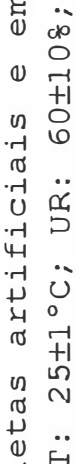

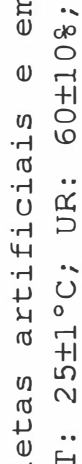
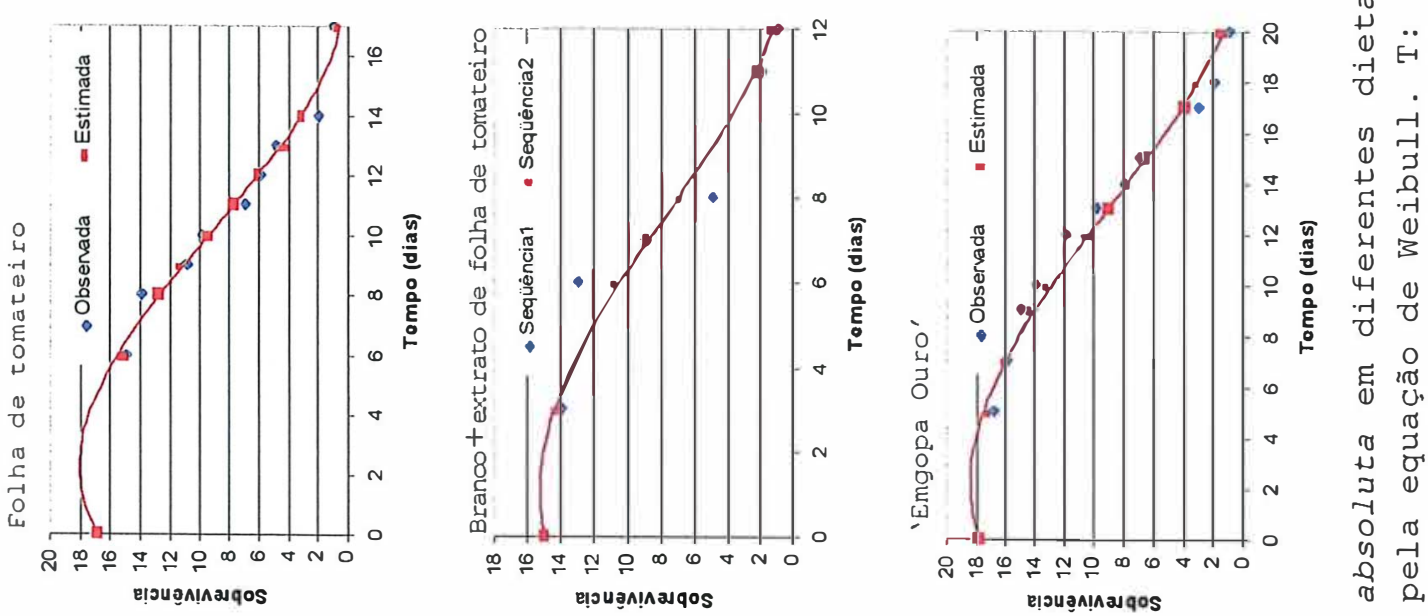

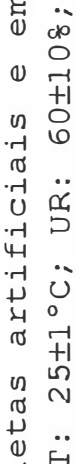

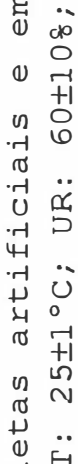

सi ?

ช) .
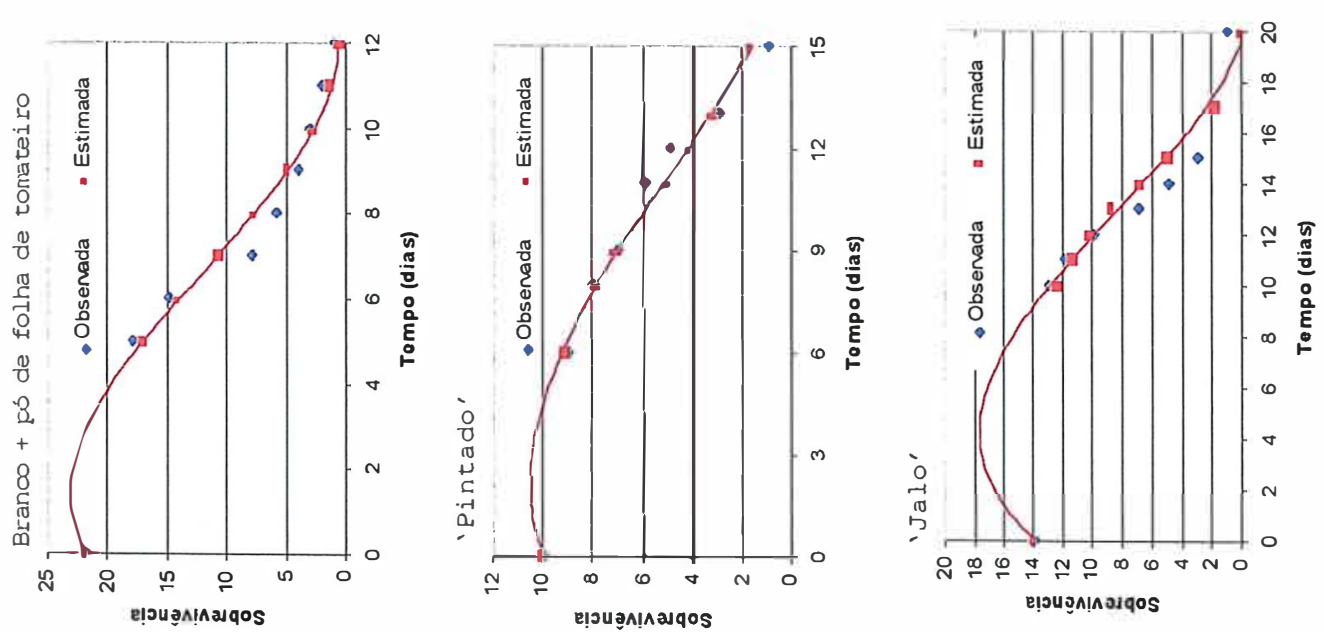

๑

r (1) 禹 $\begin{array}{ll}4 & 0 \\ 0 & 0 \\ 0 & 0\end{array}$ $7 \%$ . 14 U U (1) 0 $\rightarrow-10$ (1) 4 40 요 6
0
4
3
6
-7
.4 
Tabela 8 Viabilidade das fases larval, pupal, total e porcentagem de adultos não emergidos e deformados de $T$. absoluta em 8 dietas artificiais e em dieta natural. Temperatura: $25 \pm 1{ }^{\circ} \mathrm{C}$; UR: $70 \pm 10 \%$; Fotofase: $14 \mathrm{~h}$.

\begin{tabular}{|c|c|c|c|c|c|c|c|}
\hline \multirow{3}{*}{$\frac{\text { Dieta }}{\text { D1 }}$} & \multicolumn{5}{|c|}{ Viabilidade (\%) } & \multirow{3}{*}{$\begin{array}{c}\text { Adultos } \\
\text { Deformados } \\
\left(\frac{\circ}{\circ}\right) \\
3,45\end{array}$} & \multirow{3}{*}{$\begin{array}{c}\text { Não } \\
\text { emergidos } \\
\left(\frac{\circ}{0}\right) \\
10,34\end{array}$} \\
\hline & \multicolumn{2}{|c|}{ Larval } & \multirow{2}{*}{\multicolumn{2}{|c|}{$\frac{\text { Pupal }}{86,21 a}$}} & \multirow{2}{*}{$\frac{\text { Total }}{25,00}$} & & \\
\hline & 29,00 & $\mathrm{~cd}$ & & & & & \\
\hline D2 & 40,00 & C & 84,17 & a & 33,67 & 5,94 & 9,90 \\
\hline D3 & 32,67 & $c d$ & 78,57 & a & 25,67 & 6,12 & 15,31 \\
\hline D4 & 34,33 & $c d$ & 83,49 & $\mathrm{a}$ & 28,67 & 5,83 & 10,68 \\
\hline D5 & 23,33 & d & 79,10 & a & 18,33 & 2,99 & 17,91 \\
\hline D6 & 29,33 & $\mathrm{~cd}$ & 84,09 & $a$ & 24,67 & 6,82 & 9,09 \\
\hline D7 & 38.33 & $c d$ & 91,30 & a & 21,00 & --- & 8,70 \\
\hline D8 & 70,56 & $\mathrm{~b}$ & 89,76 & a & 63,33 & 0,79 & 9,45 \\
\hline D9 & 91,67 & & 89,09 & a & 81,67 & 3,27 & 7,64 \\
\hline
\end{tabular}

Greene et al. (1976) com feijão Branco; D3: Dieta de Greene et al. (1976) com feijão Carioca; D4: Dieta de Greene et al. (1976) com feijão Emgopa Ouro; D5: Dieta de Greene et al. (1976) com feijão Jalo; D6: Dieta de Greene et al. (1976) com feijão Pintado; D7: Dieta de Greene et al. (1976) com feijão Branco + extrato de folhas de tomateiro 'Santa Clara'; D8: Dieta de Greene et al. (1976) com feijão Branco + pó de folha de tomateiro 'Santa Clara'; D9: Folha de tomateiro 'Santa Clara'

$\left({ }^{*}\right)$ Médias seguidas da mesma letra, nas colunas, não diferem entre si pelo teste de Tukey, no nível de 5 \% de probabilidade. 
Provavelmente, o desempenho negativo do inseto no meio artificial está sendo causado por uma inadequação física, como por exemplo, a granulação (citada anteriormente) ou a quantidade de ágar (substância gelificante). O emprego de uma dieta mais liqüefeita, deverá facilitar a sobrevivência das lagartas de $1^{\circ}$ instar, que são de tamanho diminuto e bastante sensiveis ao desgaste provocado pelo consumo de um alimento muito rígido e áspero, e, muitas vezes, nem chegam a se alimentar. Por outro lado, a adição de pó de folhas de tomateiro, não favoreceram a longevidade de adultos e sua capacidade de postura (Tabelas 6 e 7 ); sugerem-se pesquisas no sentido de se determinar a concentração de pó de folha adequada a ser incorporada na dieta, desde que esta pode ter sido uma das causas deste insucesso, pois a concentração utilizada na presente pesquisa foi escolhida aleatoriamente.

Dentre as dietas artificiais que não receberam a adição de um fagoestimulante (pó ou extrato de folha de tomateirol, pode-se destacar aquela contendo apenas feijão Branco, com uma viabilidade larval de 40\%, sendo este valor numericamente superior aos demais obtidos (Tabela 8). Apesar de todos os valores serem inferiores àqueles preconizados por Singh (1983) para que uma dieta artificial seja considerada adequada para a criação de insetos, optou-se pela dieta com feijão Branco para dar continuidade ao trabalho, pois este tipo de feijão é facilmente encontrado no mercado brasileiro, além de ter proporcionado uma razoável capacidade de postura, longevidade de adultos comparável aos insetos criados em 
dieta natural e a maior viabilidade larval, em termos numéricos (Tabelas 6,7 e 8 ).

Por outro lado, não houve efeito das dietas artificiais na viabilidade pupal, sendo que aquelas contendo feijão Branco e pó ou extrato de folha proporcionaram viabilidades pupais, em termos numéricos, superiores àquelas registradas quando o inseto foi criado em dieta natural (Tabela 8), além de terem apresentado um número insignificante de adultos com deformações. Desta forma, supõe-se que a adaptação do inseto ao longo das gerações, permitirá que sejam atingidos os $75 \%$ de viabilidade total preconizados por Singh (i983) como o mínimo para que uma dieta possa ser utilizada para a criação de insetos em laboratório

Em linhas gerais, pelas características mencionadas, a dieta contendo feijão Branco e pó de folhas de tomateiro 'Santa Clara', pode ser colocada como a mais promissora para a criação de T. absoluta.

O número de ínstares larvais de T. absoluta foi constante e igual a 4 em todas as dietas artificiais testadas e no hospedeiro natural (folhas de tomateiro) (Tabela 9 e Figura 7 e 8). Tais dados são coincidentes com aqueles obtidos por Vargas (1970), Haji et al. (1988), Ferreira \& Anjos (1997) e Giustolin et al. (1997), que criaram os insetos em folhas de tomateiro. Em todas as dietas pôde-se observar que o crescimento da cápsula cefálica de todas as lagartas obedeceu à regra de Dyar (Parra \& Haddad, 1989), estando o valor da razão de crescimento entre 1,46 e 1,53. Estes valores estão próximos àqueles obtidos por Vargas (1970) e Haji et al. (1988) . 
Tabela : 9 Largura média da cápsula cefálica e razão de crescimento de $T$. absoluta criada em 8 dietas artificiais e em dieta natural. Temperatura: $25 \pm 1^{\circ} \mathrm{C} ; \mathrm{UR}: 70 \pm 10 \% ;$ Eotofase: $14 \mathrm{~h}$.

\begin{tabular}{|c|c|c|c|c|c|}
\hline \multirow[b]{2}{*}{ Dietas } & \multicolumn{5}{|c|}{$\begin{array}{c}\text { Ínstar } \\
\text { Largura da cápsula ce }\end{array}$} \\
\hline & $\omega_{0}$ & $2^{\circ}$ & $3^{\circ}$ & $4^{\circ}$ & $\begin{array}{c}\text { Razão de } \\
\text { crescimento }\end{array}$ \\
\hline D1 & 0,1451 & 0,2071 & 0,3244 & 0,4938 & 1,5053 \\
\hline D2 & 0,1460 & 0,2125 & 0,3338 & 0,5074 & 1,5155 \\
\hline D3 & 0,1461 & 0,2076 & 0,3137 & 0,4707 & $.1,4775$ \\
\hline D4 & 0,1476 & 0,2068 & 0,3148 & 0,4677 & 1,4697 \\
\hline D5 & 0,1446 & 0,2149 & 0,3345 & 0,5077 & 1,5154 \\
\hline D6 & 0,1464 & 0,2168 & 0,3235 & 0,5049 & 1,5113 \\
\hline D7 & 0,1483 & 0,2190 & 0,3239 & 0,4997 & 1,4995 \\
\hline D8 & 0,1488 & 0,2208 & 0,3325 & 0,5080 & 1,5059 \\
\hline D9 & 0,1412 & 0,2078 & 0,3274 & 0,5032 & 1,5278 \\
\hline
\end{tabular}

Greene et al. (1976) com feijão Branco; D3: Dieta de Greene et al. (1976) com feijão Carioca; D4: Dieta de Greene et al. (1976) com feijão Emgopa Ouro; D5: Dieta de Greene et al. (1976) com feijão Jalo; D6: Dieta de Greene et al. (1976) com feijão Pintado; D7: Dieta de Greene et al. (1976) com feijão Branco + extrato de folhas de tomateiro 'Santa Clara'; D8: Dieta de Greene et al. (1976) com feijão Branco + pó de folha de tomateiro 'Santa Clara'; D9: Folha de tomateiro 'Santa Clara' 

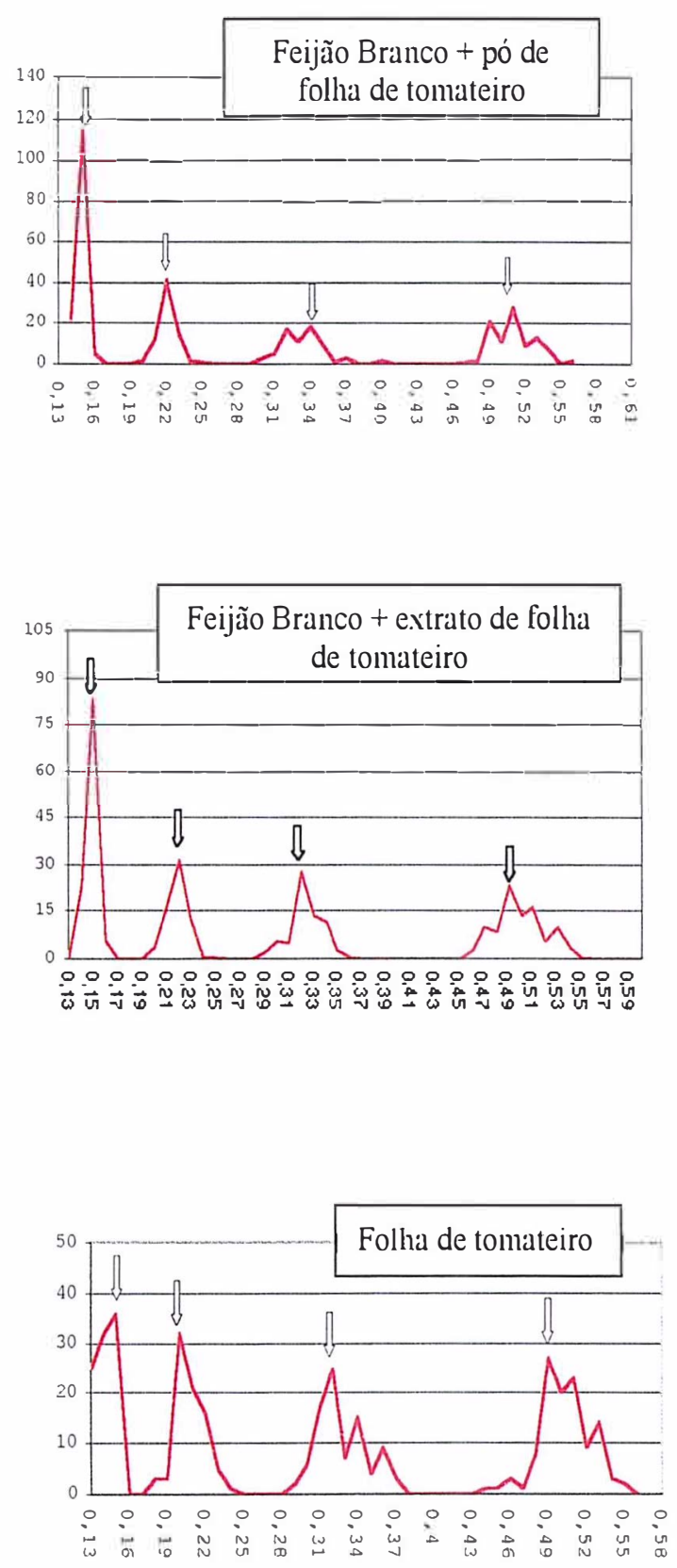

Figura 8 Curva de distribuição de freqüência de largura de cápsula cefálica de T. absoluta criada em 2 dietas artificiais e em dieta natural. As setas

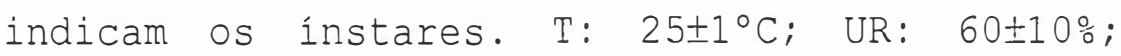
Fotofase: 14h. 
Apesar do número de ínstares não ter sido alterado pelos diferentes tipos de dietas, a sua duração foi bastante afetada. Assim, as lagartas alimentadas com folhas de tomateiro apresentaram ínstares com duração bastante curta, em torno de 2 dias cada um, completando o seu desenvolvimento larval em aproximadamente 11 dias (Tabela 10). Nas dietas artificiais, os instares sofreram um alongamento acentuado, o que provocou um período larval mais longo. Este alongamento foi mais evidente no $1^{\circ}$ ínstar e isto pode ser um reflexo da adaptação ao meio artificial, que contém componentes totalmente estranhos ao inseto que, originalmente se alimenta de folhas de tomateiro. Naquelas dietas em que se acrescentaram pó ou extrato de folhas de tomateiro, também observou-se um alongamento do $1^{\circ}$ ínstar, porém com uma aparente adaptação a seguir, que resultou em uma redução dos demais instares, com conseqüente reflexo na duração do período larval.

O aumento do número de ínstares pode ser um indicativo da inadequação nutricional de um meio alimentar (Parra, 1991). Como na presente pesquisa, este número no alimento natural e artificial foi constante e igual a 4, pode-se inferir que não há realmente problemas com as dietas, em termos nutricionais, podendo-se sugerir que os piores resultados nos meios artificiais se devem ou a problemas físicos da dieta ou à problemas de adaptação ao laboratório. 


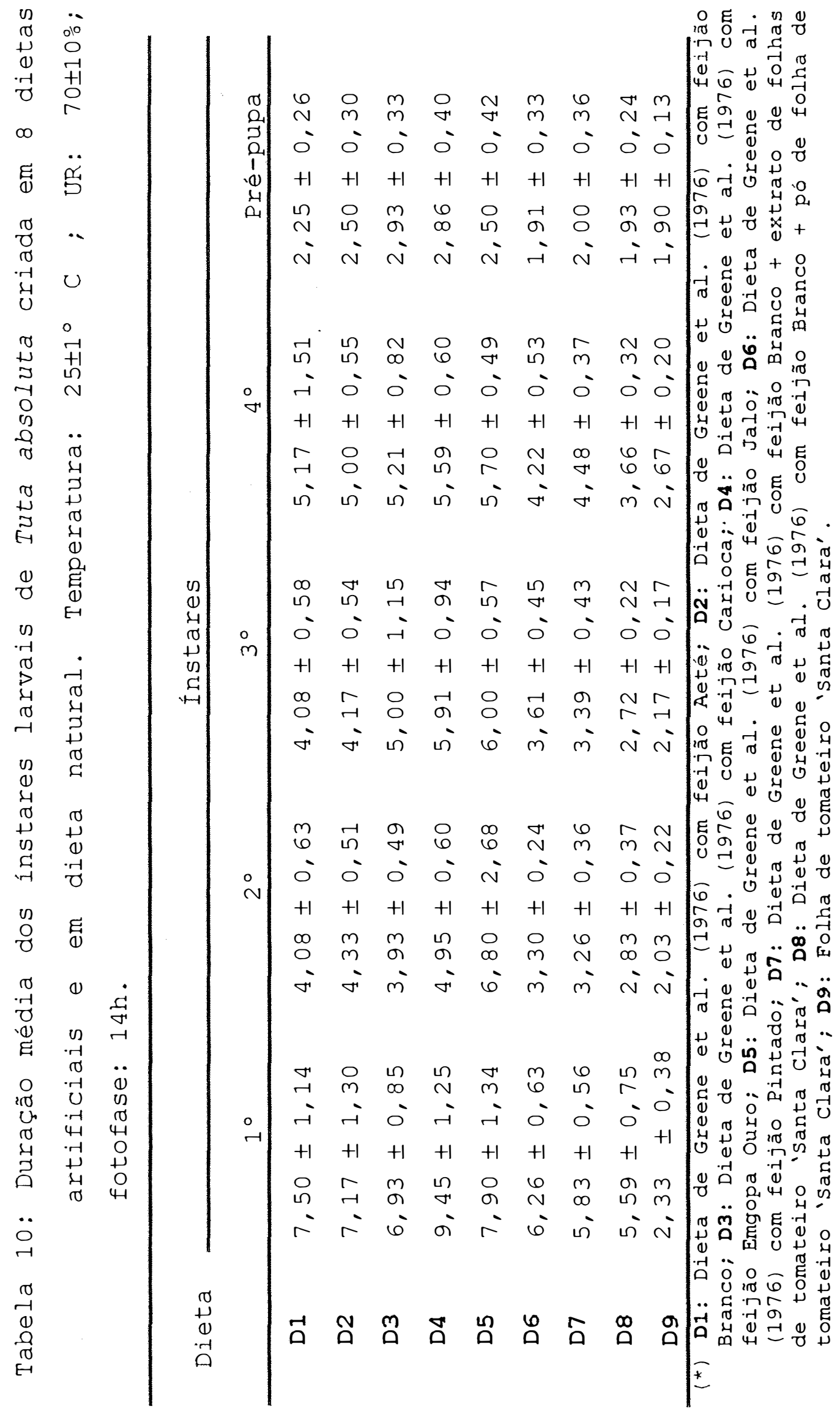




\subsection{Determinação do número ideal de lagartas de $T$. absoluta por tubo de criação.}

Após a seleção da dieta mais adequada para a criação de T. absoluta (item 4.1), procurou-se definir o número ideal de lagartas a ser "inoculado" por tubo de criação.

Com 20 lagartas/tubo, ocorreu um alongamento das fase larval (Tabela 11), indicando que o número ótimo está entre 16 e 20 individuos/tubo de criação, muito embora no número máximo colocado, a viabilidade total se manteve próxima ao valor obtido com 4 lagartas/recipiente de criação e o peso de pupas também se manteve igual àquele obtido nos outros tratamentos. Sugerem-se pesquisas por gerações sucessivas, baseando-se também em indices nutricionais para que possam ser definidos estes números ideais, fundamentais para a criação massal de qualquer inseto em laboratório.

A colocação de um grande número de individuos por recipiente de criação da traça-do-tomateiro é adequada, pois, aparentemente, não ocorreu competição intraespecífica pelo alimento e, até o presente, não foi constatada a ocorrência de canibalismo na espécie.

$$
\text { Sugerem-se novas pesquisas nesta direção, }
$$
desde que segundo Peters \& Barbosa (1977) existe um número ótimo de indivíduos por recipiente de criação dependendo da espécie de inseto. 
Tabela 11: Duração média dos períodos larval e pupal e peso de pupas de T. absoluta mantidas em dieta artificial com diferentes números de lagartas por tubo de criação. Temperatura: $25 \pm 1^{\circ} \mathrm{C}$; UR: $70 \pm 10 \% ;$ Fotofase: $14 \mathrm{~h}$.

\begin{tabular}{|c|c|c|c|c|c|c|}
\hline \multirow{2}{*}{$\begin{array}{c}\text { Número } \\
\text { de } \\
\text { lagarta } \\
\text { / tubo }\end{array}$} & \multirow{2}{*}{$\begin{array}{c}\text { Período } \\
\text { larval } \\
\text { (dias) } \\
\end{array}$} & \multirow{2}{*}{$\begin{array}{c}\text { Peso de } \\
\text { pupas } \\
(\mathrm{g})\end{array}$} & \multirow{2}{*}{$\begin{array}{c}\text { Período } \\
\text { pupal } \\
\text { (dias) } \\
\end{array}$} & \multicolumn{2}{|c|}{ Viabilidade } & \multirow{2}{*}{$\frac{(\%)}{\text { Total }}$} \\
\hline & & & & Larval & Pupal & \\
\hline 2 & $24,75 \pm 4,17$ & $3,31 \pm 0,43$ & $9,00 \pm 1,74$ & 40,0 & 62,5 & 25,0 \\
\hline 4 & $21,80 \pm 2,34$ & $3,33 \pm 0,32$ & $8,58 \pm 0,30$ & 37,5 & 80,0 & 30,0 \\
\hline 8 & $22,22 \pm 1,32$ & $3,20 \pm 0,32$ & $8,80 \pm 0,43$ & 37,5 & 74,1 & 23,8 \\
\hline 12 & $23,69 \pm 1,36$ & $3,00 \pm 0,21$ & $8,88 \pm 0,29$ & 35,0 & 61,9 & 21,7 \\
\hline 16 & $23,98 \pm 1,25$ & $3,30 \pm 0,19$ & $8,77 \pm 0,32$ & 37,5 & 72,9 & 21,9 \\
\hline 20 & $26,18 \pm 1,12$ & $3,40 \pm 0,20$ & $8,90 \pm 0,27$ & 38,5 & 91,8 & 29,0 \\
\hline
\end{tabular}

\subsection{Biologia da traça-do-tomateiro em diferentes}

\section{temperaturas.}

A duração do periodo embrionário de T. absoluta foi influenciada pelas variações de temperatura. Este periodo variou de 3,20 dias $\left(32^{\circ} \mathrm{C}\right)$ a 7,54 dias $\left(18^{\circ} \mathrm{C}\right)$, sendo decrescente neste intervalo (Tabela 12). Os valores obtidos são semelhantes àqueles relatados por Bentancourt et al. (1996), nas temperaturas de 30 e $25^{\circ} \mathrm{C}$ e inferior à temperatura de $20^{\circ} \mathrm{C}$. Quiroz (1976) referiu um período embrionário de 7 dias, na temperatura média de $14,5^{\circ} \mathrm{C}$, sendo este valor inferior àquele obtido no presente trabalho à $18^{\circ} \mathrm{C}$ e superior àquele conseguido à $20^{\circ} \mathrm{C}$. $\mathrm{O}$ 
$27^{\circ} \mathrm{C}$ é intermediário aos valores encontrados à 25 e $28^{\circ} \mathrm{C}$. Vargas (1970) estabeleceu um período embrionário médio de 6,7 dias à temperatura de $20,05^{\circ} \mathrm{C}$ e de 4,3 dias à $24,7^{\circ} \mathrm{C}$, sendo estes valores similares aos encontrados na presente pesquisa (Tabela 12).

A viabilidade dos ovos variou de $90,67 \%$ a $18^{\circ} \mathrm{C}$ a $76,67 \%$ a $32^{\circ} \mathrm{C}$ (Tabela 12). Entre os valores extremos, apesar de haver uma diferença numérica de 14\%, a significância estatística não existiu.

Tabela 12 Duração média do período embrionário e viabilidade dos ovos de T. absoluta em diferentes temperaturas. UR: 60土10\%; Fotofase: $14 \mathrm{~h}$.

\begin{tabular}{cccc}
$\begin{array}{c}\text { Temperatura } \\
\left({ }^{\circ} \mathrm{C}\right)\end{array}$ & $\begin{array}{c}\text { Duração } \\
\text { (dias) }\end{array}$ & $\begin{array}{c}\text { Viabilidade } \\
(\%)\end{array}$ \\
\hline 18 & $6.54 \pm 0.64$ & e & $90.67 \mathrm{a}$ \\
20 & $5.14 \pm 0.37 \quad \mathrm{c}$ & $88.67 \mathrm{a}$ \\
22 & $4.45 \pm 0.52 \mathrm{~b}$ & $86.00 \mathrm{a}$ \\
25 & $4.01 \pm 0.32 \mathrm{~b}$ & $81.33 \mathrm{a}$ \\
30 & $3.29 \pm 0.48 \mathrm{a}$ & $77.33 \mathrm{a}$ \\
32 & $3.20 \pm 0.42 \mathrm{a}$ & $74.67 \mathrm{a}$
\end{tabular}

Médias seguidas da mesma letra, nas colunas, não diferem entre si, pelo teste de Tukey, no nível de 5응 de probabilidade. 
Para a duração da fase larval da traça-dotomateiro, também ocorreu uma variação marcante em decorrência das temperaturas estudadas (Tabelas 13 e 14). Para as fêmeas, a menor duração foi conseguida quando o inseto foi criado à $30^{\circ} \mathrm{C}(18,71$ dias) e a maior, quando criada à $18^{\circ} \mathrm{C}(45,5$ dias $)$.

As pupas fêmeas de maior peso foram obtidas quando se criou 0 inseto à $25^{\circ} \mathrm{C}$, sem este valor diferir, no entanto, daquele obtido a 18 e $20^{\circ} \mathrm{C}$ (Tabela 13) e as mais leves foram obtidas a 28 e $30^{\circ} \mathrm{C}$, evidenciando uma nitida influência da temperatura sobre o peso do inseto sem, no entanto, haver uma correlação direta, pois o peśo das pupas obtidas à $22^{\circ} \mathrm{C}$ foi semelhante ao apresentado pelas pupas nas temperaturas de 28 e $30^{\circ} \mathrm{C}$.

A duração do período pupal também sofreu uma influência das diferentes temperaturas, sendo de 16 dias a sua duração à temperatura de $18^{\circ} \mathrm{C}$ e de apenas 7 dias à $30^{\circ} \mathrm{C}$.

A duração do período larval de machos de $T$. absoluta (Tabela 14) também foi influenciada pela temperatura. Este período oscilou entre 47 dias $\left(18^{\circ} \mathrm{C}\right)$ e 19 dias $\left(30^{\circ} \mathrm{C}\right)$, sendo decrescente a sua duração nas temperaturas compreendidas entre estes dois extremos. As pupas de menor peso $(2,6 \mathrm{mg})$ foram oriundas da temperatura de $28^{\circ} \mathrm{C}$ e as de maior peso $(3,2 \mathrm{mg})$ surgiram nas de 22 e $25^{\circ} \mathrm{C}$ (Tabela 14), não existindo, portanto, uma correlação direta entre o peso e as temperaturas. A duração do período pupal também sofreu influência direta das temperaturas, pois o maior período foi obtido à $18^{\circ} \mathrm{C}$ e o menor à $30^{\circ} \mathrm{C}$ (Tabela 14). 
Tabela 13 Duração dos períodos larval e pupal e peso de pupas fêmeas de $T$. absoluta criadas em dieta artificial e em diferentes temperaturas. UR: $60 \pm 10 \%$ : Fotofase: $14 \mathrm{~h}$.

\begin{tabular}{|c|c|c|c|c|}
\hline $\begin{array}{c}\text { Tempera } \\
\text { tura } \\
\left({ }^{\circ} \mathrm{C}\right) \\
\end{array}$ & $\begin{array}{c}\text { Periodo } \\
\text { larval } \\
\text { (dias) }\end{array}$ & & $\begin{array}{c}\text { Peso das } \\
\text { pupas } \\
(\mathrm{mg}) \\
\end{array}$ & $\begin{array}{c}\text { Periodo } \\
\text { Pupal } \\
\text { (dias) } \\
\end{array}$ \\
\hline 18 & $45,50 \pm 1,88$ & $d$ & $3,85 \pm 0,30 \quad b c$ & $16,05 \pm 0,76 \mathrm{c}$ \\
\hline 20 & $43,88 \pm 2,85$ & $c d$ & $3,51 \pm 0,23 a b c$ & $14,00 \pm 0,87 \mathrm{c}$ \\
\hline 22 & $40,92 \pm 3,44$ & c & $3,26 \pm 0,31 \mathrm{ab}$ & $13,40 \pm 0,55 \mathrm{bc}$ \\
\hline 25 & $25,45 \pm 1,13$ & & $3,86 \pm 0,23$ & $9,02 \pm 0,20 a b$ \\
\hline 28 & $23,41 \pm 1,41$ & & $3,26 \pm 0,27 \mathrm{ab}$ & $7,19 \pm 0,26 a$ \\
\hline 30 & $18,71 \pm 0,86$ & a & $3,15 \pm 0,26 \mathrm{ab}$ & $7,00 \pm 0,47 a$ \\
\hline
\end{tabular}

Médias seguidas da mesma letra, nas colunas, não diferem entre si pelo teste de Tukey, no nivel de $5 \%$ de probabilidade.

Tabela 14 Duração dos períodos larval e pupal e peso de pupas machos de T. absoluta em dieta artificial

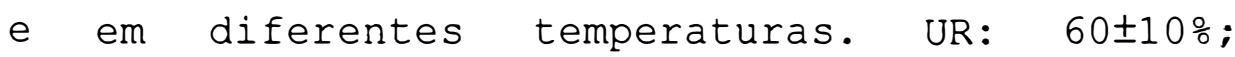
Eotofase: $14 \mathrm{~h}$.

\begin{tabular}{|c|c|c|c|c|}
\hline $\begin{array}{c}\text { Tempera } \\
\text { tura } \\
\left({ }^{\circ} \mathrm{C}\right)\end{array}$ & $\begin{array}{l}\text { Periodo } \\
\text { Larval } \\
\text { (dias) }\end{array}$ & & $\begin{array}{c}\text { Peso das } \\
\text { Pupas } \\
\text { (mg) }\end{array}$ & $\begin{array}{c}\text { Período } \\
\text { Pupal } \\
\text { (dias) }\end{array}$ \\
\hline 18 & $46,88 \pm 2,98$ & d & $3,03 \pm 0,24 \quad b c$ & $17,15 \pm 0,61$ \\
\hline 20 & $42,79 \pm 2.65$ & $c d$ & $3,19 \pm 0,20$ & $14,73 \pm 0,71$ \\
\hline 22 & $39,64 \pm 2.55$ & c & $2,89 \pm 0,17 \mathrm{abc}$ & $14,37 \pm 0,36$ \\
\hline 25 & $24,57 \pm 1.20 \mathrm{~b}$ & & $3,15 \pm 0,15$ & $9,54 \pm 0,24 k$ \\
\hline 28 & $22,47 \pm 0.94 \mathrm{~b}$ & & $2,53 \pm 0,18 \mathrm{a}$ & $7,70 \pm 0,28 a$ \\
\hline 30 & $18,79 \pm 1.07 a$ & & $2,72 \pm 0,20 \mathrm{ab}$ & $7,18 \pm 0,28 a$ \\
\hline
\end{tabular}

Médias seguidas da mesma letra, nas colunas, não diferem entre si pelo teste de Tukey, no nível de $5 \%$ de probabilidade. 
A $32^{\circ} \mathrm{C}$ não se conseguiu o desenvolvimento da traça-do-tomateiro em dieta artificial. Apenas 4 pupas se formaram e todas apresentavam-se deformadas. Desta forma, é de se supor que esta temperatura não seja adequada para o desenvolvimento larval do inseto em dieta artificial.

A capacidade de postura das fêmeas foi reduzida nas temperaturas (Tabela 15), sendo que não houve oviposição a $22^{\circ} \mathrm{C}$, apesar de se ter conseguido ovos nas temperaturas inferiores. O maior número de ovos foi obtido à $25^{\circ} \mathrm{C}(32,63$ ovos/fêmea), sendo este valor bastante inferior ao conseguido no item 4.1 da presente pesquisa, sem uma explicação aparente, pois, neste caso; o inseto já estava na $4^{\text {a }}$ geração de laboratório e, em função dos resultados de etapas anteriores, esperava-se que eles estivessem mais adaptados às condições artificiais.

A longevidade de adultos de T. absoluta também foi influenciada pelas temperaturas (Tabela 16). Tanto machos quanto fêmeas viveram mais à $18^{\circ} \mathrm{C}(21$ e 22 dias, respectivamente), enquanto que nas temperaturas superiores este valor foi bastante reduzido. Este resultado é justificado pela menor atividade metabólica do inseto em temperaturas mais baixas (Bleicher \& Parra, 1990).

O estudo da influência da temperatura nas diferentes fases de desenvolvimento, juntamente com a determinação de suas exigências térmicas, poderão auxiliar na elaboração de futuros modelos de simulação de ocorrência e zoneamento ecológico da traça-do-tomateiro, para o estabelecimento de opções de controle da praga. 
Tabela 15 Número médio de ovos por fêmea de $T$. absoluta criadas em dieta artificial e em diferentes

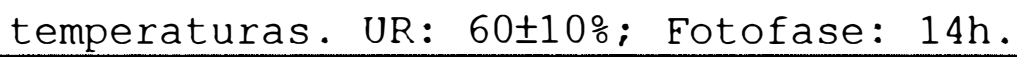

Temperatura Número médio de I.C. ( $5 \%)$

\begin{tabular}{cccc}
$\left({ }^{\circ} \mathrm{C}\right)$ & ovos & LS & LI \\
\hline 18 & $31,71 \pm 12,54$ & 58,80 & 4,63 \\
20 & $10,88 \pm 8,57$ & 31,10 & 0,00 \\
25 & $32,63 \pm 9,18$ & 51,91 & 13,35 \\
30 & $3,62 \pm 1,72$ & 7,69 & 0,00 \\
\hline
\end{tabular}

Tabela 16 Longevidade média de machos e fêmeas de $T$. absoluta criados em dieta artificial e em

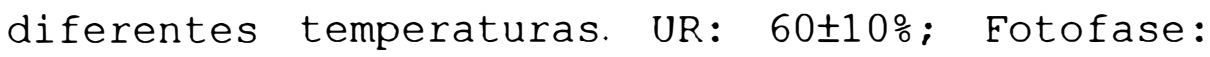
$14 \mathrm{~h}$.

\begin{tabular}{|c|c|c|c|c|}
\hline \multirow{3}{*}{$\frac{\text { Temperatura }}{18^{\circ} \mathrm{C}}$} & \multicolumn{4}{|c|}{ Longevidade (dias) } \\
\hline & \multicolumn{2}{|l|}{ Macho } & \multicolumn{2}{|l|}{ Fêmea } \\
\hline & $21.07 \pm 1.23$ & C & $22.14 \pm 1.25$ & C \\
\hline $20^{\circ} \mathrm{C}$ & $20,00 \pm 3,18$ & C & $15,50 \pm 2,36$ & $\mathrm{~b}$ \\
\hline $22^{\circ} \mathrm{C}$ & $11,00 \pm 1,31$ & $\mathrm{ab}$ & $12,12 \pm 1,42$ & $a b$ \\
\hline $25^{\circ} \mathrm{C}$ & $13,84 \pm 1,11$ & $\mathrm{~b}$ & $14,21 \pm 1,12$ & $\mathrm{~b}$ \\
\hline $28^{\circ} \mathrm{C}$ & $11,12 \pm 1,22$ & $a b$ & $9,75 \pm 1,19$ & $a b$ \\
\hline $30^{\circ} \mathrm{C}$ & $9,18 \pm 0,59$ & a & $9,58 \pm 0,95$ & a \\
\hline
\end{tabular}


Em todas as temperaturas, as curvas de sobrevivência dos adultos seguiram o modelo de distribuição de Weibull (Eiguras 9 e 10). Os valores dos parâmetros de forma (â) foram maiores do que 1,0 (um inteiro), evidenciando que a curva de sobrevivência é do tipo 1, ou seja, os adultos apresentaram uma taxa de mortalidade que aumentou com o tempo (Sgrillo, 1982).

\subsection{Determinação das exigências térmicas e número anual de gerações de Tuta absoluta.}

Baseando-se nas curvas de velocidade de desenvolvimento e nos valores obtidos para as durações das fases de desenvolvimento de T. absoluta em diferentes temperaturas (item 4.3), calcularam-se o limite térmico inferior de. desenvolvimento (Tb) e a constante térmica (K) desta praga.

A velocidade de desenvolvimento, em função da temperatura, ajustou-se ao modelo linear obtido através da recíproca da equação da hipérbole (Figura 11) (Haddad \& Parra, 1984).

Para a fase de ovo, a temperatura base estimada foi de $7,85^{\circ} \mathrm{C}$ e a respectiva constante térmica foi de 76,59 GD. O coeficiente de determinação foi de 98,19\%, bastante elevado, indicando a confiabilidade dos valores obtidos (Tabela 17 e Figura 11). 

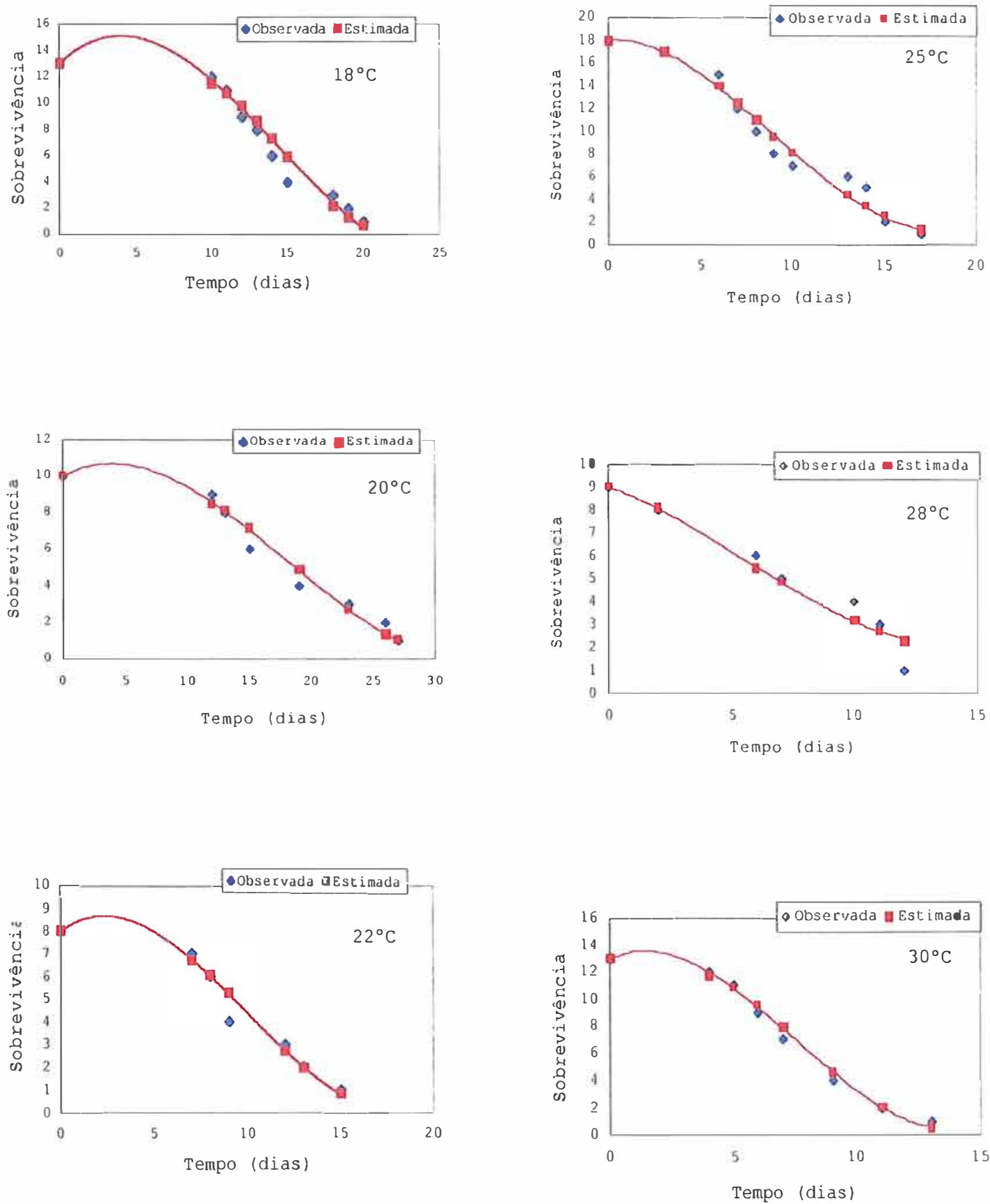

Figura 9 Sobrevivência de machos de T. absoluta criados em dieta artificial e em diferentes temperaturas. Valores observados e estimados pela equação de

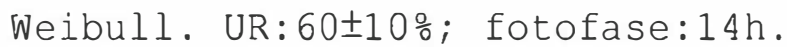



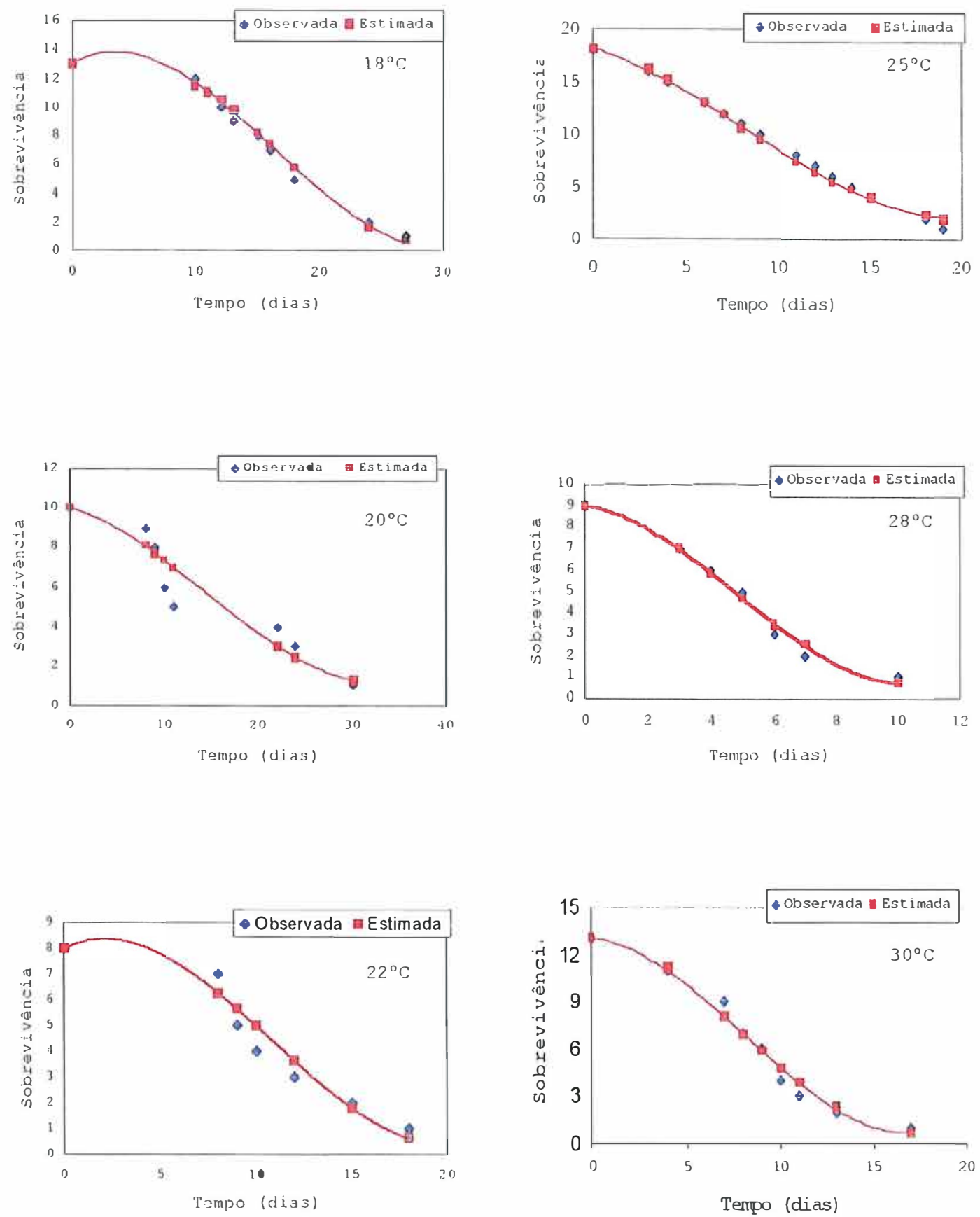

Figura 10 Sobrevivência de fêmeas de T. absoluta em dieta artificial e em diferentes temperaturas. Valores observados e estimados pela equação de Weibull. UR: $60 \pm 10 \%$; fotofase: $14 \mathrm{~h}$. 


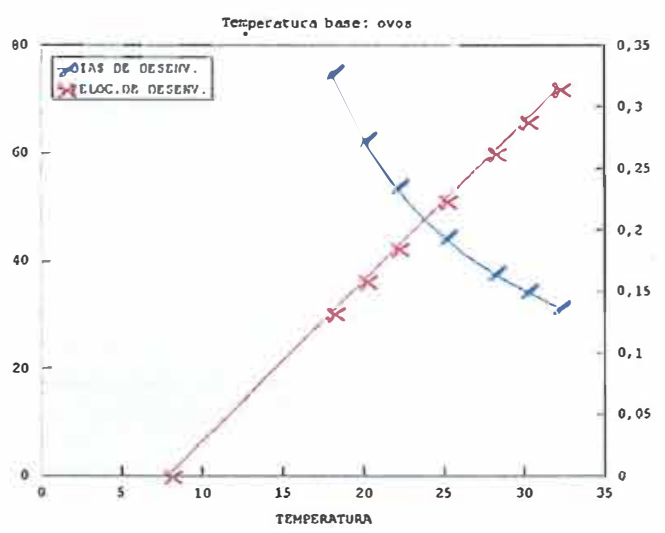

Teaperatura base: pupa (aAchos)
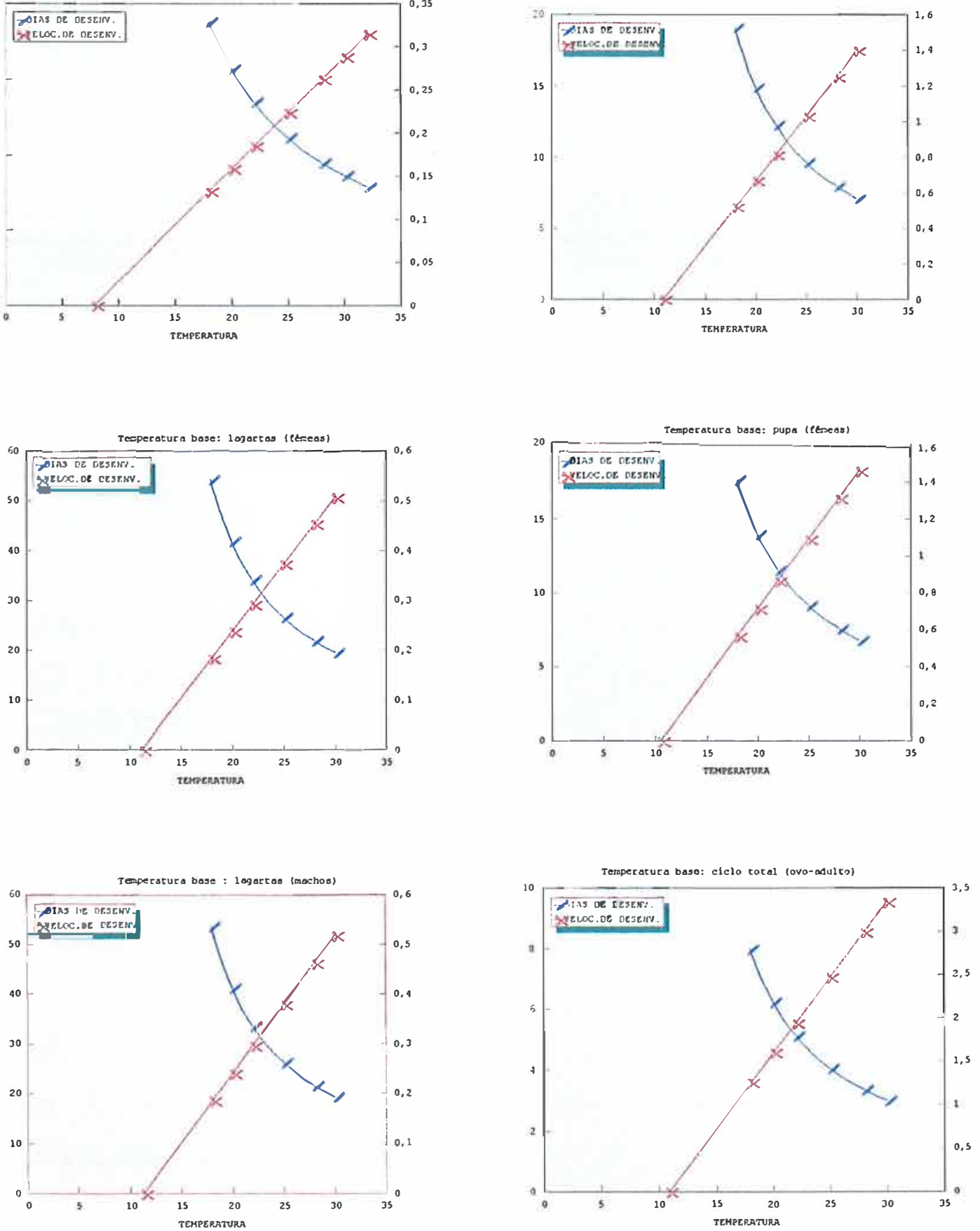

Figura 11 Curva de velocidade de desenvolvimento de T. absoluta criada em dieta artificial, em

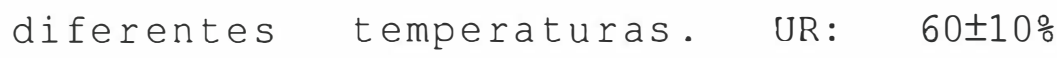
fotofase: $14 \mathrm{~h}$. 
Tabela 17 Temperatura base (Tb), constante térmica (K) e coeficiente de determinação $\left(R^{2}\right)$ de $T$. absoluta criada em dieta artificial e em diferentes temperaturas. UR: 60土10\%; Fotofase: $14 \mathrm{~h}$.

\begin{tabular}{cccc}
\hline $\begin{array}{c}\text { Fases do } \\
\text { desenvolvimento }\end{array}$ & $\begin{array}{c}\text { Temperatura } \\
\text { base } \\
\left({ }^{\circ} \mathrm{C}\right)\end{array}$ & $\begin{array}{c}\text { Constante } \\
\text { térmica } \\
\text { Ovo }\end{array}$ & $\begin{array}{c}\text { Coeficiente de } \\
\text { determinação }\end{array}$ \\
\hline lagarta (fêmea) & 11,17 & 76,59 & 98.19 \\
lagarta (macho) & 11,27 & 371,38 & 93.52 \\
pupa (fêmea) & 10,47 & 361,77 & 95.37 \\
pupa (macho) & 10,82 & 133,42 & 96.09 \\
ci.clo total (ovo- & 10,83 & 137,01 & 96.63 \\
adulto) & & 574,49 & 96,30 \\
\hline
\end{tabular}

A temperatura base, para o período larval das fêmeas, foi de $11,17^{\circ} \mathrm{C}$ com constante térmica de 371,38 GD, enquanto que para os machos estes valores foram $11,27^{\circ} \mathrm{C}$ e 361,77 GD, respectivamente (Tabela 17 e Figura 11), sendo, portanto, bastante próximos. Tais resultados indicam comportamento semelhante da fase larval de ambos os sexos, com relação à temperatura.

Para o período pupal de fêmeas, a temperatura base calculada foi $10,47^{\circ} \mathrm{C}$, com constante térmica de 133,42 GD e para os machos, os valores foram $10,82^{\circ} \mathrm{C}$ e $137,01 \mathrm{GD}$, respectivamente (Tabela 17 e figura 11). De forma análoga às lagartas, as pupas de machos e fêmeas têm exigências térmicas bastante próximas. Tais resultados indicam uma relação direta entre a nutrição e a 
fisiologia de insetos (Pádua et al., 1996), pois quando criado em folhas de tomateiro por Bentancourt et al. (1996), estes valores, para as fases de ovo e lagarta foram diferentes, ou seja, de 9,7 e $6,0^{\circ} \mathrm{C}$ para a temperatura base e de 72,2 e 267,1 GD para a constante térmica, respectivamente. Por outro lado, o meio nutricional não afetou as exigências térmicas da fase pupal, cujos valores foram próximos aos encontrados por Bentancourt et al. (1996), demonstrando que a dieta artificial, mesmo em diferentes temperaturas, não influenciou a duração do período pupal.

o provável número de gerações da praga ao longo do ano, em regiões do Estado de São Paulo, foi variável de 5,82 a 8,99 gerações, neste caso, em localidades onde a isoterma média anual é de $25^{\circ} \mathrm{C}$ (Tabela 18).

Considerando-se que a dieta artificial ainda não é a mais adequada para a criação de T. absoluta, vale ressaltar que o número de gerações obtido está subestimado. No entanto, os resultados ora encontrados, poderão servir como modelo para futuros estudos similares.

Tabela 18 Número provável de gerações por ano de Tuta absoluta criada em dieta artificial, em regiões do Estado de São Paulo com isotermas semelhantes.

\begin{tabular}{|c|c|}
\hline Isoterma $\left({ }^{\circ} \mathrm{C}\right)$ & Número de gerações \\
\hline 20 a 21 & 5,82 a 6,46 \\
\hline 21 a 22 & 6,46 a 7,09 \\
\hline 22 a 23 & 7,09 a 7,72 \\
\hline 23 a 24 & 7,72 a 8,36 \\
\hline 24 a 25 & 8,36 a 8,99 \\
\hline$>25$ & $>8,99$ \\
\hline
\end{tabular}




\subsection{Tabela de vida de fertilidade}

O valor de Ro (número de vezes qué a população aumenta a cada geração) foi maior quando o inseto foi criado em folha de tomateiro. Dentre as dietas artificiais, o maior valor de Ro foi obtido na dieta contendo feijão Branco + pó de folha de tomateiro e o menor valor na dieta com feijão 'Pintado'. Assim, a cada geração, a traça-do-tomateiro, alimentada com folhas do hospedeiro natural aumentará 72,28 vezes; quando alimentada com dieta artificial com feijão Branco + pó de folha aumentará 13,55 vezes, enquanto que aquela alimentada com dieta à base de feijão 'Pintado', aumentará apenas 1,51 vezes (Eigura 12 e Tabela 19).

A razão infinitesimal de aumento populacional (rm) (Eigura 13 e Tabela 19) mostra que o crescimento foi maior nos insetos que se alimentaram de folhas de tomateiro. No caso das dietas artificiais, este valor foi maior para a dieta que continha feijão Branco acrescido de pó de folha. Segundo Rabinovich (1978), rm é um parâmetro geneticamente determinado, intrínseco da espécie, que reflete na . capacidade potencial de multiplicação da população e, desta forma, a expressão do potencial biótico da população da traça-do-tomateiro foi superior na dieta natural (folhas de tomateiro); pelos resultados obtidos, ficou evidenciada a possibilidade de se criar o inseto nas dietas artificiais. Como a pesquisa foi realizada apenas por 1 geração, recomendam-se estudos por gerações sucessivas para que os insetos se adaptem ao meio e possam, então, realmente refletir os efeitos das dietas analisadas. 


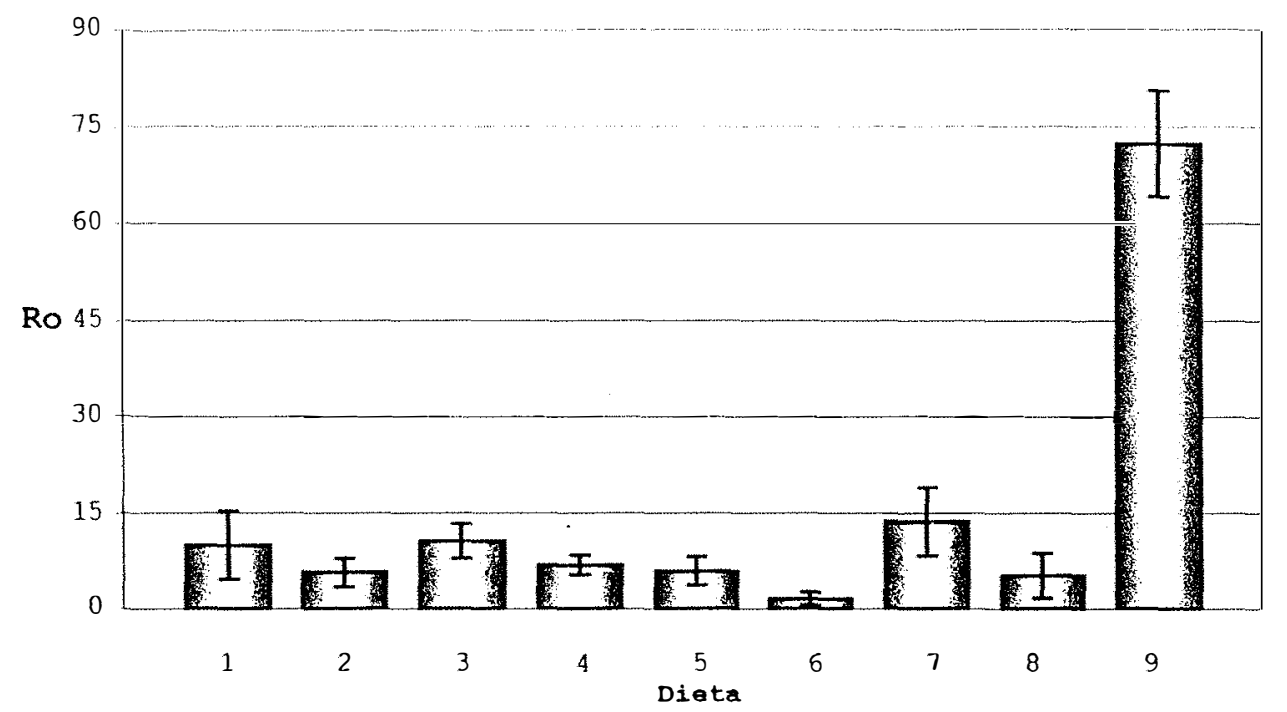

(*)D1:Dieta de Greene et al.(1976) com feijão Branco; D2: Dieta de Greene.et.al.(1976) com feijão 'Carioca'; D3: Dieta de Greene et al.(1976) com feijăo 'Emgopa Ouro'; D4: Dieta de Greene et al.(1976) com feijăo 'Aeté'; D5: Dieta de Greene et al. (1976) com feijăo 'Jalo'; D6: Dieta de Greene et al.(1976) com feijão 'Pintado'; D7: Dieta de Greene et al.(1976) com feijăo Branco + pó de folha de folha de tomateiro 'Santa Clara'; D8: Dieta de Greene et al.(1976) com feijåo Branco + extrato de folha de tomateiro 'Santa Clara; D9: folha de tomateiro 'Santa Clara'.

Figura 12 Taxa líquida de reprodução (Ro) de Tuta absoluta criada em 8 dietas artificiais e em dieta natural. As barras $(\perp$ e $\perp)$ representam 0 intervalo de confiança de 95\%. Temperatura: $25 \pm 1{ }^{\circ} \mathrm{C} ;$ UR: $70 \pm 10 \%$; fotofase: $14 \mathrm{~h}$. 


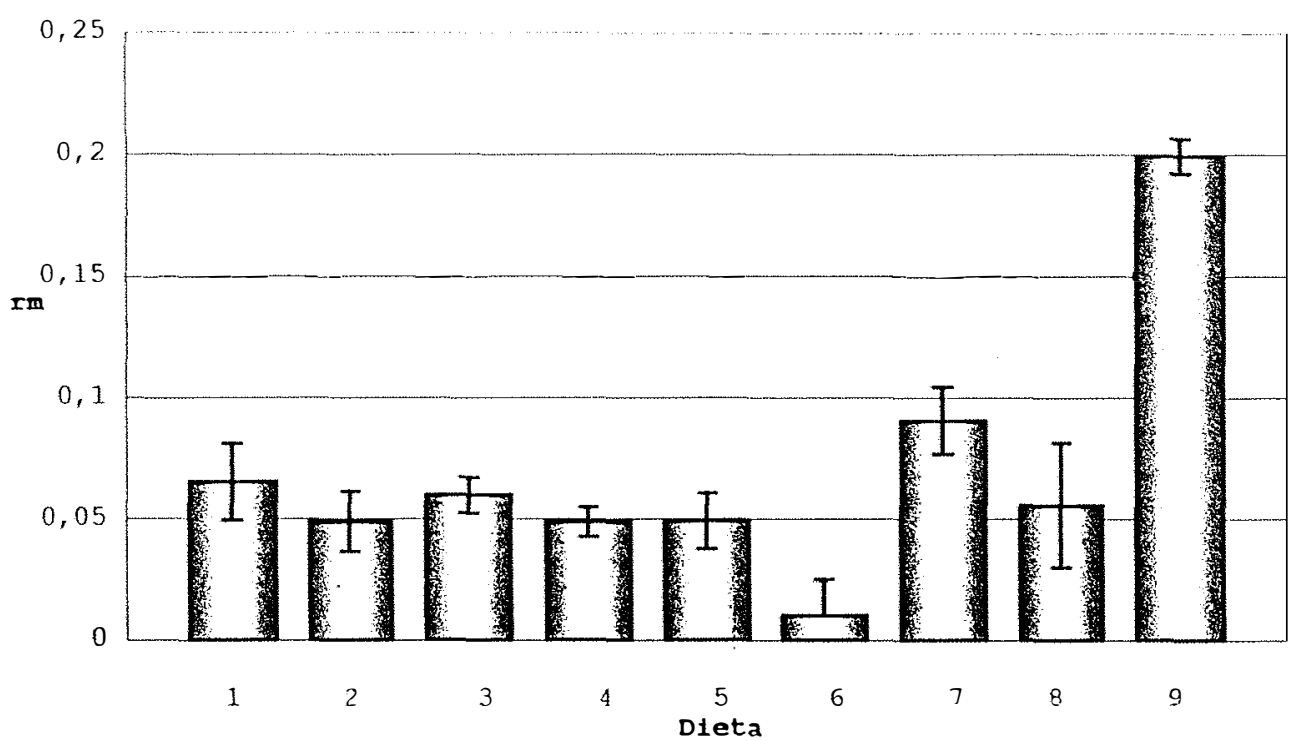

(*)D1:Dieta de Greene et al.(1976) com feijåo Branco; D2: Dieta de Greene.et.al.(1976) com feijåo 'Carioca'; D3: Dieta de Greene et al.(1976) com feijåo 'Emgopa Ouro'; D4: Dieta de Greene et al.(1976) com feijăo 'Aeté'; D5: Dieta de Greene et al. (1976) com feijăo 'Jalo'; D6: Dieta de Greene et al.(1976) com feija̋o 'Pintado'; D7: Dieta de Greene et al.(1976) com feijåo Branco + pó de folha de folha de tomateiro 'Santa Clara'; D8: Dieta de Greene et al.(1976) com feijåo Branco + extrato de folha de tomateiro 'Santa Clara; D9: folha de tomateiro 'Santa Clara'.

Eigura 13 Razão infinitesimal de aumento ( $\mathrm{rm}$ ) de $T$. absoluta criada em 8 dietas artificiais e em dieta natural. As barras $(\perp$ e $T)$ representam 0 intervalo de confiança de $95 \%$. T: $25 \pm 1^{\circ} \mathrm{C} ; \mathrm{UR}$ : $70 \pm 10 \% ;$ fotofase: $14 \mathrm{~h}$.

O período médio de uma geração (T) também foi menor para aqueles insetos criados em folhas de tomateiro (Tabela 19 e Figura 14). Entre as dietas artificiais, os menores valores foram encontrados quando os insetos foram alimentados com dieta de feijão Branco acrescido de pó ou extrato de folha de tomateiro; tais resultados indicam, mais uma vez, que existem condições de 
se multiplicar a traça-do-tomateiro em meios artificiais. Quando o inseto foi criado na dieta com feijão 'Pintado' o valor de $\mathrm{T}$ duplicou, em relação à dieta natural, demonstrando a inadequação desta cultivar para a criação de T. absoluta.

Tabela 19 Parâmetros associados à tabela de vida de fertilidade de $T$. absoluta criada em 8 dietas artificiais e em dieta natural. Temperatura: $25 \pm 1{ }^{\circ} \mathrm{C} ;$ UR: $70 \pm 10 \%$; fotofase: $14 \mathrm{~h}$.

\begin{tabular}{|c|c|c|c|c|c|}
\hline $\begin{array}{c}\text { Dieta } \\
(\star)\end{array}$ & Ro $(* \star)$ & $\sin (* \star)$ & $\lambda(\star \star)$ & $T(\star \star)$ & $\operatorname{Td}(* \star)$ \\
\hline D1 & $9,88 \mathrm{bc}$ & $0,064 \quad c$ & $1,067 \quad c$ & $35,61 \mathrm{~b}$ & $10,49 a$ \\
\hline D2 & $5,68 \quad c$ & 0,048 & $1,083 \quad c$ & $35,97 \mathrm{~b}$ & $13,97 a$ \\
\hline D3 & $10,56 \mathrm{~b}$ & 0,060 & $1,062 \quad \mathrm{c}$ & $39,58 \mathrm{~b}$ & $11,57 a$ \\
\hline D4 & $6,83 \quad c$ & 0,049 & $1,050 \quad c$ & $39,52 \mathrm{~b}$ & $14,17 a$ \\
\hline D5 & $5,89 \quad c$ & 0,049 & $1,050 \quad c$ & $36,43 \mathrm{~b}$ & $13,97 a$ \\
\hline D6 & 1,51 & 0,001 & 1,010 & $46,03 \mathrm{a}$ & - - - - \\
\hline D7 & $13,55 \mathrm{~b}$ & $0,090 \quad b$ & $1,095 \mathrm{~b}$ & $29,00 \quad c$ & $7,62 \mathrm{~b}$ \\
\hline D8 & $5,10 \quad c$ & $0,054 \quad \mathrm{~cd}$ & $1,057 \quad c$ & $30,18 \quad c$ & $11,74 a$ \\
\hline D9 & $72,28 a$ & $0,199 a$ & $1,220 a$ & $21,50 \quad d$ & $3,48 \quad c$ \\
\hline
\end{tabular}

(*)D1:Dieta de Greene et al.(1976) com feijão Branco; D2: Dieta de Greene et al.(1976) com feijão 'Carioca'; D3: Dieta de Greene et al.(1976) com feijão 'Emgopa Ouro'; D4: Dieta de Greene et al.(1976) com feijão 'Aeté'; D5: Dieta de Greene et al.(1976) com feijão 'Jalo'; D6: Dieta de Greene et al.(1976) com feijão 'Pintado'; D7: Dieta de Greene et al.(1976) com feijão Branco + pó de folha de folha de tomateiro 'Santa Clara'; D8: Dieta de Greene et al.(1976) com feijão Branco + extrato de folha de tomateiro 'Santa Clara; D9: folha de tomateiro 'Santa Clara'.

(**) Médias seguidas da mesma letra não diferem entre si, pelo teste $t$, com estimativa da variância calculada pelo método jackknife. 


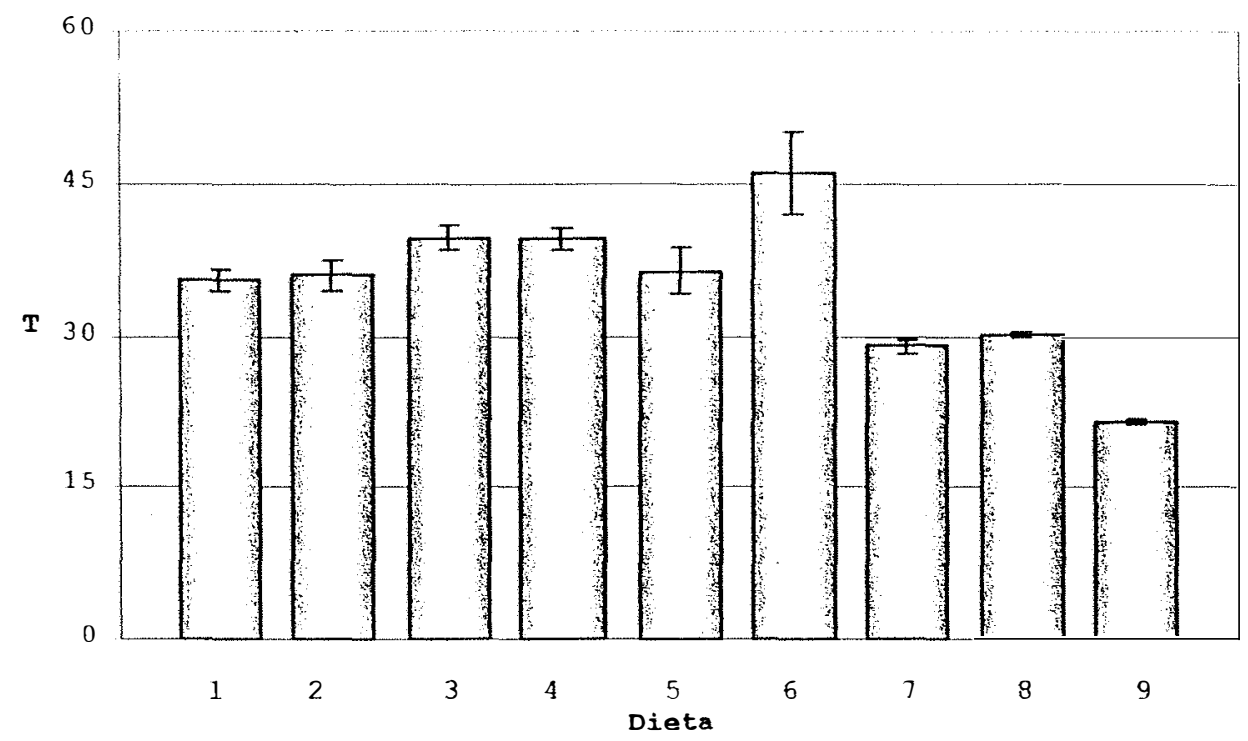

(*)D1:Dieta de Greene et al.(1976) com feijão Branco; D2: Dieta de Greene.et.al.(1976) com feijão 'Carioca'; D3: Dieta de Greene et al.(1976) com feijão 'Emgopa Ouro'; D4: Dieta de Greene et al.(1976) com feijão 'Aeté'; D5: Dieta de Greene et al.(1976) com feijão 'Jalo'; D6: Dieta de Greene et al.(1976) com feijão 'Pintado'; D7: Dieta de Greene et al.(1976) com feijão Branco + pó de folha de folha de tomateiro 'Santa Clara'; D8: Dieta de Greene et al.(1976) com feijão Branco + extrato de folha de tomateiro 'Santa Clara; D9: folha de tomateiro 'Santa Clara'.

Figura 14 Intervalo médio entre gerações (T) de T. absoluta criada em 8 dietas artificiais e em dieta natural. As barras $(\perp$ e $T)$ representam 0 intervalo de confiança de 95\%. Temperatura: $25 \pm 1{ }^{\circ} \mathrm{C} ; \mathrm{UR}: 70 \pm 10 \%$; fotofase: $14 \mathrm{~h}$.

A razão finita de aumento $(\lambda)$, ou seja, o número de fêmeas adicionadas à população por fêmea por unidade de tempo foi maior para a dieta natural (folha de tomateirol e o menor valor foi obtido para a dieta contendo feijão 'Pintado' (Tabela 19 e Figura 15). No caso da dieta contendo feijão Branco com pó de folha de tomateiro, podese dizer que a cada dia são acrescentadas à população 5,7 \% 
de fêmeas e para aquela com feijão 'Pintado' apenas 1\% de fêmeas será acrescentado ao dia.

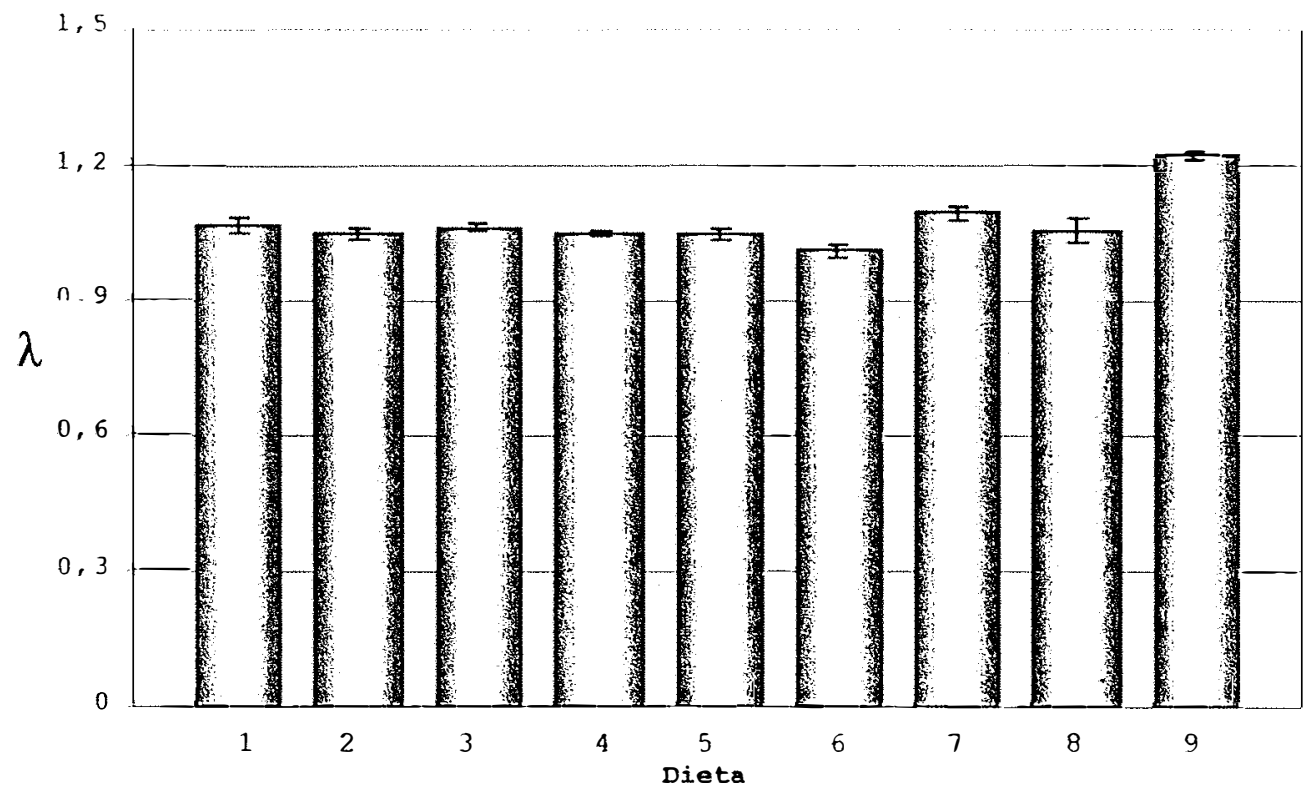

(*)D1:Dieta de Greene et al.(1976) com feijăo Branco; D2: Dieta de Greene.et.al.(1976) com feijão 'Carioca'; D3: Dieta de Greene et al.(1976) com feijão 'Emgopa Ouro'; D4: Dieta de Greene et al.(1976) com feijåo 'Aeté'; D5: Dieta de Greene et al.(1976) com feijăo 'Jalo'; D6: Dieta de Greene et al.(1976) com feijăo 'Pintado'; D7: Dieta de Greene et al.(1976) com feijăo Branco + pó de folha de folha de tomateiro 'Santa Clara'; D8: Dieta de Greene et al. (1976) com feijåo Branco + extrato de folha de tomateiro 'Santa Clara; D9: folha de tomateiro 'Santa Clara'.

Figura 15 Razão finita de aumento populacional $(\lambda)$ de $T$. absoluta criada em 8 dietas artificiais e em dieta natural. As barras $(\perp$ e T) representam 0 intervalo de confiança de 95\%. Temperatura: $25 \pm 1{ }^{\circ} \mathrm{C} ;$ UR: $70 \pm 10 \%$; fotofase: $14 \mathrm{~h}$. 
O tempo de duplicação da geração

representa o período que as fêmeas levaram para duplicar o número de indivíduos em relação à população inicial do experimento. Para as fêmeas que se alimentaram de folhas de tomateiro, este tempo de duplicação foi de 3,48 dias, enquanto que para aquelas alimentadas com dieta artificial este período foi maior. (Tabela 19 e Figura 16).

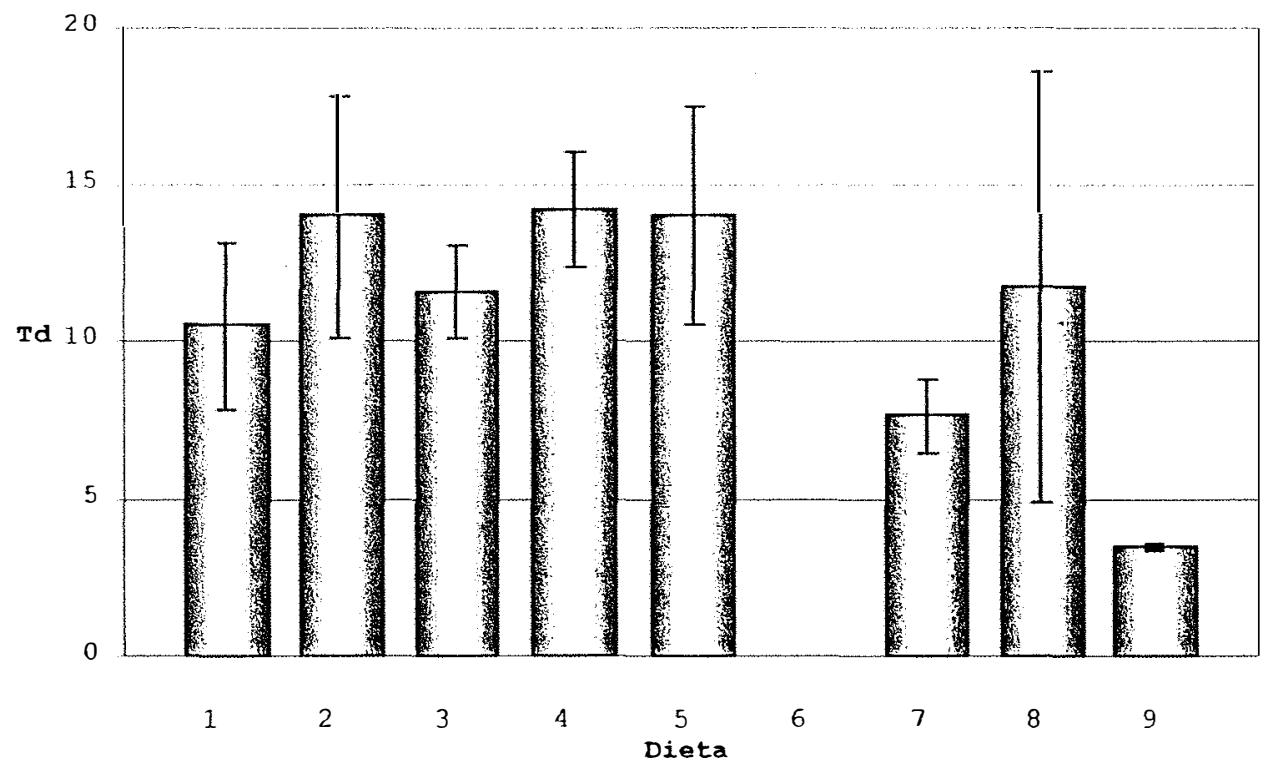

(*)D1:Dieta de Greene et al.(1976) com feijão Branco; D2: Dieta de Greene et al.(1976) com feijão 'Carioca'; D3: Dieta de Greene et al.(1976) com feijão 'Emgopa Ouro'; D4: Dieta de Greene et al.(1976) com feijão 'Aeté'; D5: Dieta de Greene et al.(1976) com feijão 'Jalo'; D6: Dieta de Greene et al.(1976) com feijão 'Pintado'; D7: Dieta de Greene et al.(1976) com feijão Branco + pó de folha de folha de tomateiro 'Santa Clara'; D8: Dieta de Greene et al.(1976) com feijão Branco + extrato de folha de tomateiro 'Santa Clara; D9: folha de tomateiro 'Santa Clara'.

Eigura 16 Tempo de duplicação de gerações (Td) de T. absoluta criada em 8 dietas artificiais e em dieta natural. As barras $(\perp$ e $T)$ representam $O$ intervalo de confiança de $95 \%$. T: $25 \pm 1^{\circ} \mathrm{C} ;$ UR: $70 \pm 10 \% ;$ fotofase: $14 \mathrm{~h}$. 
O menor valor de Td encontrado, em dietas artificiais, foi para àquelas fêmeas criadas em dieta de feijão Branco acrescido de pó de folha de tomateiro $(7,62$ dias) e o maior para aquela contendo feijão Áeté' $(14,17$ dias). Para a dieta contendo feijão 'Pintado' não foi possível calcular o valor do tempo de duplicação pelo método empregado. (Tabela 19 e Eigura 16).

Considerando-se as vantagens de se criar os insetos em dietas artificiais, especialmente pela possibilidade de tê-los disponíveis em qualquer época do ano, sugerem-se pesquisas no sentido de se melhorar, principalmente, as características físicas da dieta, que ao lado da adaptação ao laboratório, através de sucessivas gerações, permitirão que os resultados possam ser comparáveis àqueles obtidos em folhas de tomateiro.

\subsection{Local alternativo de postura de T. absoluta}

No tratamento em que se associou um estímulo olfativo (extrato de folhas de tomateiro) a um visual (polietileno verde), obteve-se o maior número de ovos, podendo este ser empregado como local alternativo do oviposição, já que o resultado obtido assemelha-se àquele registrado nas folhas de tomateiro, que é o substrato normalmente utilizado para oviposição (Tabela 20)

A descoberta de um local alternativo de postura é de grande importância, quando se pensa em manutenção de criações em larga escala, pois há necessidade 
de se ter um elevado número de ovos, com alta viabilidade e facilmente coletados.

Tabela 20: Número médio de ovos por fêmea de Tuta absoluta criada em dieta artificial em a diferentes

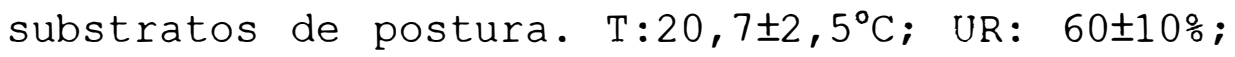
fotofase: $14 \mathrm{~h}$.

\begin{tabular}{|c|c|c|c|}
\hline \multirow{2}{*}{ Tratamento } & \multirow{2}{*}{$\begin{array}{l}\text { Número médio de } \\
\text { ovos / fêmea (*) }\end{array}$} & \multicolumn{2}{|c|}{ I.C. $(5 \%)(\star \star)$} \\
\hline & & LS & $\mathrm{LI}$ \\
\hline $\begin{array}{l}\text { Papel sulfite }+ \text { extrato } \\
\text { de folha }\end{array}$ & $58,08 \pm 12.41$ & 86.12 & 30.04 \\
\hline $\begin{array}{l}\text { Papel sulfite }+ \text { extrato } \\
\text { de folha }+ \text { plástico verde }\end{array}$ & $144,62 \pm 15.60 \mathrm{a}$ & 179.89 & 109.35 \\
\hline $\begin{array}{l}\text { Papel sulfite }+ \text { fatia do } \\
\text { fruto do tomateiro }+\end{array}$ & $82,32 \pm 16.39$ & 119.35 & 45.29 \\
\hline plástico verde & & & \\
\hline $\begin{array}{l}\text { Papel sulfite }+ \text { fatia do } \\
\text { fruto do tomateiro }\end{array}$ & $71,60 \pm 10.12$ & 94.48 & 48.72 \\
\hline Papel sulfite & $72,87 \pm 16.16 \mathrm{bc}$ & 109.40 & 36.34 \\
\hline $\begin{array}{l}\text { Eolha de tomateiro 'Santa } \\
\text { Clara' (testemunha) }\end{array}$ & $130,08 \pm 11.23 \mathrm{ab}$ & 155.45 & 104.71 \\
\hline
\end{tabular}

(*)Médias seguidas da mesma letra, na coluna, não diferem entre si pelo teste de Tukey, no nível de 5\% de probabilidade;

(**) I.C.: Intervalo de confiança, LI: limite inferior, LS: limite superior.

Assim, Parra et al. (1995) trabalhando com Phtheochroa cranaodes Meyrick, relataram a preferência 
deste tortricídeo pela oviposição em plástico transparente colocado sobre um papel verde, apresentando os ovos uma alta viabilidade e não havendo alteração no comportamento de inseto. Os autores referem-se, ainda, à facilidade na coleta de ovos, pois basta recortar os pedaços de plástico contendo ovos. Na presente pesquisa, a traça-do-tomateiro também apresentou preferência pela oviposição em polietileno verde liso que o cobria papel sulfite branco umedecido com extrato de folha de tomateiro, apesar de normalmente ovipositar nas folhas de tomateiro que são bastante pilosas. Os ovos apresentavam alta viabilidade e não precisam ser retirados do polietileno. para que o período de incubação se complete.

Em todos os tratamentos, não se observou alteração no comportamento de oviposição, sendo os ovos colocados isoladamente ou em pequenas massas formadas por, no máximo, 10 ovos e todos de coloração amarelo-claro.

Os adultos que foram usados para a formação dos casais, nesta etapa da pesquisa, eram provenientes da criação da traça-do-tomateiro em dieta artificial selecionada no item 4.1, durante 3 gerações consecutivas. Pode-se notar que houve um aumento visível na capacidade de postura (Tabelas 6 e 20) da primeira etapa até esta etapa final, bem como na longevidade de adultos (Tabelas 7 e 21). Estes dois parâmetros demonstram que o inseto necessita de um período de adaptação ao meio artificial e que a alimentação por gerações sucessivas, é necessária para que possam ser obtidos resultados ainda mais favoráveis. 
A maior oviposição ocorreu nos primeiros dias após a emergência e acasalamento, decrescendo ao longo do período de sobrevivência.

Tabela 21: Longevidade média de machos de Tuta absoluta, obtidos de criação em dieta artificial e expostos a diferentes substratos de oviposição $\mathrm{T}: 20,7 \pm 2,5^{\circ} \mathrm{C} ;$ UR: $60 \pm 10 \%$; fotofase $: 14 \mathrm{~h}$.

Longevidade (dias)

Tratamento

Machos

Eêmeas

Papel sulfite + extrato de folha de tomateiro $28.83 \pm 2.46$ a $29,39 \pm 2.35 \mathrm{bc}$

Papel sulfite + extrato

de folha de tomateiro $+35.19 \pm 3.05$ a $34,19 \pm 2.49$ c plástico verde

Papel sulfite + fatia

do fruto do tomateiro $+31.57 \pm 2.56$ a $32.86 \pm 2.56$ c plástico verde

Papel sulfite + fatia do fruto do tomateiro $32.94 \pm 1.98$ a $24,41 \pm 2.27 \mathrm{ab}$ Papel sulfite $27.52 \pm 1.94$ a $25,65 \pm 1.95 \mathrm{abc}$

Folha de tomateiro

'Santa Clara' $30.00 \pm 3.18$ a $22,31 \pm 2.50$ a (testemunha)

Médias seguidas da mesma letra, na coluna, não diferem entre si pelo teste de Tukey, no nível de 5\% de probabilidade. 
A maior longevidade de machos $(35,19$ dias) foi observada no tratamento onde se associou o estímulo olfativo com o estímulo visual, ou seja, aquele conjunto formado pelo papel sulfite, plástico verde e extrato de folha de tomateiro (Tabela 21), valor este que não diferiu daquele obtido no tratamento com papel sulfite $(27,52$ dias). Para as fêmeas, no entanto, as diferenças na longevidade foram mais visíveis, pois aquelas do tratamento que envolvia papel sulfite, polietileno verde e extrato de folhas viveram, em média, 34,19 dias, enquanto que aquelas das folhas viveram menos $(22,31$ dias). Estes resultados evidenciam, mais uma vez, que há necessidade de um período de adaptação do inseto ao meio artificial, pois já na $3^{a}$ geração de criação sucessiva em dieta artificial, observaram-se longevidades e número de ovos sensivelmente maiores. Sugere-se a continuidade da pesquisa para que possa ser determinada a partir de que geração 0 inseto realmente está adaptado ao meio artificial. 


\section{CONCLUSÕES}

- A dieta natural, folhas de tomateiro da cultivar Santa Clara, é a mais adequada para criação de Tuta absoluta (Meyrick, 1917);

- É possível criar T. absoluta em dieta artificial;

- A adição de pó ou extrato de folha de tomateiro 'Santa Clara' tem efeito fagoestimulante para $T$. absoluta;

- A dieta artificial contendo germe-detrigo, farelo-de-soja, caseina, levedura-de-cerveja e feijão Branco, com adição de pó de folha de tomateiro 'Santa Clara', é a mais promissora para a criação de $T$. absoluta em laboratório;

- T. absoluta adapta-se às dietas artificiais ao longo das gerações;

- O número de ínstares, constante e igual a 4 em dieta natural e artificiais, indica a adequação nutricional e possibilidade de uso de dietas artificiais para criação de T. absoluta; 
- A faixa de temperatura mais adequada para a criação de T. absoluta em laboratório está entre 18 e $25^{\circ} \mathrm{C}$;

- Baseando-se nas exigências térmicas de T.

absoluta, podem ocorrer de 5,82 a 8,99 gerações/ano no Estado de São Paulo, em regiões com isotermas entre 20 e $25^{\circ} \mathrm{C}$

- Baseando-se na tabela de vida de fertilidade, a dieta natural ffolhas de tomateiro 'santa Clara') é a mais adequada para a criação de T. absoluta e, dentre as dietas artificiais, destaca-se aquela contendo feijão Branco acrescido de pó de folha de tomateiro;

- O papel sulfite com atraente visual (polietileno verde) e olfativo (extrato de folhas) pode substituir as folhas de tomateiro como local de postura de T. absoluta. 


\section{REFERÊNCIAS BIBLIOGRÁFICAS}

BAHAMONDES, L.A.; MALLEA, A.R. Biologia en Mendoza de Scrobipalpula absoluta (Meyrick) Povolny (LepidopteraGelechiidae), espécie nueva para la Republica Argentina. Revista de la Facultade de Ciências Agrárias, v.15, n.1, p.96-104, 1969.

BENTACOURT, C.M.; SCATONI, I.B.; RODRf́gUEZ, J.J. Influencia de la temperatura sobre la reproducción e el desarrollo de Scrobipalpuloides absoluta (Meyrick) (Lepidoptera, Gelechiidae). Revista Brasileira de Biologia, v.56, n.4, p.661-670, 1996.

BLEICHER, E.; PARRA， J.R.P. Espécies de Trichogramma parasitóides de Alabama argillacea. III. Determinação das exigências térmicas de três populações. Pesquisa Agropecuária Brasileira, v.25, n.2, p.215-219, 1990.

BUTT, B.A. \& CANTU, E. Sex determination of lepidopterous pupae. Washington: USDA, 7p., 1962. 
CARBALLO, R.; BASSO, C.; SCATONI, I.; COMOTTO, F. Ensayo para el control de Scrobipalpula absoluta (Meyrick) temporada de 1980-81. Revista Técnica, v.50, p.41-46, 1981 .

COELHO, M.C.F.; ERANÇA, F.H. Biologia e quetotaxia da larva e descrição da pupa e adulto da traça-do-tomateiro. Pesquisa Agropecuária Brasileira, v.22, n.2, p.129-135, 1987 .

ESTAY, P.I. Nomenclatur entomologicus. Informativo da Sociedade Entomológica do Brasil, v.21, n.2, p.2, 1996.

FERREIRA, J.A.M.; ANJOS, N. Caracterização dos ínstares larvais de Tuta absoluta (Meyrick) (Lepidoptera: Gelechiidae) In: CONGRESSO BRASILEIRO DE ENTOMOLOGIA, 16., Salvador, 1997. Resumos. Salvador: SEB, 1997. p.64

ERANÇA, F.H., MALUF, W.R., ROSSI, P.E.F. et al. Avaliação e seleção em tomate visando resistência à traça-dotomateiro. In: CONGRESSO BRASILEIRO DE OLERICULTURA, 24.; REUNIÃO LATINO-AMERICANA DE OLERICULTURA, Jaboticabal, 1984. Resumos. Jaboticabal: FCAV, 1984. v.1, p. 143 . 
GIUSTOLIN, T.A.; VENDRAMIM, J.D.; PARRA, J.R.P. Determinação do número de instares larvais de Tuta absoluta (Meyrick) em dois genótipos de Lycopersicum spp. e duas temperaturas. In: CONGRESSO BRASILEIRO DE ENTOMOLOGIA, 16., Salvador, 1997. Resumos. Salvador: SEB, 1997 . p.326.

GIUSTOLIN, T.A.; VENDRAMIM, J.D.; PARRA, J.R.P. Desenvolvimento de uma dieta artificial para estudos do efeito de aleloquímicos sobre Scrobipalpuloides absoluta (Meyrick) Anais da Sociedade Entomológica do Brasil, v.24, n.2, p.265-272, 1995 .

GONÇALVES, C.R.; OLIVEIRA, A.; LIMA, A.F. Scrobipalpula absoluta (Meyrick) (Lepidoptera-Gelechiidae), uma nova broca do tomateiro no Estado do Rio de Janeiro. In: CONGRESSO BRASILEIRO DE ENTOMOLOGIA, 8., Brasília-DF, 1983. Resumos. Brasilia: SEB, 1983. p.73.

GRAVENA, S. Manejo integrado de pragas do tomateiro. In: CONGRESSO BRASILEIRO DE OLERICULTURA, 24.; REUNIÃO LATINO AMERICANA DE OLERICULTURA, 1., Jaboticabal, 1984. Proceedings. Jaboticabal: UNESP, F.C.A.V., 1984. p.129149 .

GREENE, G.L.; LEPPLA, N.C.; DICKERSON, W.A. Velvetbean caterpillar: a rearing procedure and artificial diet. Journal of Economic Entomology, v.69, n.4, p.487-488, 1975. 
GROPPO, A.G. A Scrobipalpula absoluta no tomate. Correio Agrícola, n.2, p.530, 1983.

HADDAD, M.; PARRA, J. R. P. Métodos para estimar os limites térmicos e a faixa ótima de desenvolvimento das diferentes fases do ciclo evolutivo de insetos. Piracicaba: EEALQ, 1984. 12p.

HAJI, E.N.P. Aspectos biológicos da traça do tomateiro e seu controle. Petrolina: EMBRAPA, CPATSA, 1984. 2p. (EMBRAPA. CPATSA. Comunicado Técnico, 13).

HAJI, F.N.P.; PARRA, J.R.P.; SILVA, J.P.; BATISTA, J.G. de S. Biologia da traça-do-tomateiro sob condições de laboratório. Pesquisa Agropecuária Brasileira, v.23, n.2, p.107-110, 1988 .

HERRERA, A. Insetos de la papa en cañete. Revista Peruana de Entomologia, v.6, n.1, p.5-7, 1963.

HULTING, E.L.; ORR, D.B.; OBRYCKI, J.J. A computer program for calculation and statistical comparison of intrinsic rates of increase and associate life table parameters. Florida Entomologist, v.73, n.4, p.601-612, 1990. 
IMENES, S.D.L.; UCHOA-EERNANDES, M.A., CAMPOS, T.B.; TAKEMATSU, A.P. Aspects biológicos e comportamentais da traça-do-tomateiro Scrobipalpula absoluta (Meyrick, 1917), (Lepidoptera-Gelechiidae) Arquivos do Instituto Biológico, v.57, n.1/2, p.63-68, 1990 .

MEYER, J.S.; INGERSOLL, C.G.; MCDONALD, L.L.; BOYCE, M.S. Estimating uncertainty in population growth rates: jackknife vs. bootstrap techniques. Ecology, v.67, n.5, p.1156-1166, 1986 .

MORAES, G.J.de; NORMANHA FILHO, J.A. Surto de Scrobipalpula absoluta (Meyrick) em tomateiro no trópico semi-árido. Pesquisa Agropecuária Brasileira, v.17, n.3, p. 503-504, 1982 .

MOREIRA, J.O.T.; LARA, E.M.; CHURATA-MASCA, M.G.C. Ocorrência de Scrobipalpula absoluta (Meyrick) (Lepidoptera-Gelechiidae) danificando tomate rasteiro em Jaboticabal-SP. In: CONGRESSO BRASILEIRO DE ENTOMOLOGIA, 7., Fortaleza, 1981. Resumos, Fortaleza: SEB, 1981. p. 58 . 
MUSZINSKI, T.; LAVENDOWSKI, L.M.; MASCHIO, L.M. de Constatação de Scrobipalpula absoluta (Meyrick, 1917) [Gnorimoschema absoluta] (Lepidoptera, Gelechiidae), como praga do tomateiro (Lycopersicon esculentum Mill.), no litoral do Paraná. Anais da Sociedade Entomológica do Brasil, v.11, n.2, p.291-292, 1982 .

NAKANO, O.; PAULO, A.D. As traças do tomateiro. Agroquímica, n.20, p.8-12, 1983.

PÁDUA, L.E.M.; PARRA, J.R.P.;ROSSI, M.M. 'Relationship between nutricional and thermal requirements of Trichogramma pretiosum Riley, 1879, reared on different hosts. In: INTERNATIONAL CONGRESS OF ENTOMOLOGY, 20, Firenze, 1996. Proceedings. Firenze: International Congress of Entomology, 1996. p. 329.

PARRA, J.R.P. Biologia comparada de Perileucoptera coffeella (Guérin-Méneville, 1842) (LepidopteraLyonetidae), visando ao seu zoneamento ecológico no Estado de São Paulo. Piracicaba, 1981. 106p. Tese (LivreDocência) - Escola Superior de Agricultura "Luiz de Queiroz", Universidade de São Paulo. 
PARRA, J.R.P. Consumo e utilização de alimentos por insetos. In: PANIZZI, A.R.; PARRA, J.R.P. (Ed.) Ecologia nutricional de insetos e suas implicações no manejo de pragas. São Paulo: Manole, 1991. cap.2, p.965

PARRA, J.R.P. Técnicas de criação de insetos para programas de controle biológico. Piracicaba: FEALQ, 1996. 137p.

PARRA, J.R.P.; CARVALHO, S.M. Biologia e nutrição quantitativa de Spodoptera frugiperda (J.E.'SMITH, 1797) em meios artificiais compostos de diferentes variedades de feijão. Anais da Sociedade Entomológica do Brasil, v.13, n.2, p.306-319, 1984 .

PARRA, J.R.P. \& HADDAD, M.L. Determinação do número de ínstares de insetos. Piracicaba: FEALQ, 1989. 49p.

PARRA, J.R.P.; EIRAS, A.E.; HADDAD, M.L.; VILELA, E.E.; KOVALESKI, A. Técnica de criação de Phtheochroa cranaodes Meyrick (Lepidoptera: Tortricidae) em dieta artificial. Revista Brasileira de Biologia, v.55, n.4, p. 537-543, 1995. 
PAULO, A.D. Época de ocorrência de Scrobipalpula absoluta (Meyrick) (Lepidoptera-Gelechiidae) na cultura de tomate (Lycopersicon esculentumi Mill.) e seu controle. Piracicaba, 1986. 70p. Dissertação (Mestrado) - Escola Superior de Agricultura "Luiz de Queiroz", Universidade de São Paulo.

PETERS, T.M.; BARBOSA, P. Influence of population density of size, fecundity, and developmental rate of insects in culture. Annual Review of Entomology, v.22, p.431-434, 1977 .

PIRES, L.M.; MARQUES, M.R. Aspectos biológicos de Scrobipalpuloides absoluta (Lepidoptera, Gelechiidae) e aprimoramento de sua criação através do armazenamento de ovos e pupas. In: CONGRESSO BRASILEIRO DE ENTOMOLOGIA, 16., Salvador, 1997. Resumos. Salvador: SEB, 1997. p. 102 .

POVOLNY, D. On three Neotropical species of Gnorimoschemini (Lepidoptera, Gelechiidae) mining Solanaceae. Acta Universitatis Agriculturae Facultas Agronomica, v.23, p.379-393, 1975.

POVOLNY, D. Gnorimoschemini of southern South America III: the scrobipalpuloid genera (Insecta, Lepidoptera: Gelechidae). Strenstrupia, v.13, n.1, p.1-91, 1987. 
PRATISOLI, D. Bioecologia de Trichogramma pretiosum Riley, 1879 nas traças Scrobipalpuloides absoluta (Meyrick, 1917) e Phthorimaea operculella (Zeller, 1873), em tomateiro. Piracicaba, 1995. 130p. Tese (Doutorado) Escola Superior de Agricultura "Luiz de Queiroz", Universidade de São Paulo.

QUIROZ, E.C. Nuevos antecedentes sobre la biología de la polilla del tomate, Scrobipalpula absoluta (Meyrick). Agricultura Técnica, v.36, n.2, p.82-86, 1976.

RABINOVICH, J.E. Ecologia de poblaciones animales. Washington: Secretaria General de la Organización de los Estados Americanos, 1978. 114p.

RAZURI, V.; VARGAS, E. Biologia e comportamiento de Scrobipalpula absoluta Meyrick ( Lep., Gelechiidae) en tomatera. Revista Peruana de Entomologia, v.18, n.1, p. 84-89, 1975 .

SALAS, J.; EERNANDES, S. Los minadores de la hoja del tomate. FONAIAP Divulga, v.2, n.18, p.21-22, 1985. 
SCARDINI, D.M.B.; FERREIRA, L.R.; GALVEAS, P.A.O. Ocorrência da traça do tomateiro Scrobipalpula absoluta (Meyr.) no Estado do Espírito Santo. In: CONGRESSO BRASILEIRO DE ENTOMOLOGIA, 8., Brasília, 1983. Resumos. Brasilia: SEB, 1983. p.72.

SGRILLO, R.B. A distribuição de Weibull, como modelo de sobrevivência de insetos. Ecossistema, v.7, p.9-13, 1982 .

SINGH, P. A general purpose laboratory diet mixture for rearing insects. Insect science and its Application, Elmsford, v.4, n.4, p.357-362, 1983.

SILVEIRA NETO, S.; NAKANO, O.; BARBIN, D.; VILLA NOVA, N.A. Manual de ecologia dos insetos. São Paulo: Agronômica Ceres, 1976. 419p.

SOUZA, J.C. de; REIS, P.R.; GOMES,J.M.; NACIF, A.P. ; SALGADO, L.O. Traça-do-tomateiro: histórico, reconhecimento, biologia, prejuízos e controle. Belo Horizonte: EPAMIG, 1983. 14p. (EPAMIG. Boletim, 2). 
UCHOA-EERNANDES, M.A.; DELLA LUCIA, T.M.C.; VILELA, E.E. Mating, oviposition and pupation of Scrobipalpuloides absoluta (Meyr.) (Lepidoptera: Gelechiidae). Anais da Sociedade Entomológica do Brasil, v.24, n.1, p.159-164, 1995 .

ÚLLE, J.A. Determinação do momento crítico de controle da traça do tomateiro Scrobipalpuloides absoluta (Meyrick) (Lepidoptera: Gelechiidae) Botucatu, 1996. 123p. Dissertação (Mestrado) - Eaculdade de Ciências Agronômicas - Campus de Botucatu, Universidade Estadual Paulista Júlio de Mesquita Filho.

VARGAS, H.C. Observaciones sobre la biologia y enemigos naturales de la polilla del tomate, Gnorimoschema absoluta (Meyrick) (Lep., Gelechiidae). Idesia, V.1, p. 75-110, 1970 .

VENDRAMIM, J.D.; GIUSTOLIN, T. A.; HADDAD, M.L. Biologia da traça-do-tomateiro Tuta absoluta (Meyrick) em duas espécies de Lycopersicum em laboratório e casa-devegetação. In: CONGRESSO BRASILEIRO DE ENTOMOLOGIA, 16., Salvador, 1997. Resumos. Salvador: SEB, 1996. p.326. 